\title{
Analysis of Human Factors Effects on the Safety of Transporting Radioactive Waste Materials
}

\author{
Technical Report
}

April 1989

\author{
Mark D. Abkowitz \\ Susan B. Abkowitz \\ Mark Lepofsky \\ prepared for
}

Office of Transportation Systems and Planning

Battelle Nuclear Systems Group

505 King Avenue

Columbus, Ohio 43201-2693

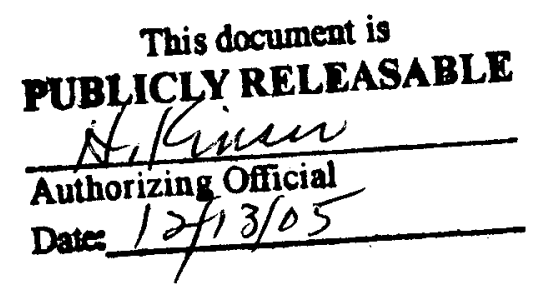

The content of this report was effective as of September 1988. This report was prepared by Battelle Nuclear Systems Group, Columbus, OH, under Contract No. DE-AC02-83CH10139 with the U.S. Department of Energy. 


\section{DISCLAIMER}

This report was prepared as an account of work sponsored by an agency of the United States Government. Neither the United States Government nor any agency Thereof, nor any of their employees, makes any warranty, express or implied, or assumes any legal liability or responsibility for the accuracy, completeness, or usefulness of any information, apparatus, product, or process disclosed, or represents that its use would not infringe privately owned rights. Reference herein to any specific commercial product, process, or service by trade name, trademark, manufacturer, or otherwise does not necessarily constitute or imply its endorsement, recommendation, or favoring by the United States Government or any agency thereof. The views and opinions of authors expressed herein do not necessarily state or reflect those of the United States Government or any agency thereof. 


\section{DISCLAIMER}

Portions of this document may be illegible in electronic image products. Images are produced from the best available original document. 
Th1s report exam1nes the extent of human factors effects on the safety of transporting radioactive waste materials. It is seen principally as a scoping effort, to establish whether there is a need for DOE to undertake a more formal approach to studying human factors in radloactive waste transport, and if so, logical directions for that program to follow.

Human factors effects are evaluated on driving and loading/transfer operations only. Particular emphasis is placed on the driving function, examining the relationship between human error and safety as it relates to the impalrment of driver performance. Although multi-modal in focus, the widespread availability of data and previous literature on truck operations resulted in a primary study focus on the trucking mode from the standpoint of pollcy development.

In addition to the analysis of human factors accident statistics, the report provides relevant background material on several policles that have been instituted or are under consideration, directed at 1mproving human rellability in the transport sector. On the basis of reported findings, preliminary policy emphasis areas are identified.

\section{DISCLAIMER}

This report was prepared as an account of work sponsored by an agency of the United States Government. Neither the United States Government nor any agency thereof, nor any of their employees, makes any warranty, express or implied, or assumes any legal liability or responsibility for the accuracy, completeness, or usefulness of any information, apparatus, product, or process disclosed, or represents that its use would not infringe privately owned rights. Reference herein to any specific commercial product, process, or service by trade name, trademark, manufacturer, or otherwise does not necessarily constitute or imply its endorsement, recommendation, or favoring by the United States Government or any agency thereof. The views and opinions of authors expressed herein do not necessarily state or reflect those of the United States Government or any agency thereof. 
The National Waste Terminal Storage Program was established 1n 1976 by the U.S. Department of Energy's predecessor, the Energy Research and Development Administration. In September 1983, this program became the Civilian Radioactive Waste Management (CRWM) Program. Its purpose is to develop technology and provide factlities for safe, environmentally acceptable, permanent disposal of high-level waste (HLW). HLW includes wastes from both comerclal and defense sources, such as spent (used) fuel from nuclear power reactors, accumulations of wastes from production of nuclear weapons, and solidifled wastes from fuel reprocessing.

The information in this report pertains to transportation studies within the Office of Storage and Transportation Systems in the CRWM Program. 
Th1s study was carrled out at the request of the Department of Energy's (DOE) Office of Civilian Radioactive Waste Management for the purpose of determining the extent of human factors effects on the safety of transporting radioactive waste materials. The intent of this effort was to establish whether there is a need for DOE to undertake a more formal program in the area of human factors 1n transportation, and if so, loglcal directlons for that program to follow. As such, it was envisioned as a scoping effort, directed at reporting of preliminary findings.

Although truck, rall and barge modes were considered in this analysis, a primary emphasis was placed on truck operations due to more widespread avallability of accident data and prior human factors studies focusing on the trucking 1ndustry. The study was also restricted to driving and loading/transfer operations. Unloading operations at a monitored retrievable storage factlity or geologic repository were assumed to constitute separate activities.

Several accident databases were obtained and reviewed for the purpose of exploring the relationship between human factors and accident characteristics. Unfortunately, since the historfcal database of transport accidents involving radfoactives was sufficlently small, commodity and contalner definftions had to be expanded to Include those which resemble radloactive waste shipments in order to Increase the sample size.

Concurrent with efforts to 1dentify and analyze relevant accident data, an extensive literature review was undertaken to search for previous studies related to human factors in transportation that might be relevant to the safe transport of radioactive wastes. As in the case of the database rev1ew, 1t became read1ly apparent that considerably more information is available on human factors in truck transport than for rall and barge operations.

From analyses of accident data, it is apparent that human error is a leading cause of accidents 1nvolving the transport of materlals in containers that resemble radioactive waste shipments. It can be inferred from these results that human factors effects on radioactive waste transport operations are likely to be signiflcant to the point where a more formal DOE human factors research program and program pollcles should be established. While one can argue over an apparent lower accldent severlty assoclated with human factors-related accldents, both loading and in-trans1t, the h1gh frequency of such events coupled with the public perception of a nuclear accident Independent of severity, suggests that the occurrence of these accidents should be kept to an absolute minimum.

Having established the scale of the human factors problem, attempts were made to obtaln more detalled information from which to identify significant or emerging human factors issues that might threaten the safety of radloactive waste shipments. The avallability of detafled truck accident data, coupled wth rather extensive outside 11terature on human factors in the trucking Industry, led to a decision to fully develop an understanding of these considerations for truck transport, with more limited attention devoted to rail and barge operations. 
Several findings can subsequenty be reported. It is apparent that the driver is most frequently the key factor in determining whether or not a vehicular accident occurs under dfficult driving conditions. A large number of heavy-truck drivers involved in accidents have poor driving records, Including speeding offenses and other unsafe maneuvers that are major causes of accidents. Moreover, the correlation between drivers under the influence of alcohol with increased accident likelihood and severity is a major safety concern.

Accident studies and drfver surveys also indicate that a major portion of the heavy-truck driver population has not recelved any driver training prior to going on the road. Young, Inexperfenced drfvers are particularly susceptible to accident risk.

Fatigue can play a major role in accidents, particularly for young drivers during early shift hours and older drivers after extended shift length. Drivers of large trucks have shown significant increases in driving errors and decreases in driver alertness due to fatigue well within the current hours-of-service 11mit. Greater understanding of the circadian rhythm (t1me-of-day) 1mpact on fatigue also suggests that current hours-of-service regulations and management assignment practices need additional examination.

Vehicle design and operating characteristics have a significant impact on the margin of safety within which human tasks must be performed. Brake systems are most in need of attention, with brake maintenance a principal concern. The prevention of fackknting also deserves special attention. Handling and stabllity problems increase the likelihood of rollover; t1re condition and performance are also key factors in safely handing a b1g r1g. Occurrences of override/underride, particularly at night, are common, suggesting that trafler design and visibility are issues that warrant close attention. Truck occupants typlcally do not protect themselves by wearing seat belts. As a result, ejection and contact with the cab interfor often occur, leading to a higher likelihood of a serfous infury or a fatality. Furthermore, truck operators are subjected to noise, vibration and other effects of prolonged truck driving which lead to performance degradation and health impairment.

The roadway environment 1 also recognized as a vital part of the safety equation. U.S. and State highways are significantly overinvolved in fatal heavy-truck accidents where the absence of sturdy median barriers has a profound 1mpact on safety. The need for cars and trucks to share the roads safely deserves attention. The driving public must be made more fully aware of the handling characteristics of heavy trucks and the potentlally iffe-threatening consequences of a multiple-vehtcle crash.

Although relatively little is known about human factors in rallroad and barge operations in comparison to the trucking industry, reported findings are remarkably consistent. Consequently, truck, rall and barge transport appear to share many comon human factors problems which may require policy intervention. 
In terms of container-related areas, these problems focus on securing valves, fittings and closures during the loading process, and making sure they remain snug throughout the in-transit portion of the trip; maintalning internal container pressure within safe limfts; safe handling of radloactive materials during the loading process; and proper protection of the shipment from damage should a vehfcular accident occur while In-transte.

The human tasks assoclated with the safe loading and transport of radloactive wastes require individuals who are responsible, qualified, and alert, with a positive attitude towards safety and a level of maturity commensurate with the hazardous nature of the materfal they are handing. It also requires a carrier management that has made a sincere commitment to safety in its operation, and has made every effort to comply with Federal safety regulation governing the transport of radloactive materlals. Finally, It requires a vehicle degign and operating environment that extends the margin of error so that when human errors occur, the opportunity to take a corrective action, can be made prior to an accident occurrence, thereby mitigating a potential accident or reducing the severfty of the ensuing accident.

Policy recomendations can be formulated which are directed at emphasis areas identified during the conduct of this study. These emphasis areas include the following: (1) employee selection and hiring practices, (2) drug and alcohol use, (3) fatigue, (4) speeding and other moving violations, (5) operator training, (6) vehfcle and environment factors, and (7) enforcement. 
TABLE OF CONTENTS

Page

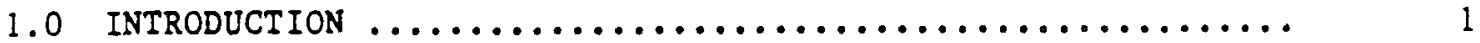

1.1 DEFINING HUMAN FACTORS IN TRANSPORTATION SAFETY ......

1.2 HUMAN FACTORS AREAS IN THE NUCLEAR WASTE TRANSPORT

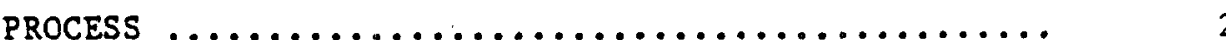

2.0 INFORMATION SOURCES FOR HUMAN FACTORS ANALYSIS $\ldots \ldots \ldots \ldots \ldots$

2.1 AVAILABILITY AND QUALITY OF ACCIDENT DATABASES ...... 7

2.1.1 Hazardous Materials Information System (HMIS).. 7

2.1.2 Nuclear Inc1dent Database .................. 10

2.1.3 National Accident Sampling System (NASS) ...... 10

2.1.4 Fatal Accldent Reporting System (FARS) ........ 11

2.1.5 Commercial Vessel Casualty File (CVCF).......... 11

2.1 .6 FRA Accident File ..................... 11

2.2 ANALYS IS METHODOLOGY $\ldots \ldots \ldots \ldots \ldots \ldots \ldots \ldots \ldots \ldots \ldots \ldots$ 11

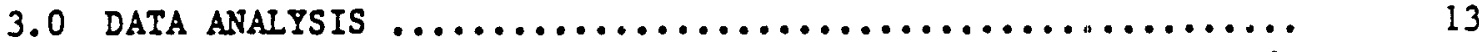

3.1 HUMAN ERROR AS A GENERAL ACCIDENT CAUSE ............ 15

3.2 MORE SPECIFIC ACCIDENT CHARACTERISTICS INVOLVING

HUMAN ERROR ............................ 20

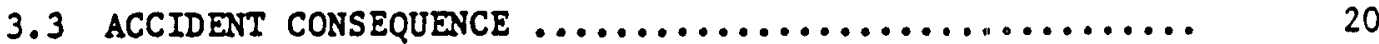

4.0 SIGNIFICANT OR EMERGING HUMAN FACTORS PROBLEMS .......... 31

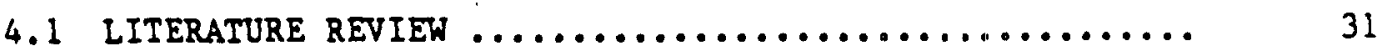

4.2 GUMAN FACTORS IN TRUCR SAFETY $\ldots \ldots \ldots \ldots \ldots \ldots \ldots \ldots \ldots . . \ldots \ldots$

4.2.1 Drfver Behavior ...................... 32

4.2.1.1 Driver Training ................ 32

4.2.1.2 On-the-Road Performance ........... 34

4.2.1.3 Previous Driving H1story .......... 37

4.2.1.4 Drugs and Alcohol ............... 37

4.2.1.5 Age and Experience .............. 40

4.2 .1 .6 Fat1gue ....................... 40

4.2.2 Vehicle Factors ..................... 45

4.2.2.1 Braking System ................. 48

4.2.2.2 Veh1cle Handling and Stability ....... 48

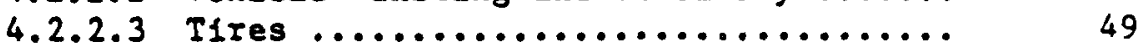

4.2.2.4 Overr1de/Underr1de ................ 49

4.2.2.5 Truck Occupant Protection .......... 49 
TABLE OF CONTENTS

(Continued)

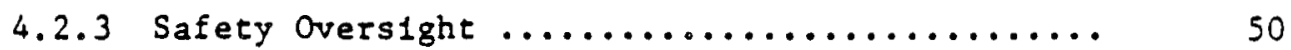

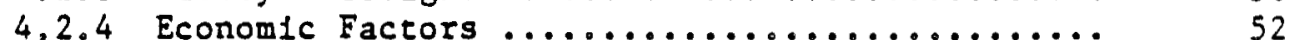

4.2.5 Roadway Environment Cons1derations .......... 53

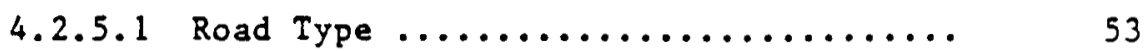

4.2 .5 .2 Lighting Conditions ............... 53

4.2.5.3 Sharing the Road ................ 56

4.2.6 Human Factors Polfcy Considerations for

Improving Truck Safety ................ 56

4.2.6.1 Driver Licensing .............. 57

4.2.6.2 Driver Selection .................. 58

4.2.6.3 Alcohol and Drug Use Among Prospective and Current Drivers ............ 59

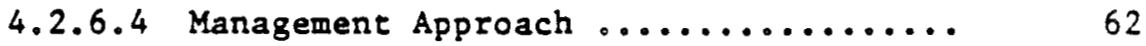

4.2.6.5 Driver Training ................ 63

4.2.6.6 Sharing the Road with the Driving

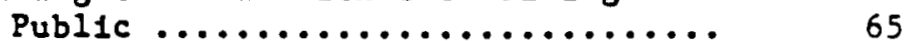

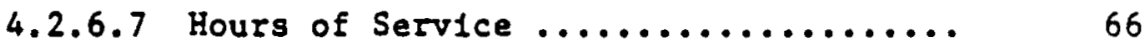

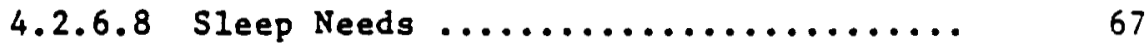

4.2.6.9 On-Board Recording Devices ........... 68

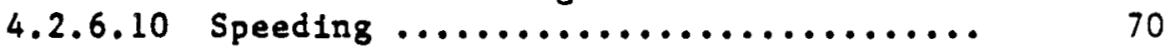

4.3 HUMAN FACTORS IN RAIL SAFETY ................. 70

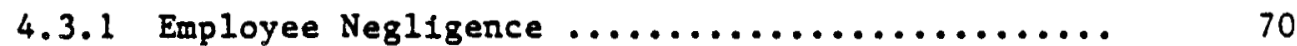

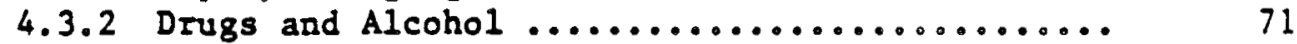

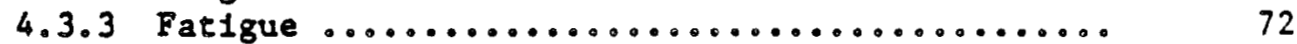

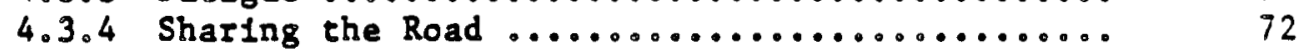

4.4 HUMAN FACTORS IN MARINE IRANSPORT $\ldots \ldots \ldots \ldots \ldots \ldots \ldots \ldots$.

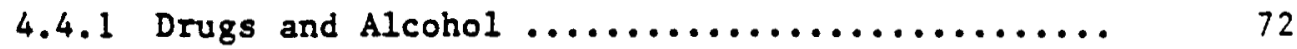

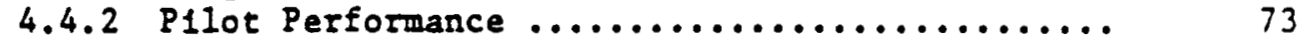

5.0 CONCLUSIONS AND POLICY RECOMENDATIONS ............... 75

5.1 POLICY RECOMMENDATIONS $\ldots \ldots \ldots \ldots \ldots \ldots \ldots \ldots \ldots \ldots \ldots \ldots$

5.1.1 Employee Selection and H1ring Pract1ces ....... 76

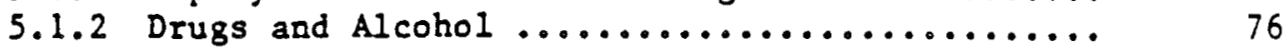

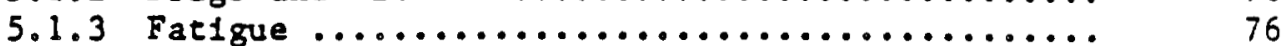

5.1 .4 Speeding and Other Moving Violations .......... 77

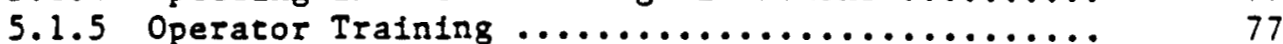

5.1.6 Vehicle and Environment Factors ............ 78

5.1.7 Enforcement ........................ 78 
TABLE OF CONTENTS

(Continued)

Page

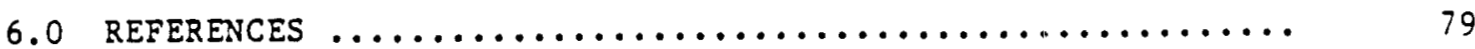

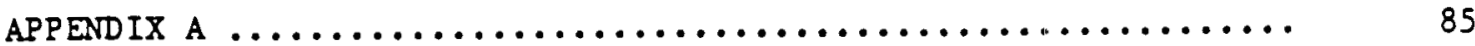

LIST OF TABLES

Table

Title

Page

1. Potent1al Accident Databases ...................

2. HMIS Sample Size by Contalner Class and General

Cause for Proxy Hazard Classes, 1980-87 ............

3. Contributing Circumstances to State of Washington

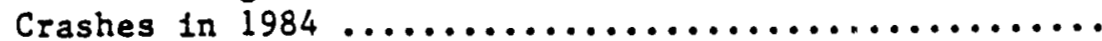

4. Interviews About Truck Cruising Speeds of

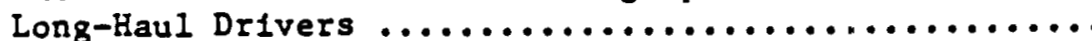

5. Single Trailer Vehicular Accident Involvement Rates

by H1ghway Functional Class ...................

LIST OF FIGURES

F1gure

Title

Page

1. Multiple Factor Accident Causation Model ...........

2. Human Information Processing Sequence .............

3. Hierarchy of Relevant Accident Information by Mode ...

4. Human Error as Loading Acc1dent Cause by Contalner Class for Proxy Hazard Classes ............

5. Human Error as In-Trans1t Accident Cause by Contalner Class for Proxy Hazard Classes ............

6. Primary Cause of Ra11 Accidents ................ 18

7. Primary Cause of Marine Preight Transport Accidents .. 19

8. Contalner Fallure Cause for Rall Tank Car Loading Accldents Involving Proxy Eazard Classes ........... 
9. Container Fallure Cause for Bulk Highway Loading

Accidents Involving Proxy Hazard Classes ...........

10. Container Fallure Cause for Other Loading Accldents

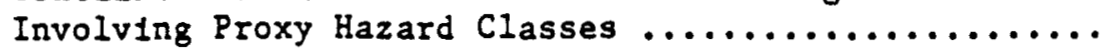

11. Conta1ner Fallure Cause for Ra1l Tank Car In-Transtt Accidents Involving Proxy Hazard Classes ...........

12. Contalner Faflure Cause for Bulk Highway In-Transit Accidents Involving Proxy Hazard Classes ............

13. Container Faflure Cause for Other In-Transit Accidents Involving Proxy hazard Classes ...........

14. Loading Accident Consequences by Contalner Class For Proxy Hazard Classes . . . . . . . . . . . . . . . . .

15. In-Trans1t Accident Consequences by Container Class

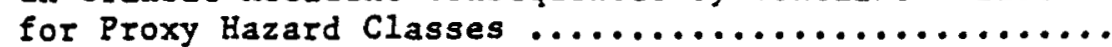

16. Driver Education of Accident-Involved Heavy-Truck Drtvers ..................................

17. Previous DrIving Records for Accldent-Involved Heavy-

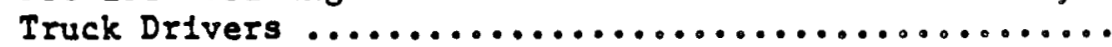

18. Effect of Heavy-Truck Driver Drinking Involvement

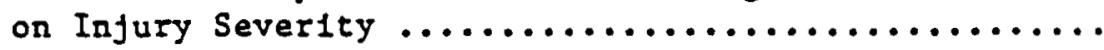

19. Drfver Age for Accldent-Involved Heavy-Truck

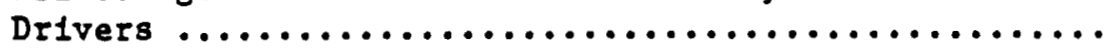

20. Truck Driver Activity Levels by Time of Day .........

21. Truck Driver Risk by Time of Day .............. 43

22. Truck Driver Risk and Duration of Activities ........ 44

23. Fat1gue and Non-Fatigue Classifled Truck Accldents

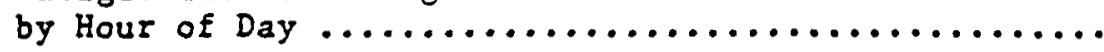

24. All Accident and Fatal Accident Involvements by Time of Day for Combination Trucks ............... 
TABLE OF CONTENTS

(Continued)

\section{LIST OF FIGURES}

Figure

Iftle

Page

25. Cal1fomia Truck Inspection and Truck Accident Rate for California State Highways (1976-1985) ............

26. Truck Accidents by Trafficway $\ldots \ldots \ldots \ldots \ldots \ldots \ldots$ 


\subsection{INTRODUCTION}

In response to growing public concern over the risk to public safety and the environment, Increased attention has been focused on the transport of hazardous materials. In analyzing incidents and accldents that have occurred during transport operations, several recent studies have indicated that "human error" is a primary cause (see, for example, Office of Technology Assessment, 1986). However, a detalled examination of more specific contributing factors and the extent to which regulation and enforcement can be modifled to decrease the likelihood of human error have not undergone extensive study.

Under the terms of the Nuclear Waste Polfcy Act (NWPA) of 1982, the U.S. Department of Energy's (DOE's) Office of Civllian Radioactive Waste Management (OCRWM) is responsible for transporting spent nuclear fuel and high-level radioactive waste from varfous generation and storage stes to a geologic repository. OCRWM has requested this study for the purpose of determining the extent of human factors effects on the safety of transporting radioactive waste materials. This profect addresses three principal questions:

1. Are human factors likely to be a mafor cause of radioactive waste transport incidents/accidents?

2. What are human factors-related incident/accident characteristics and are they distinguishable from other causation factors?

3. How can these problems be addressed in terms of policies and programs directed at radloactive waste transport?

Although truck, ra1l and barge modes were considered in this analysis, a primary emphasis was placed on truck and rall operations, due to their more likely utilization in repository shipments of radioactive waste.

It is 1mportant to note that this study is envisioned as a scoping effort only, to establish whether there is a need for DOE to undertake a more formal program in the area of human factors in transportation, and if so, logical directions for that program to follow.

In addressing transport safety, a distinction is often made between the terms "Incident" and "accldent." An 1ncident is defined as any unintentional release of a hazardous material during the transport process, including loading/unloading or temporary storage related to transportation. The term "accident" refers to a vehicular accident. Most hazardous materials transport incldents are not caused by vehfcular accidents (e.g., loose fitting). For simplic1ty sake, the term "accident" w1ll be used in this report to denote incldents and the term "vehicular accident" will be used when referring to crash circumstances.

\subsection{DEFINING HUMAN FACTORS IN TRANSPORTATION SAFETY}

In the transport of spent nuclear fuel or other complex technological systems, it is rather difficult to develop a consistent and universally accepted definition and 1dentification of "human error." This is due in part to the purpose of the analysis, disciplinary perspective, and organizational 
or social objectives (Tuler, et al., 1988). In this study, a rather loose definition has been applled, namely "human error" is the behavtor of a person transgressing the multidimensional bounds of acceptable performance (Sheridan, 1983). This approach is a rattonal one for considering transport operations, since the bounds of acceptable performance vary under normal and emergency conditions and include several criterta, such as technical and economic effictency, system rellability and public safety.

The occurrence of a transport accident due to human error is part of a complex process that results in an accident experience. These events are typlcally comprised of multiple factors that collectively form a causal system. The system components include operating personnel, the vehicle, and the operating environment; economlc and management factors can also be influential. The interrelationships of these factors are shown in Figure 1.

Normally, personnel, vehicle, and operating conditfons contribute to an environment where, under most circumstances, adequate safety can be maintained. When one or more of these parameters is subjected to a situation that exceeds the safety margin, an accident may occur. If the normal margin of safety is reduced because of unsafe industry practices, the frequency and severtty of accidents can be expected to increase.

Accident reports are often the basis for conducting safety analyses. However, these reports are limited in detall, and frequently the reported "cause" is the last and precipitating event in a chain of events. Thus, exploring accident information beyond a general level of detall is of critical Importance.

Th1s applies, in particular, to human error, often cited as a primary accident causation factor. For example, in truck transport, when reporting vehicular accidents, police are required to attribute responsibility to one of the parties. Many enforcement officers are not famlliar with the detalls of truck technology and overlook vehtcular accident factors that the truck driver was unable to cope with because of linitations in the truck's handing capabilities. Thus, enforcement offlcers may attribute responstbility to the driver in more instances than warranted. For example, in Californla, vehicular accident reports assoclate drfver error with over 90 percent of truck-at-fault accidents (Cal1fornia Highway Patrol, 1987). However, in the majority of cases, there are multiple causes, comonly involving driver error and defects in road design and the vehtcle (Fructus, 1987).

\subsection{HUMAN FACTORS AREAS IN THE NUCIEAR WASTE TRANSPORT PROCESS}

The transportation of radioactive waste involves a number of stages of activity which depend on relfable human performance. In a broad sense, this encompasses transportation system design, implementation, operations, maintenance and accident recovery. This study focuses exclustvely on transport operations, and more spectflcally on driving and loading/transfer operations. It excludes analysis of unloading accidents, as it is assumed that unloading operations at a monitored retrfevable storage facillty or geolugic repository constitute a separate activity.

Particular emphasts is placed on the driving function, examining the relationship between human error and safety as it relates to the impairment of 
Figure 1

Multiple Factor Accident Causation Model

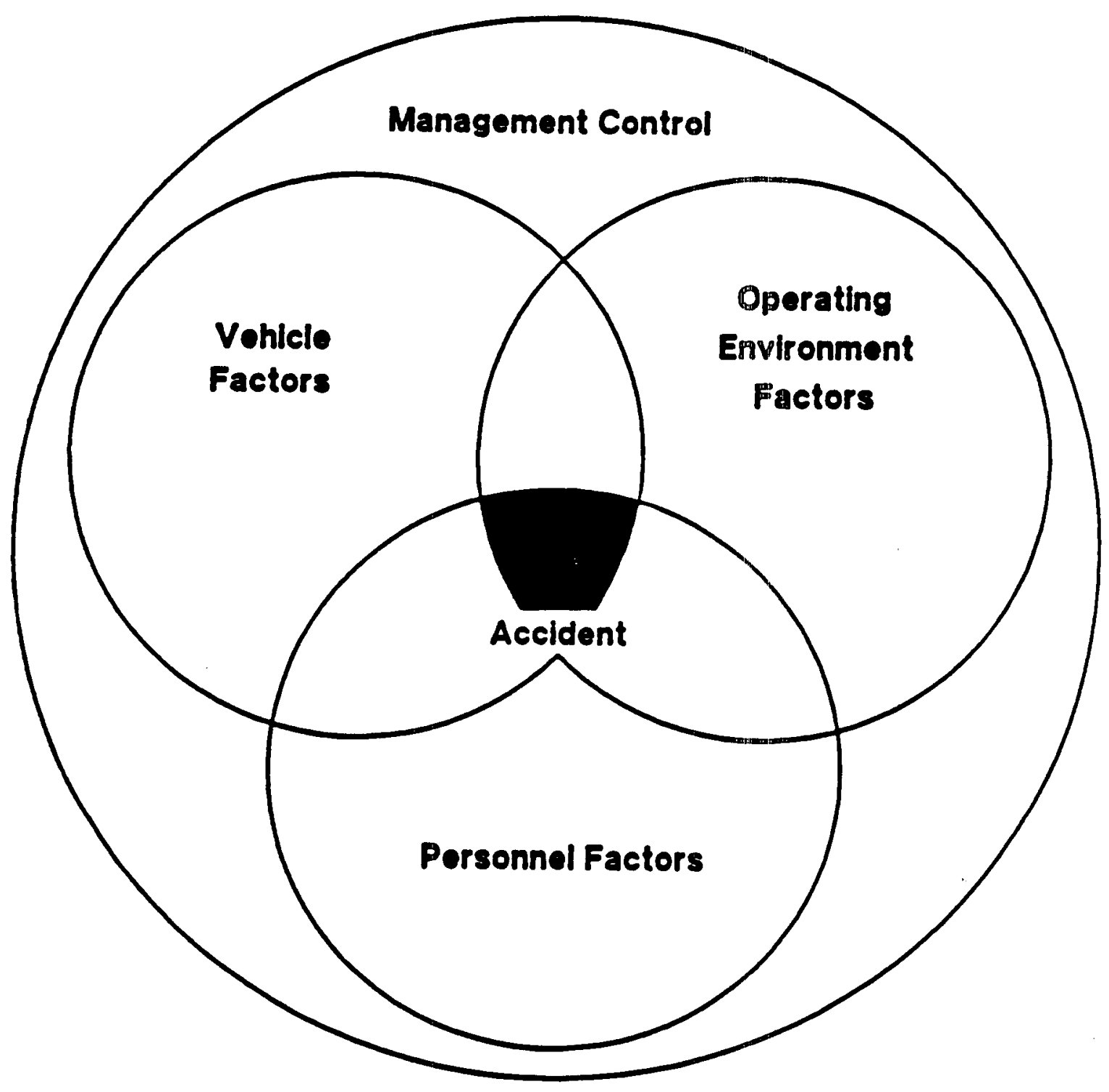

cemes: Alapted trem MuTre, 1098 
driver performance. As a preface to this discussion, it is useful to consider the processes at work when a human is placed in charge of an operating environment, such as behind the wheel of a commerclal rig, where information must be continually. processed and evasive actions taken. Figure 2 depicts a typical human information processing sequence. In essence, the driver is recelving new information, must recognize and evaluate $1 t$, reach a decision, and take a response action. Because of the continual change in the roadway environment and constraints on heavy-truck stopping capability and maneuverabillty, this suggests that a heavy-truck driver should be at the peak of alertness at all times, and have had sufficlent driving experience to maintain an adequate margin of safety. Any impalment or behavioral characteristic which alters the abllity to acknowledge information, perceive correctly, reach an informed decision and take a correspondingly safe driving action can seriously threaten safe driving performance.

An alert driver can execute the phases in Figure 2 in less than two seconds when confronted with an unexpected hazard in the roadway (Olson, 1984). However, given that even alert drivers have been shown to have only a single decision channel and therefore all information must be processed sequentially, the extent to which an 1mpaiment 1mpacts the timeliness with which a potential conflict is recognized and an abatement action, if any, is taken, is also an important consideration (Allnutt, 1983). 
Figure 2

Human Information Processing Sequence

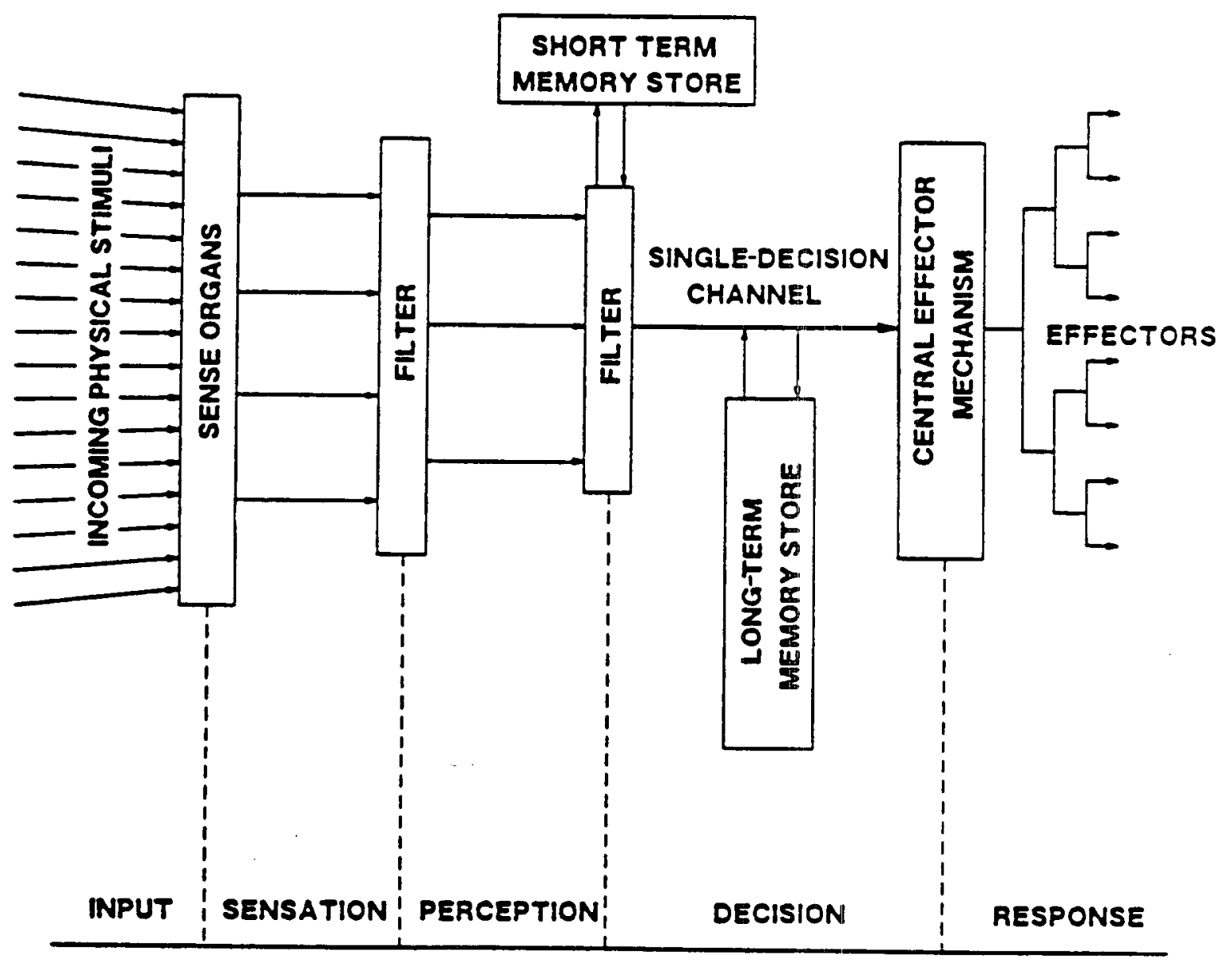

semes: Amute, 1809

$5 / 6$ 


\subsection{INFORMATION SOURCES FOR HUMAN FACTORS ANAIYSIS}

An essentlal component of safety measurement and evaluation is a complete and accurate database that contalns relevant accident statistics. The identification of factors contributing to accident causation and severity is central to the establishment of priorities for improvements and corrective actions.

\subsection{AVAILABILITY AND QUALITY OF ACCIDENT DATABASES}

From a safety analysis perspective, one would like to have an abundance of information on radioactive waste transport accldents, such that an empirical analysis could be undertaken whose results would be directly applicable. However, historically there have been relatively few radioactive waste accidents (and shipments), and there is not sufficient sample size from which to conduct rigorous statstical analysis on this basis.

The next most destrable option would be to restrict the analysis focus to all hazardous materlals accldents whose chemical qualities, packaging and release characteristics most resemble those found in the transport of nuclear waste. This effort was pursued in the course of this study in an attempt to reach a broad understanding of human error as a contributing factor.

More specific information on the characteristics of the accident is generally not avallable until one investigates vehicular accident reporting systems which focus on all frelght sargo. These databases of ten include a hazardous materlals flag, Indicating when an accldent involves a hazardous materlal, but the materlal itself is not usually specified. Thus, some segmentation of the data can take place as it relates to the study in question.

This approach results in the development of a hierarchy of relevant accident information as shown in Figure 3. An obvious tradeoff emerges in that if detalled human factors analysis is desired, dependence on more general vehicular accident data is necessary, and 1mplications on radioactive waste transport must be made by Inference.

A full discourse on hazardous materials transportation accident information systems (Including reporting criteria) appears in Appendix $A$, and is summarized in Table 1. A review of these sources was conducted as part of this study, resulting in the 1dentification of the following databases which were deemed potentlally relevant to the project objectlves. Each of these databases is described briefly below.

\subsubsection{Hazardous Materials Information System (HMIS)}

Malntalned by the U.S. Department of Transportation (DOT) in the office of Hazardous Materials Transport (OHMT), this database became the centralized Federal system for unfform accident data in 1971. As prescribed in the 49 CFR regulations, carrfers are required to report any unintentional release of a hazardous material during transportation, with the exception of consumer commodities which present only a limited hazard during transportation, 
Figure 3

Hierarchy of Relevant Accident Information by Mode
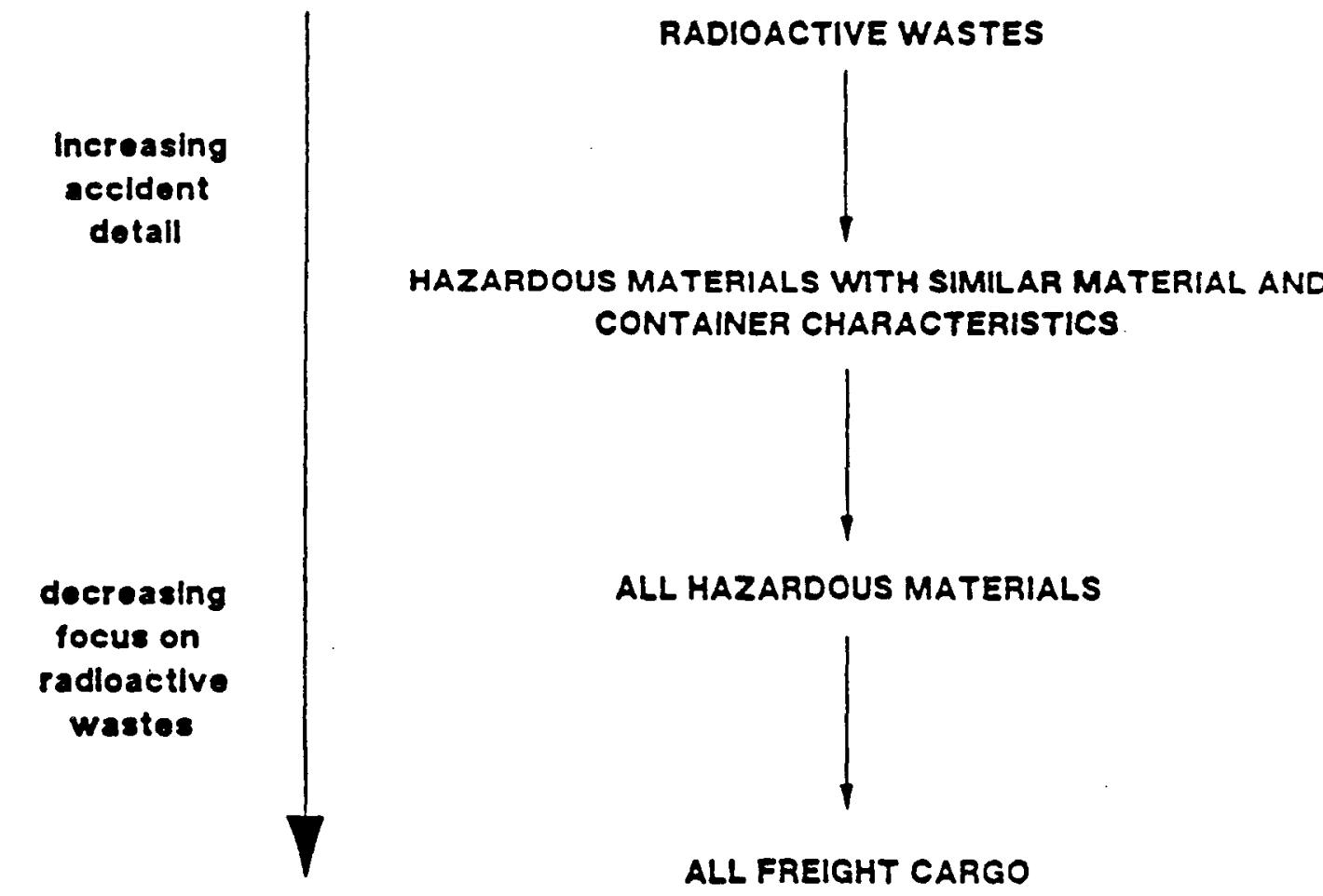

ALL FREIGHT CARGO 
Table 1. Potential Accident Databases

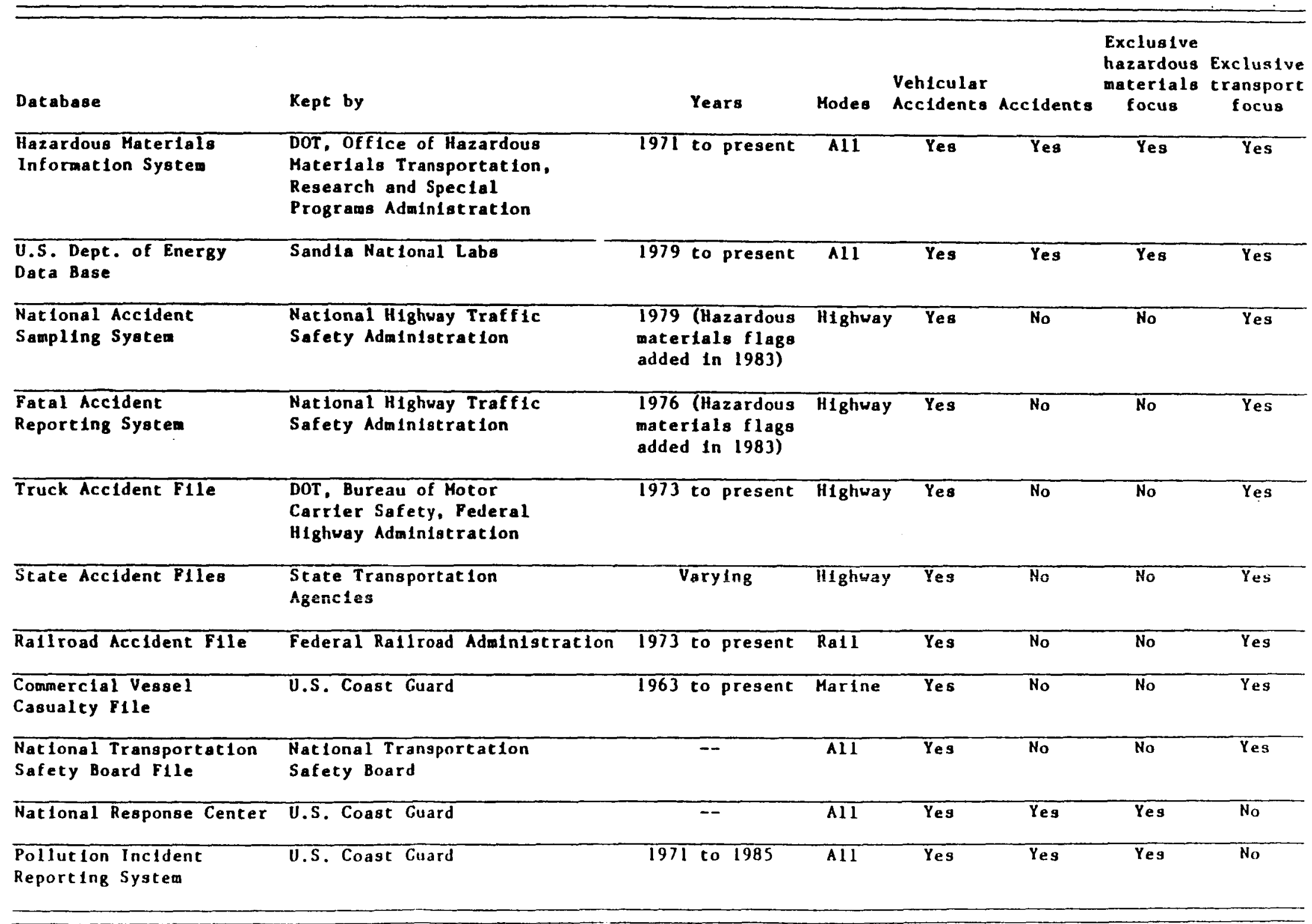


electric storage batterles, and certain paints and related materials (General Services Administration, 1984).

In many respects, the EMIS database serves as the most relevant database for conducting hazardous materials transport safety analysis. It represents the only system devoted exclusively to hazardous matertals transport accidents, and as such, it includes a number of descriptors that can be used to examine 1ssues in packaging, labeling, accident causation and public safety that might not otherwise be posstble.

Although spill reporting is a regulatory requirement, in practice it is handled on a voluntary basis, quite posstbly because of the small size of the DOT enforcement staff and the relatively minor penalties for non-reporting. It has been estimated that up to and perhaps more than $30-40 \%$ of reportable accldents are never reported (OTA, 1986). Other problems emanate from: (1) shippers and frelght forwarders not being required to submit accident reports, (2) reports are not required by OHMT for accidents involving bulk marine shipments, and (3) DOT has elected not to regulate carriers involved only in intrastate transportation.

If the deficlencies in the HMIS database are accepted as stated, the total volume of hazardous materlals transport accidents is clearly understated. However, for the purposes of deriving distributions of events, causes and consequences, and for some mult1-modal comparative analyses, as is the Intention of this study, the HMIS database may st1l1 be representative.

\subsubsection{Nuclear Inc1dent Database}

DOE maintains a database of all radioactive transportation accidents, based on the HMIS file and Information from the Nuclear Regulatory Comission on the loss of control of radioactives. The database consists of approximately $70 z$ HMIS records and 307 Nuclear Regulatory Comission records.

In the past, this database has been maintalned, on-Iine, at Sandia Labs. Recently, responsibllity for database management shffted to Oak Ridge National Laboratory, and then was moved back to Sandia aga1n. Because of the sudden change in management responsiblilty of this database, requests for data were not being handled during the time that this study was carried out.

\subsubsection{Nat1onal Acc1dent Sampling System (NASS)}

The National Highway Traffic Safety Administration (NHTSA) maintains vehlcular accident data on police reported accldents. The data is typically collected by each State under contractual agreement with NHTSA.

The file of reported vehicular accidents is called the National Accident Sampling System (NASS). The vehicular accidents investigated are a probability sample of all police-reported accldents in the United States. The data collection for a NASS-selected vehicular accident is very involved, and includes follow-up investigation of the characteristics of the accident, driver, occupants and vehicle. Although the specific comodity being carried is not described for truck accidents, sufficient information exists to track accidents which 1nvolved hazardous cargo (NHTSA, 1981a). 
Because of the accident detall contained in the NASS reports, this is seen as a primary database for analyzing human factors 1nvolving truck in-transit vehicular accidents.

\section{1 .4 Fatal Accldent Reporting System (FAP.S)}

Those vehfcular accldents which result in loss of human iffe are also classiffed separately by NETSA in the Fatal Accident Reporting System (FARS). FARS is not a national sample; rather, tt includes all fatal traffic accidents that are reported in the Unfted States (NHTSA, 1981b). Other than this distinction, however, the Information collected parallels the NASS data structure as described previously.

In the context of this effort, since FARS represents only the most severe of vehicular accidents, analyses of FARS data was constdered as a useful basis for comparison to NASS findings in assessing the relationship between human factors and accident severity.

\subsubsection{Commerclal Vessel Casualey File (CVCF)}

The Commercial Vessel Casualty File (CVCF) is maintained by the U.S. Coast Guard. It includes both domestic and forelgn vessel accidents occurring In U.S. waters, and domestic vessel accidents occurring in foreign waters. Fields in each record include vessel characteristics, event, cause, fatalities/1njurfes and monetary damage. Each accideat record also contalns spectfle vessel codes which indlcate whether hazardous cargo was involved (D.S. Coast Guard, 1984).

Unfortunately, the level of detafl present in the CVCF accident record for human factors anialyses is not of the caltber avallable in the NASS and FARS databases. Consequently, use of this database was restricted in this study to deriving general estimates of the frequency of vessel accidents attributable to human factors.

\subsubsection{FRA Acc1dent F1le}

The Federal Rallroad Administration (FRA) maintains its own accident database from information generated by rallroads, inspectors and OHMT. The database includes some general information on likely human error-related accidents and potential causal factors. The FRA Accident File was also restricted in its use to providing aggregate estimates of accidents due to human factors.

\subsection{ANALYSIS METHODOLOGY}

As noted in the previous discussion, although several databases have been 1dentifled that are potentlally relevant to the study of human factors effects on the safety of transporting radfoactive waste materlals, none have been designed for the speciffc purpose. of 1nvestigating human factors. Consequently, certain aspects of each of the databases are pertinent to this study, although in most cases their use is restricted to general estimates of 
the magnitude of the human factors problem, and fall short of providing input to the development of more spectfic programs and polictes.

The destre to focus on comodities and contafners which are simflar to those being used or under consideration for the transport of radloactive waste materials, coupled with an interest in isolating loading and in-transit accidents, necessitates extensive use of the HMIS database. There 1s simply no other historical accident database that can provide these insights, albeit that the HMIS database suffers from some data collection problems as described earlier.

The basis for 1dentifying human factors 1ssues at a level of detail that prompts discussion of explicit programs and policles appears to be restricted to truck 1n-transit activities. The NASS and FARS databases contain considerable accident information from which to delve into specific human factors questions, such as driver behavior, vehicle performance and operating conditions. Unfortunately, a simllar resource is not available for evaluating the rail and barge industries, as the FRA and CVCF files are not designed to address these considerations at an appropriate level of detail.

The subsequent result of the data search was to refine the focus of this Inftial human factors study to a general assessment of the scale of the human factors problem that could be expected in the radioactive waste transport Industry, with an 1dentification of more spectfic areas for DOE polfcy consideration that apply to truck transport. Of course,. there may be several areas where policles directed at truck transport could be transferable to the rail and barge industries.

Concurrent with efforts to identify and analyze relevant accident data, an extensive literature review was undertaken to search for previous studies related to human factors in transportation that might be relevant to the safe transport of radioactive wastes. As in the case of the database revfew, 1t became readily apparent that constderably more information is avallable on human factors in truck transport than for rall and barge operations. Findings from the 11 terature review are discussed in Chapter 4. 


\subsection{DATA ANALYSIS}

Using the HMIS database as the primary Information source, analyses were undertaken to address the question of whether human factors might be a likely cause of nuclear waste transport accidents, and whether human factors accldent characteristics are distinguishable from accidents caused by other factors.

Although the HMIS database dates back to 1971, a dec1sion was made to exclude pre-1980 accidents from the analysis so that containers in the database might be more reflective of container technology in place today while maintaining adequate sample size.*

The EMIS database classifles the comodity shipped by name as well as by hazard class. A review of the hazard class descriptions revealed that several classes contained materials whose chemfcal qualities and packaging had little in common with radioactive waste shipments. For example, inclusion of corrosive materfals would not be particularly relevant to the issue under study consideration. Because the radioactives accldent sample size by itself was too small, the following group of four hazard classes were ultimately selected as belng most representative of radfoactive waste movements, and the analysis was subsequently restricted to an examination of accidents involving these materials:

1. Radioactives

2. Combustible Liquids

3. Flammable Liquids

4. Flamable Compressed Gases

In the remalnder of this document, this group is referred to as the "proxy hazard classes."

Each accldent record in the HMIS database also includes a detailed container specification. Even within the proxy hazard classes, some containers did not have design characteristics with any simflarfties to those under consideration for radioactive waste transport. Furthermore, the distinctions between rall and truck container speclfications, as well as between radioactives and other hazardous cargo contalners are sufficlently different that they may warrant separate consideration. Consequently, within the proxy hazard classes, the following four mutually exclusive container categorles were defined for analysis purposes:

1. Ra11 Tank Cars

2. Radioactive Materfals Containers

3. Bulk Highway Shipments

4. Other Concalners

* 1980 was defined as the cutoff date based on discussions with Battelle staff engineers. 
A methodology for 1solating loading and in-transit accidents for the proxy hazard classes was also developed. Loading/unloading accldents were separated from in-transit accidents on the basis of detailed accident cause codes which were ldentifled as being elther more pertinent to loading or in-transte operations, respectively. Unloading accldents were subsequently removed from the database by searching and retaining only loading/unloading accidents that occurred at the shipment origin.

Table 2 shows the number of recorded accidents in the HMIS database for each analysis cell. It is rather evident from observing this table that the number of reported radioactive material accldents is quite small, particularly loading accidents. This also confirms the need to include the proxy hazard classes for analysis purposes.

Table 2. HMIS Sample S1ze by Container Class and General Cause for Proxy Hazard Classes, 1980-87

\section{HUMAN ERROR \\ OTHER THAN \\ Loading In-Transit \\ HUMAN ERROR \\ Loading In-Transit}

\begin{tabular}{lrrrr}
\hline Rall Tank Cars & 18 & 1,250 & 16 & 1,745 \\
Radioactive Material Containers & 5 & 8 & 1 & 29 \\
Bulk Highway Containers & 540 & 626 & 201 & 2,513 \\
Other & 2,165 & 6,672 & 126 & 10,659 \\
\hline
\end{tabular}

Source: HMIS data, 1980-87 


\subsection{HUMAN ERROR AS A GENERAI ACCIDENT CAUSE}

The HMIS accident record includes both a general cause code and more specific accident causation factors. Each recorded accident is classified according to one of the following four general causes:

1. Human Error

2. Contalner Fallure

3. Vehicle Accident

4. Other

This designation is made by the carrier when filing the accident report and is therefore subject to their interpretation. Furthermore, there may be some mis-classified accidents, since the categories are not mutually exclusive. For example, in the case where a vehicular accident is due to human error, the general cause could be attributed to one of two categorles. With these caveats in mind, the results reported below should be considered approximations of the scale of the human factors problem that might face the radioactive waste transport program.

Figure 4 depicts the frequency with which human error is reported as the general cause of loading accidents for the proxy hazard classes, segmented by container class. A couple of observations can be made from reviewing the results. In an absolute sense, human error 18 listed as the general accident cause the majortty of the time, irrespective of which contalner category is considered. In a relative sense, human error is more likely to be c1ted as the general cause for container fallure in other than the groups consldered most simflar to radioactive waste contalner transport. On the other hand, human error 18 cited in over $80 \%$ of specific radioactive material container fallures, although one must keep in mind the small sample size from which this statistic is derived.

Simflar general cause information for in-transit accidents appears in Figure 5. Here, human error is not cited as frequently as the primary accident cause, although it remains prominent and continues to dominate other accident factors in several instances.

At a mode-specific level, human error as a primary accident cause was investigated for rall and marlne transport, using the FRA Accident File and CVCF, respectively. In both instances, hazardous materials shipments were segmented from other shlpments to provide for a comparative basis. Figure 6 shows that human factors is the second leading cause of rall accidents both for hazardous and non-hazardous shipments. It is interesting to note that human factors are c1ted more frequently for non-hazardous shipments, suggesting the possibility that some additional care is exercised over the shipment of dangerous cargo as it relates to personnel involvement.

Flgure 7 presents a slightly different picture for marine transport, particularly if one combines "crew at fault" with "other personnel/vessel." The U.S. Coast Guard treats these separately in order to determine which crew is at fault during collisions, etc. It is interesting to note that when personnel are blamed, more often than not the other vessel is considered at fault, certainly a typlcal response when interviewing people in multiple-vehicle traffic accidents. Nevertheless, it appears that human 


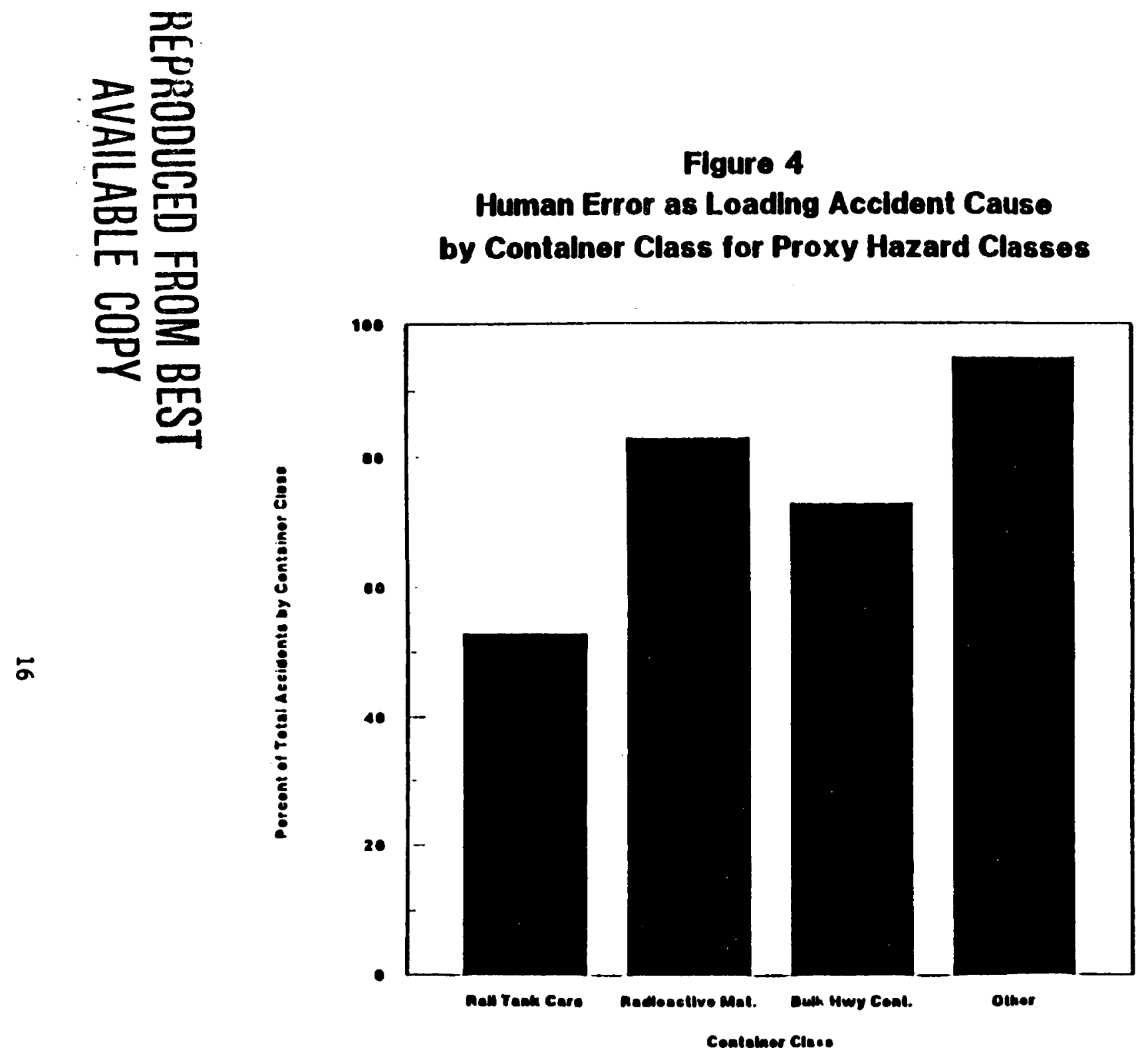

Soureo: Hams dolabese, 1000-at 
Figure 5

Human Error as In-Transit Accident Cause

by Contalner Class for Proxy Hazard Classes

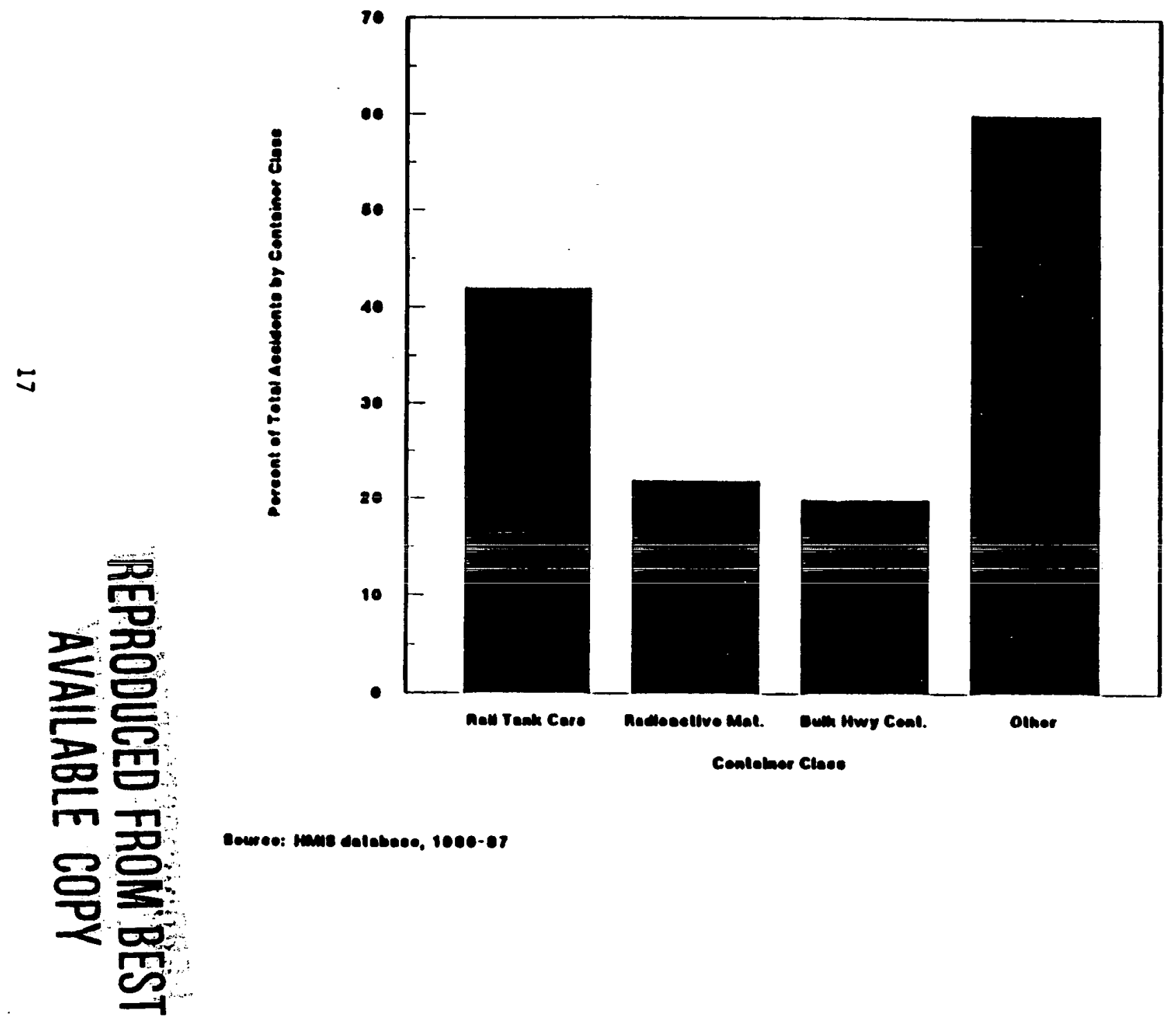




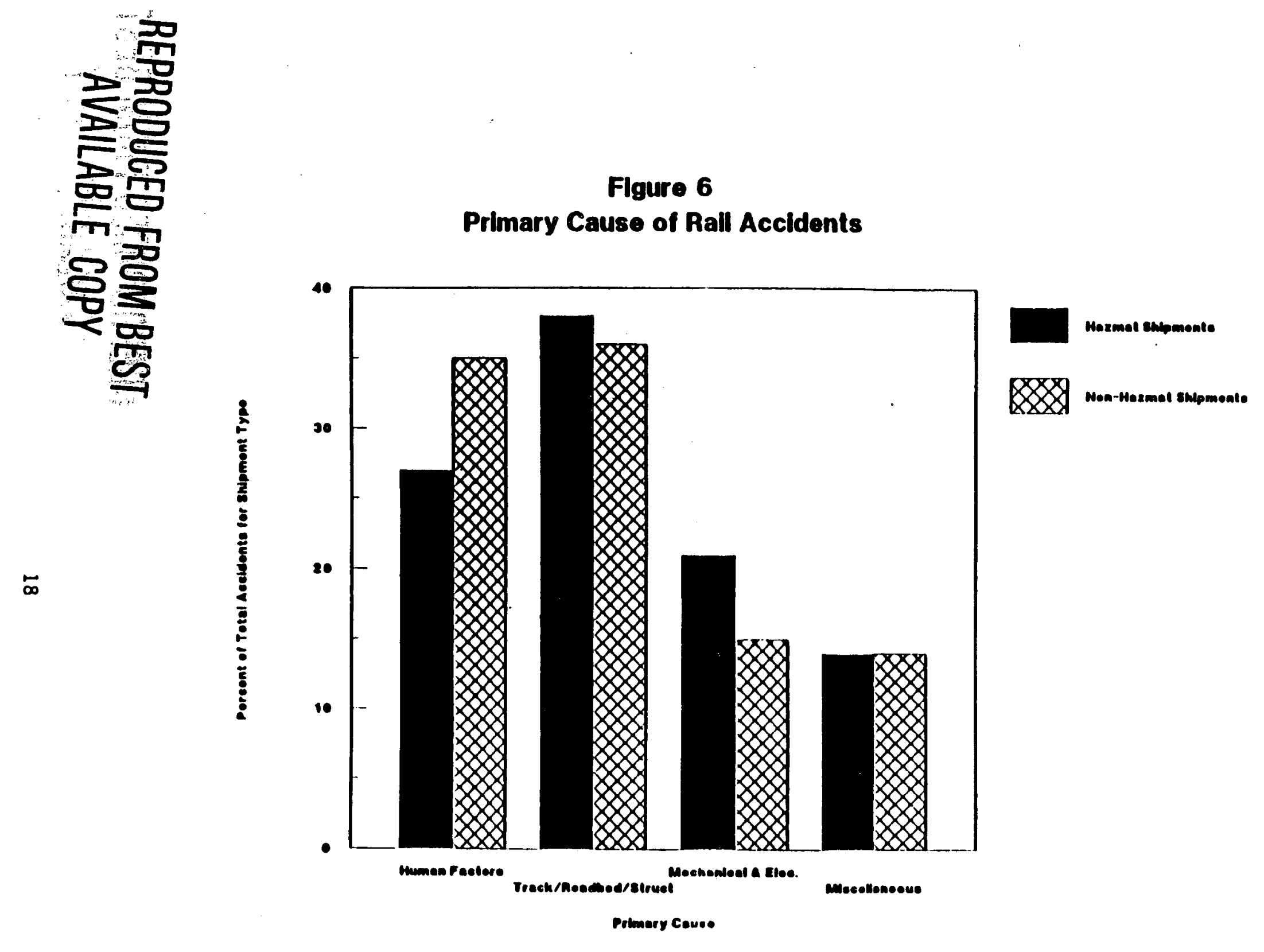


Figure 7

Primary Cause of Marine

Frolght Transport Accidents

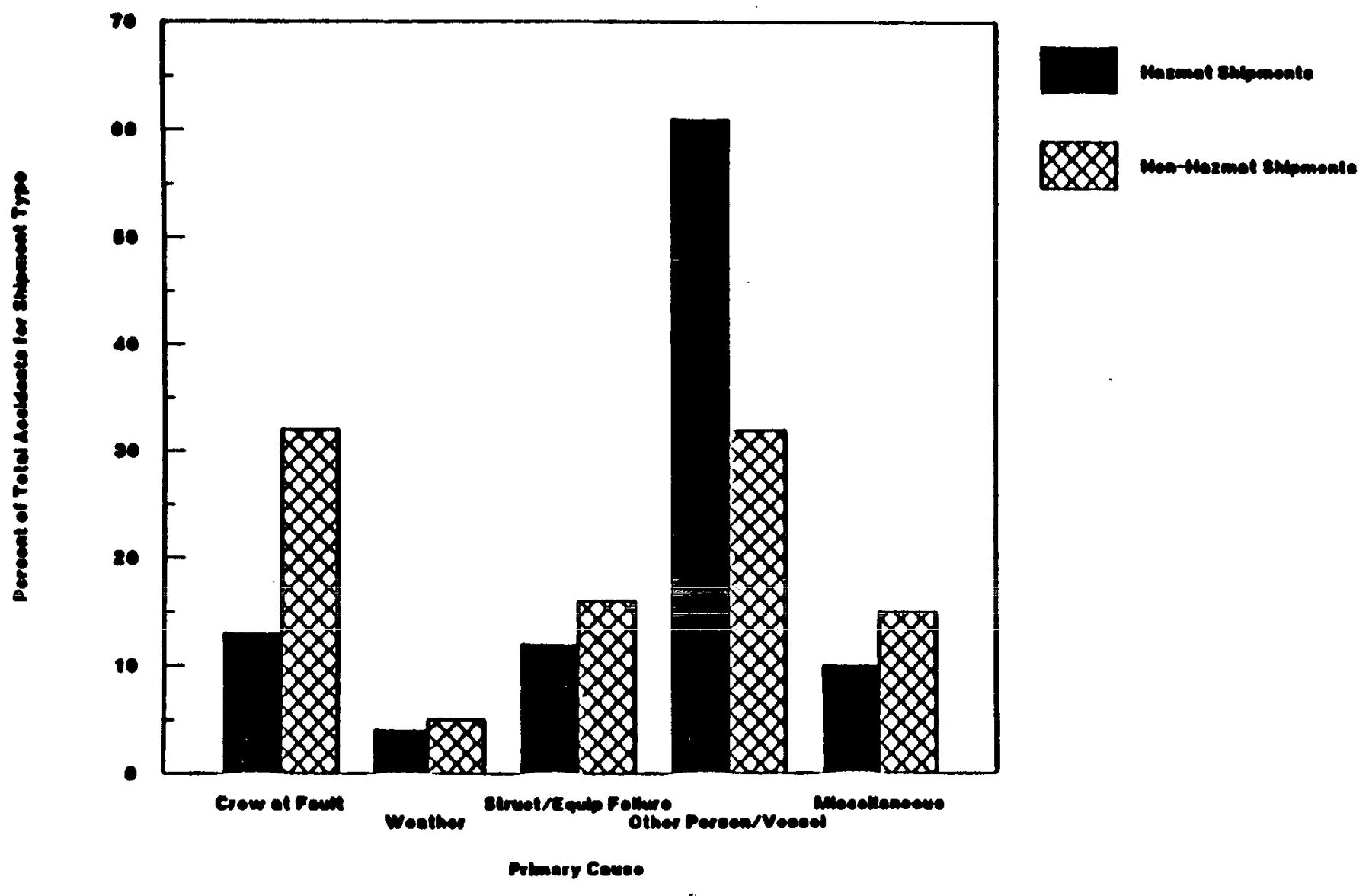

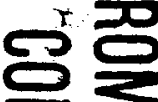

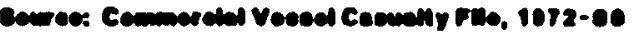

$<\infty$

药 
factors are the dominant cause for marine frelght transport accidents, although the distinction between hazardous and non-hazardous shipments is less clear because of the way in which the accident information has been recorded.

\subsection{MORE SPECIFIC ACCIDENT CHARACTERISTICS INVOLVING HUMAN ERROR}

In an attempt to focus more specifically on the human function which falled in accidents where human error was cited, analyses were conducted on the primary reason for container fallure using the HMIS database. Figures 8-13 present container fallure causes. for accidents involving proxy hazard classes, segmented by contalner categories and by whether the accident occurred during loading or while in-transit. The results in each figure are reported separately for accidents where human factors were cited as the general cause and for all other accidents.*

Several observations can be made from reviewing this material. First, for container types which most closely resemble nuclear waste transport shlpments, human error problems during the loading process focus on failure to secure fittings, valves and other contalner closures; improper blocking; and dropped during handling. Secondly, human error problems for container types which most resemble nuclear waste transport shipments during in-transit operations include releases from loose fittings, valves and closures; internal pressure; and external puncture, presumably due to contact between the container (tank car) and another object in crash scenarfos. The high frequency of reported human fallure to secure fittings, valves and closures as the cause of in-transit accldents clearly relates to the loading process. Internal pressure suggests the need to carefully monitor temperatire and pressure changes during transport. Puncture to the container during in-transit accidents suggests the need for proper securing, shielding and design protection of the casks in preparation for in-transit operations.

The reason for the rather large discrepancy between human factors problems for other shipments, both loading and in-transit, and those which most resemble radioactive waste shipments, is that many of the other commoditles are sent in smaller packages, of which several may be included in a single shipment. Consequently, there is a greater opportunity for a package to be dropped durlng handling or damaged by other frelght, perhaps due to Improper blocking.

\subsection{ACCIDENT CONSEQUENCE}

In addition to 1dentifying the frequency of occurrence of human factors-related accidents, it is also fmportant to examine the severity of such accidents. The average property damage per loading accident for proxy hazard classes is shown in Figure 14, segmented by container type and general

Figures do not appear for radioactive material contalners due to the small sample stzes lnvolved.

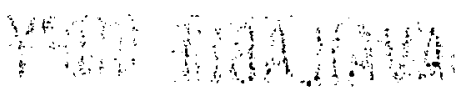


Flgure 8

Contalner Fallure Cause for Rall Tank Car

Loading Accidents Involving Proxy Hazard Classes

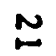

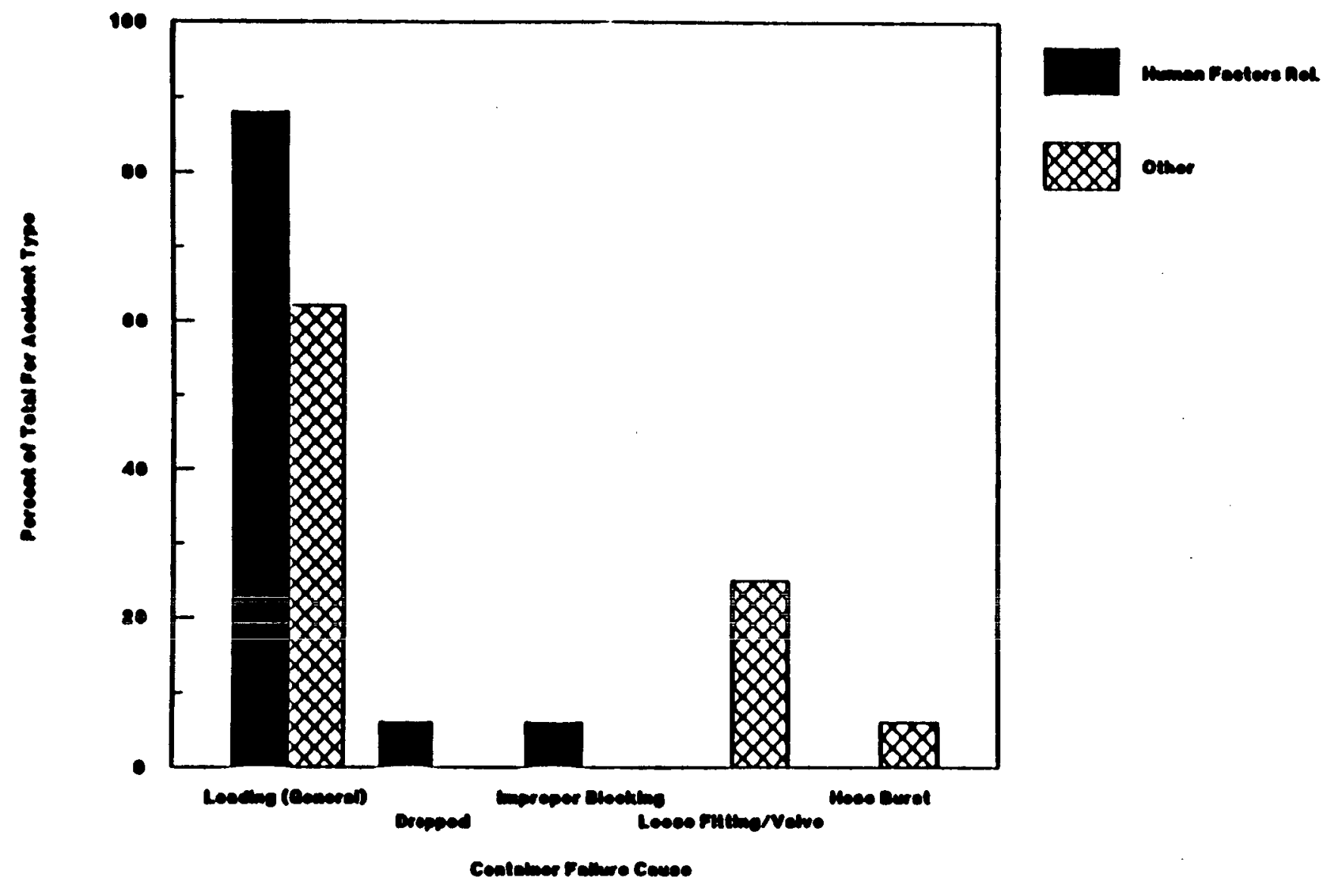

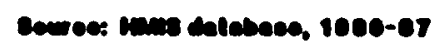




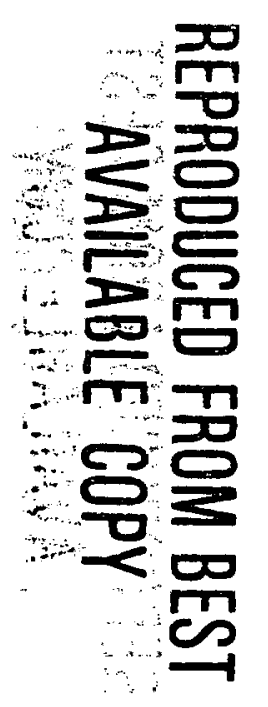

Figure 9

Contalner Fallure Cause for Bulk Hlghway Loading

Accidents Involuing Proxy Hazard Classes

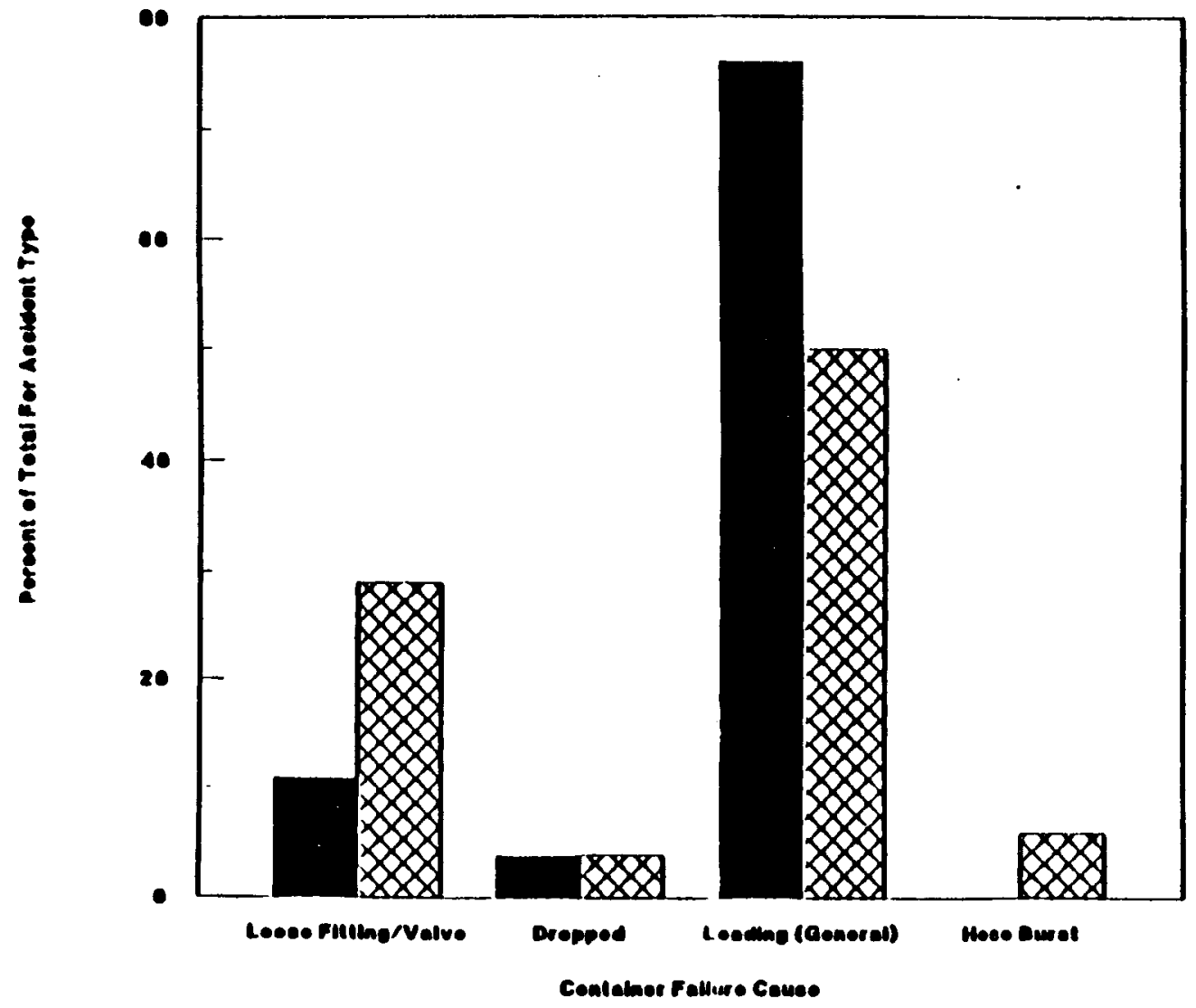

Mumea Fuelere hel.

X8X onor 
Figure 10

Contalner Fallure Cause for Other Loading

Accldents involving Proxy Hazard Classes

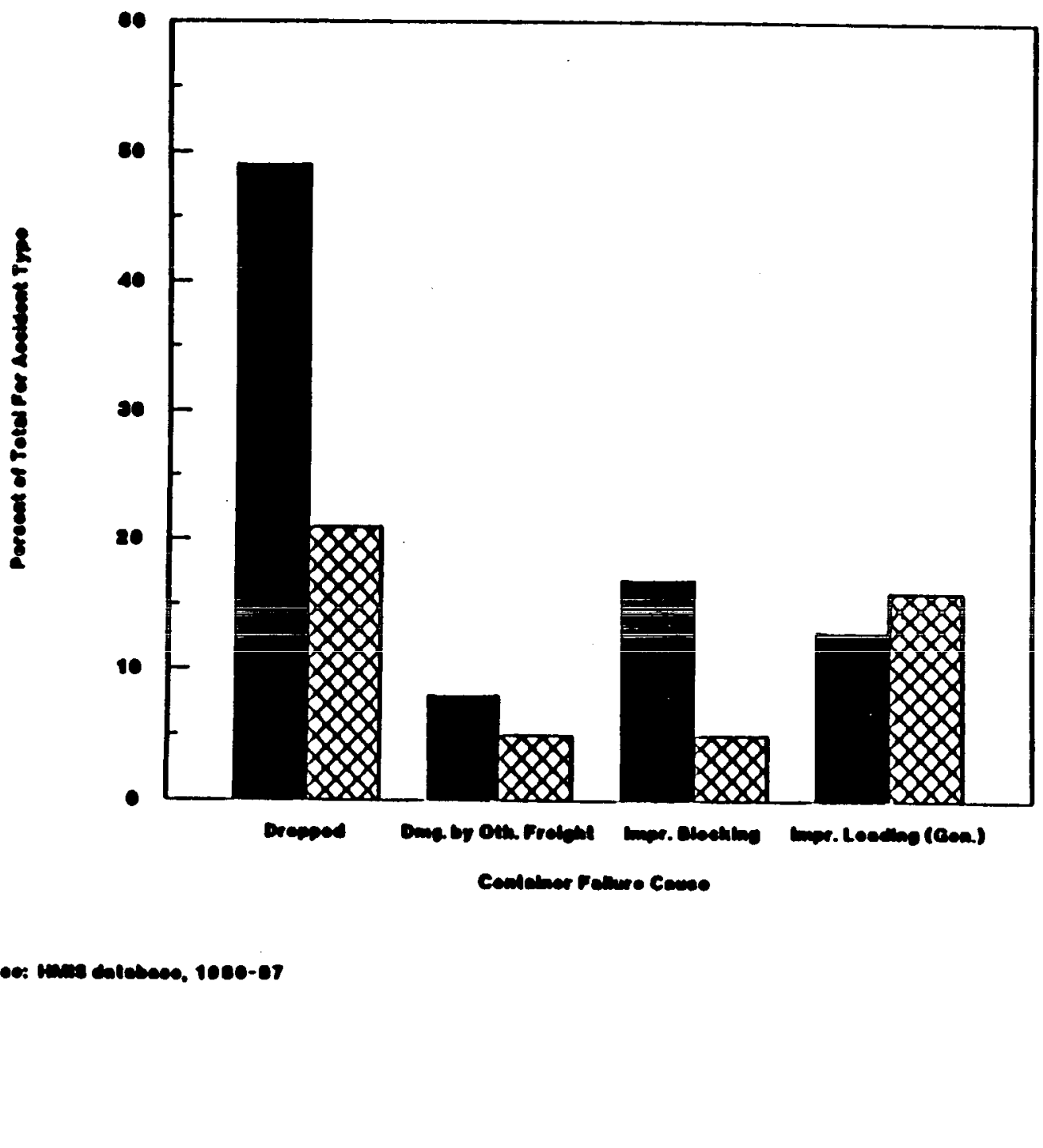

8880 


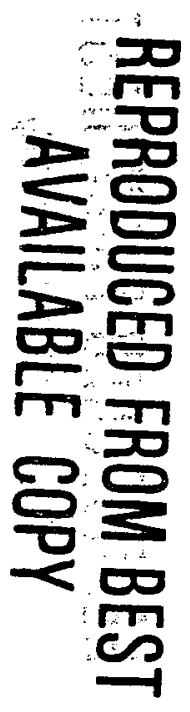

Flgure 11

Contalner Fallure Cause for Rall Tank Car $m$ -

Tranalt Accidents Involving Proxy Hazard Classes

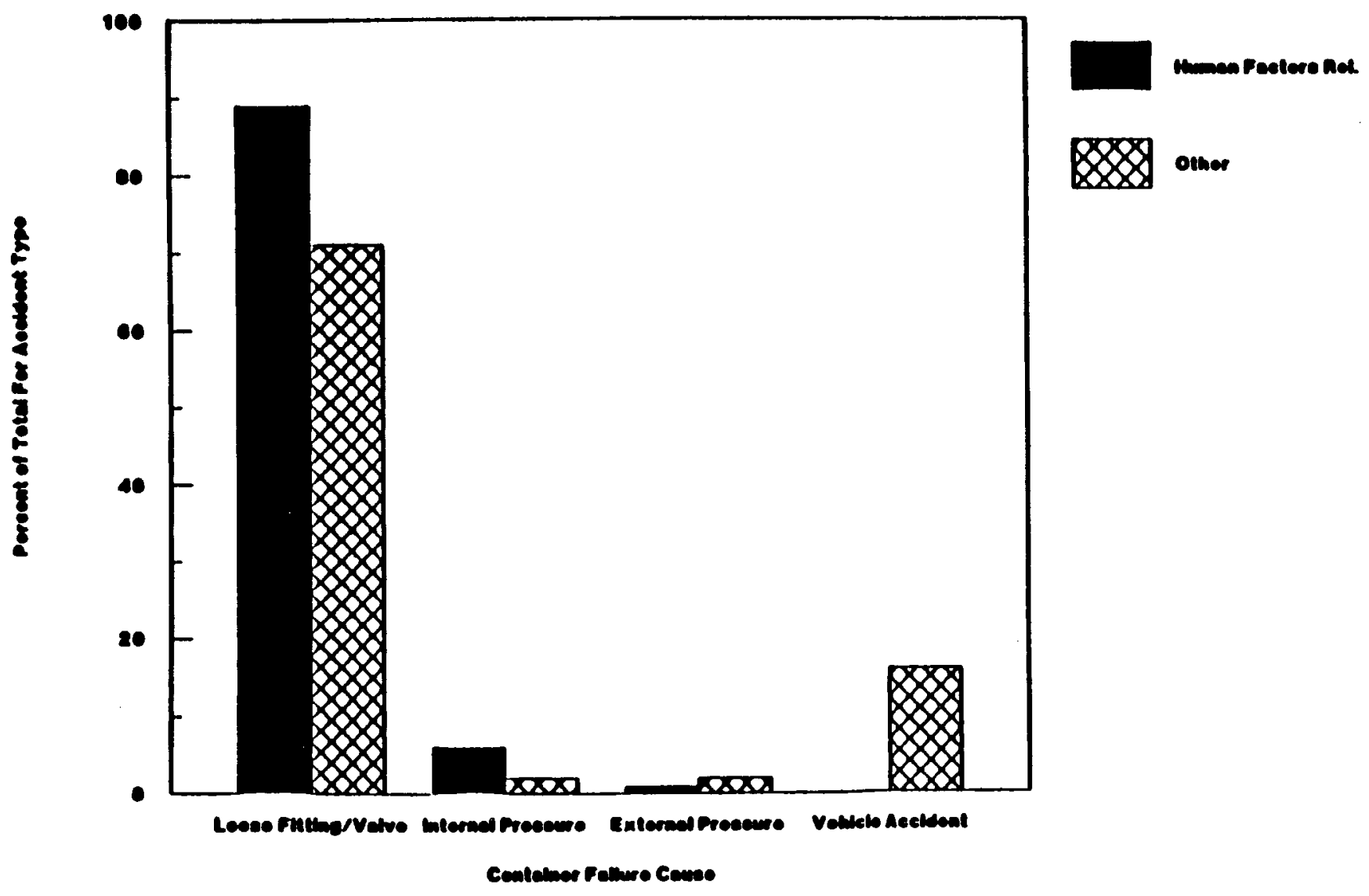


Flgure 12

Container Fallure Cause for Bulk Highway in-

Translt Accidents Involving Proxy Hazard Classes

N

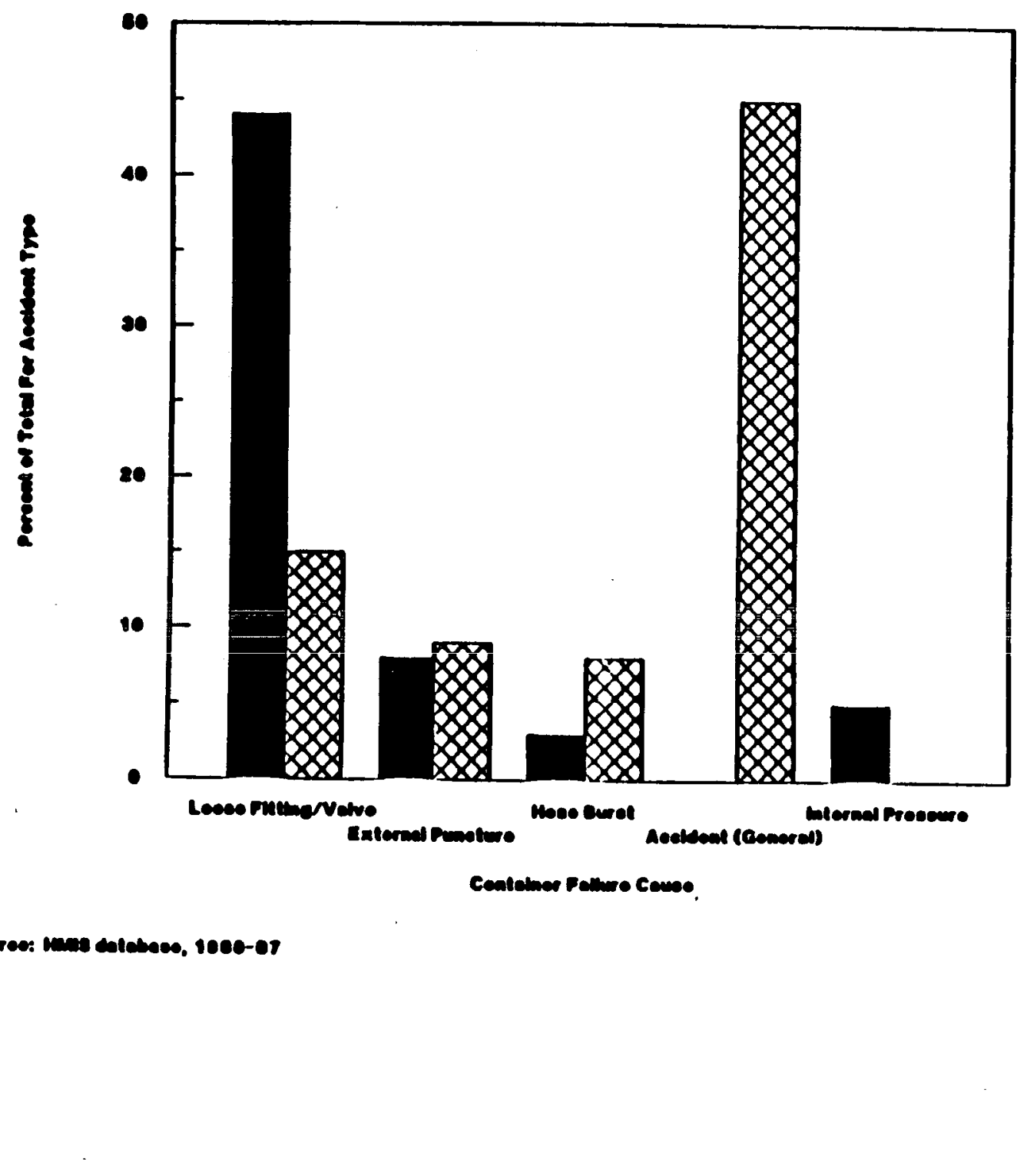




\section{Flgure 13 \\ Container Fallure Cause for Other In-Translt \\ Accidents Involving Proxy Hazard Classes}

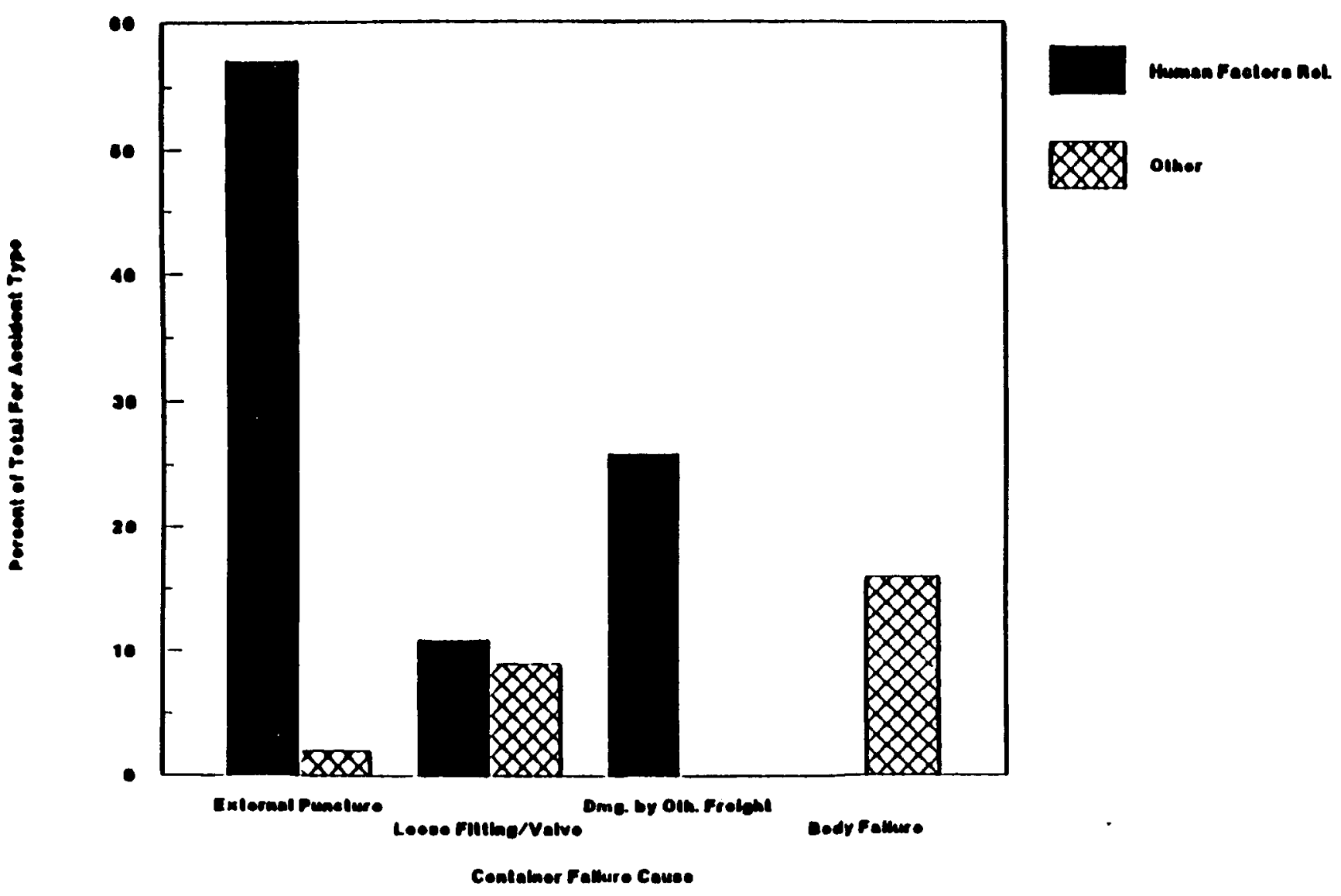

source: mase dotobsece, 1000-07 
Figure 14

Loading Accident Consequences by Container Class

for Proxy Hazard Classes

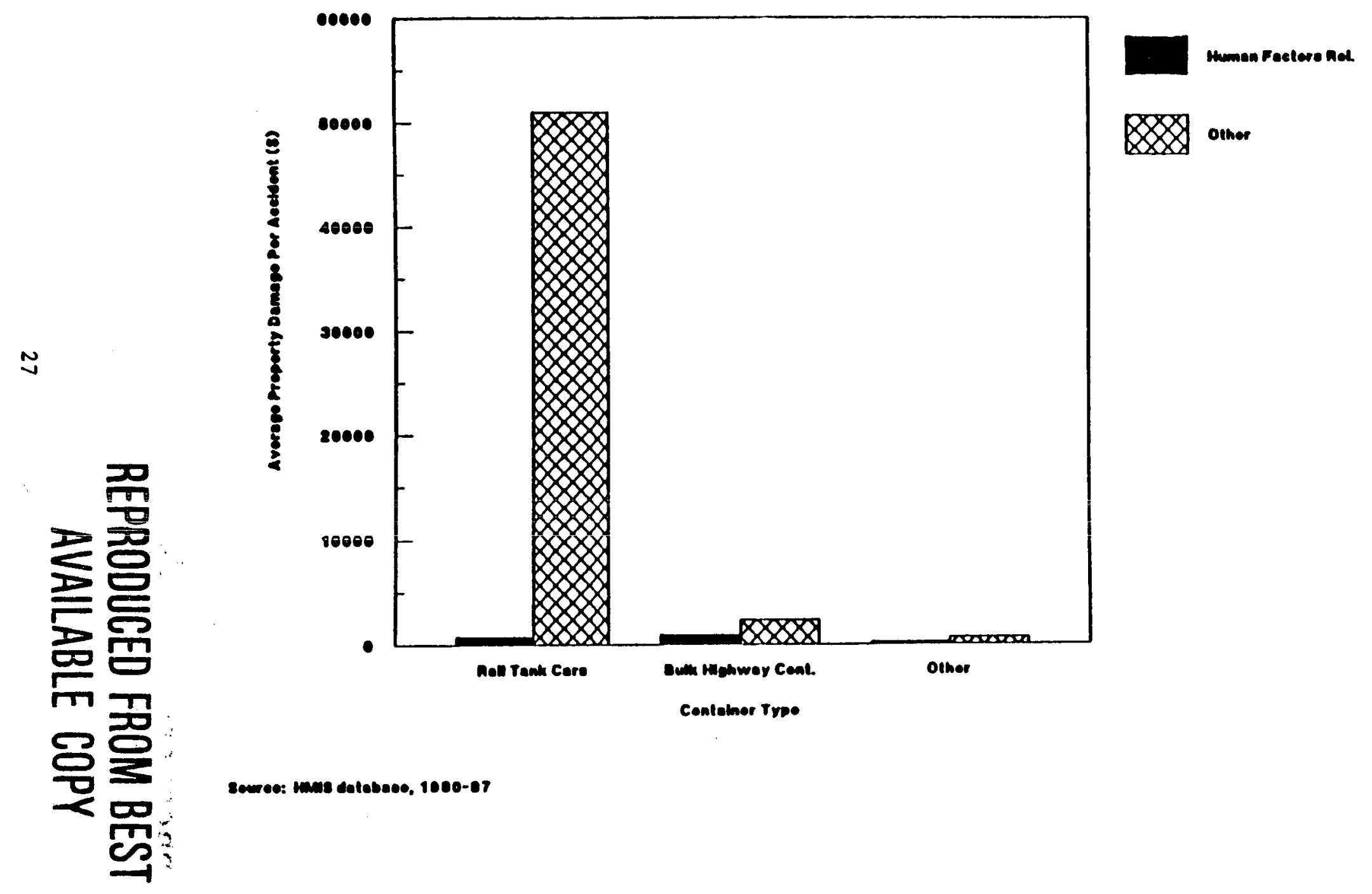


accident cause.* It appears that the accident severity for human-factors related loading accidents is considerably lower than for accidents caused by other factors, regardless of the container type under consideration. This same relationship holds for in-transit accidents, as noted in Figure 15.

* Simiar analyses were also conducted on fatalities and infuries. The results were highly correlated with those for property damage. ato 
Figure 15

In-Transit Accldent Consequences by Container Class

for Proxy Hazard Classes

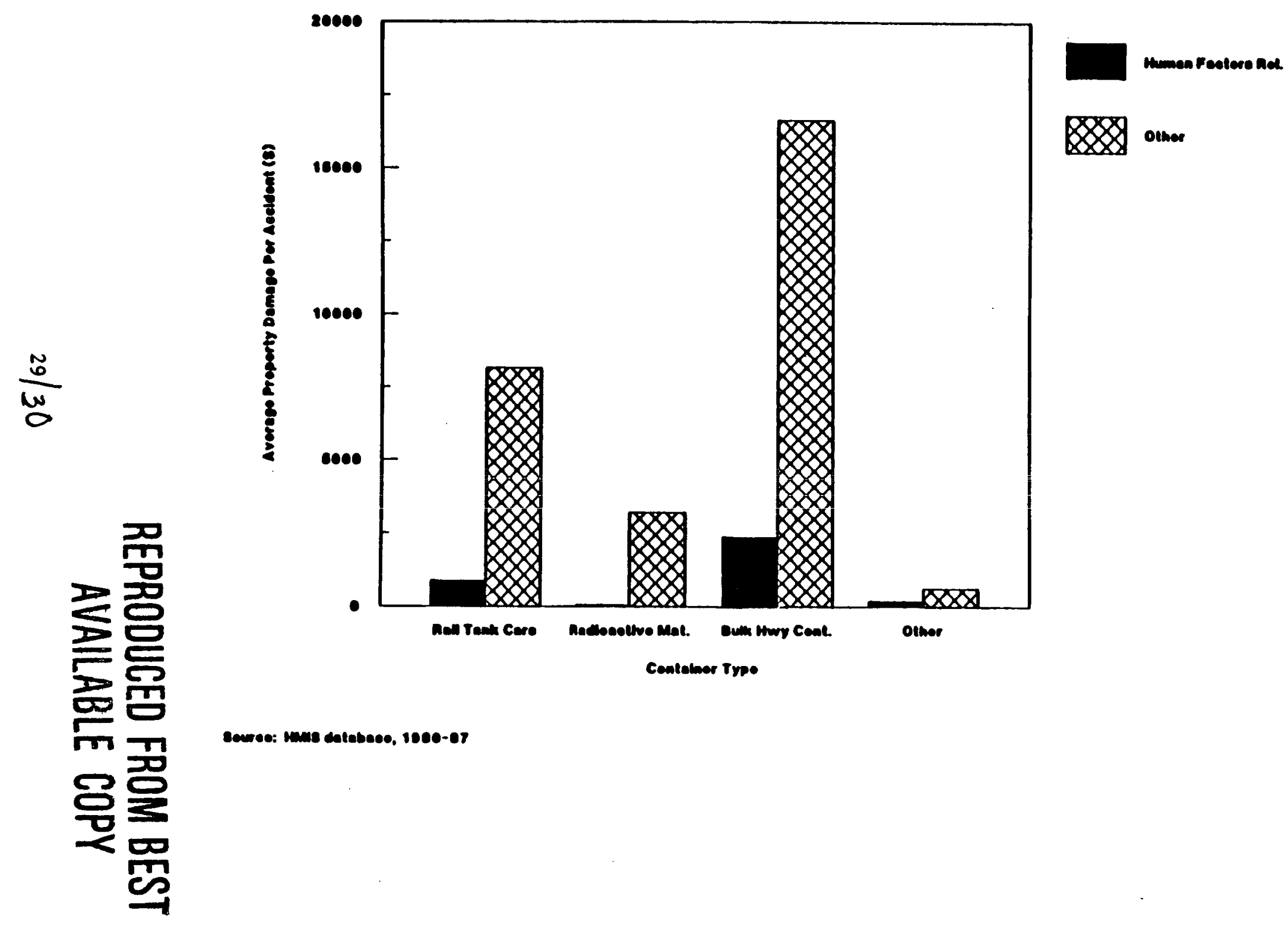




\subsection{SIGNIFICANT OR EMERGING HUMAN FACTORS PROBLEMS}

On the basis of the previous analyses, it is apparent that human error is a leading cause of accidents involving the transport of materials in containers that resemble radioactive waste shipments. It can be inferred from these results that human factors effects on radfoactive waste transport operations are likely to be significant to the point where a more formal DOE human factors research program and program policles should be established. While one can argue over the apparent lower accident severity assoclated with human factors-related accidents, both loading and in-transit; the high frequency of such events coupled with the public perception of a nuclear accident 1ndependent of severity, suggests that the occurrence of these accidents should be kept to an absolute minimum.

As noted earlier, most of the available accident databases are not capable of providing accident characteristics at a level that corresponds to the detalled identification of significant or emerging human factors problems. The exception, the NASS and FARS databases, can provide some insights for the trucking industry. The extent to which addftional information might be avallable from prior research studies to support this effort prompted the undertaking of an archival search for relevant literature.

\subsection{LITERATURE REVIEW}

The 11terature review process was conducted with the ald of a computerized search through the Transportation Research Information Service ('IRIS) f1le. From a list of several hundred potentialily relevant references, a review of abstracts resulted in the 1dentification of a small subset of these documents which were deemed relevant to the project scope. Most of this material was obtalned for use in this study.

A couple of observations are appropriate here regarding the human factors in transportation 11terature. First, there appears to be considerably more information and prior attention focused on human factors issues in the trucking 1ndustry relative to other modes, particularly in the past decade. Very little activity focusing on rall operations has occurred since the late $1970^{\prime} s$, and focus on marlne transport has been consistently sparse.

Concerning subject matter, most of the recent attention has focused on fatigue, tralning, and drug and alcohol abuse. Some of this is couched in extensive discussions of the environment in which drivers must operate, including present-day economic and managerial pressures. There has also been some attention focused on the cab environment, including the effects on occupational health (and attentiveness) from prolonied exposure to noise, vibration and other elements.

The avallability of NASS (and FARS) data, coupled with rather extensive outside literature on human factors in the trucking industry, led to a decision to fully develop an understanding of potential problems that might plague the truck transport of nuclear waste materlals. Th1s is addressed in Section 4.2. Although much more restrictive in nature, similar discussions for rail and marine transport are provided in sections 4.3 and 4.4, respectively. 


\subsection{HUMAN FACTORS IN TRUCK SAFETY}

This section discusses what is known about human factors in truck safety based on NASS (and FARS) database analysis, and a review of pertinent literature. It includes a discussion of significant and emerging driver behavior problems as well as the development of polfcy options to address these concerns. Vehlcle, roadway and economic factors are also described briefly, to the extent that they interact with the human factors area.

\subsubsection{Driver Behavior}

Driver behavior is generally recognized to be a function of both the characteristics of the driver and external factors affecting his attitude and performance. Driver characteristics can 1nclude experience, prior training, age (attitude), physical condition (fatigue, intoxication, other debilitations), and psychological state. External factors may include regulatory oversight (e.g.. Ilcensing, traffic enforcement) and the type of supervision exercised by the carrier.

\subsubsection{Driver Training}

Results from an analysis of 5 years of the NASS data (1981-85) indicate that several driver-related factors warrant further investigation. Figure 16 shows the level of prior driver training recelved by heavy-truck drivers involved in accidents, segmented by hazardous and non-hazardous cargo shipments. Indeed, the majorlty of accident-involved heavy-truck drivers never recelved any formal training, commercial vehicle or vtherwise, before operating a rig. Relatively speaking, drivers involved in accidents carrying hazardous cargo were more likely to have had formal training, although their absolute percentage of untrained drivers signals a serious deficiency.

In a survey of the general population of heavy-truck drivers, 23\% reported recelving driver training prior to becoming a professional driver (Regular Comon Carrier Conference, 1987). However, of those drivers who reported regularly handing hazardous materlals, $87 \%$ had not recefved any formal tralning on the speclfics of hauling dangerous cargo (Wyckoff, 1979). Surprisingly, though, drfvers with formal training, on the average, reported driving faster, misrepresenting thelr log books more frequently, exceeding the 10-hour shift limlt more regularly, and having more accldents per 100,000 miles when compared to drivers without formal training. Although these findings may appear counter-intultive, it is important to note that drivers with formal training are predominantly younger drivers whose safety performance may be impacted by age and experience as discussed in Section 4.2.1.5.

The lack of training is also assoclated with accident severity. According to analyses of NASS (1981-85) and FARS data (1983), 58 percent of heavy-truck drivers involved in accidents did not recelve prior training, as compared to 74 percent of truck drivers involved in fatal accidents. Both the preponderance of untrained drivers and the overinvolvement of untrafned drivers in fatal accidents warrant attention. 
Flgure 16

Driver Education of Accident-Involved

Heavy-Truck Drivers

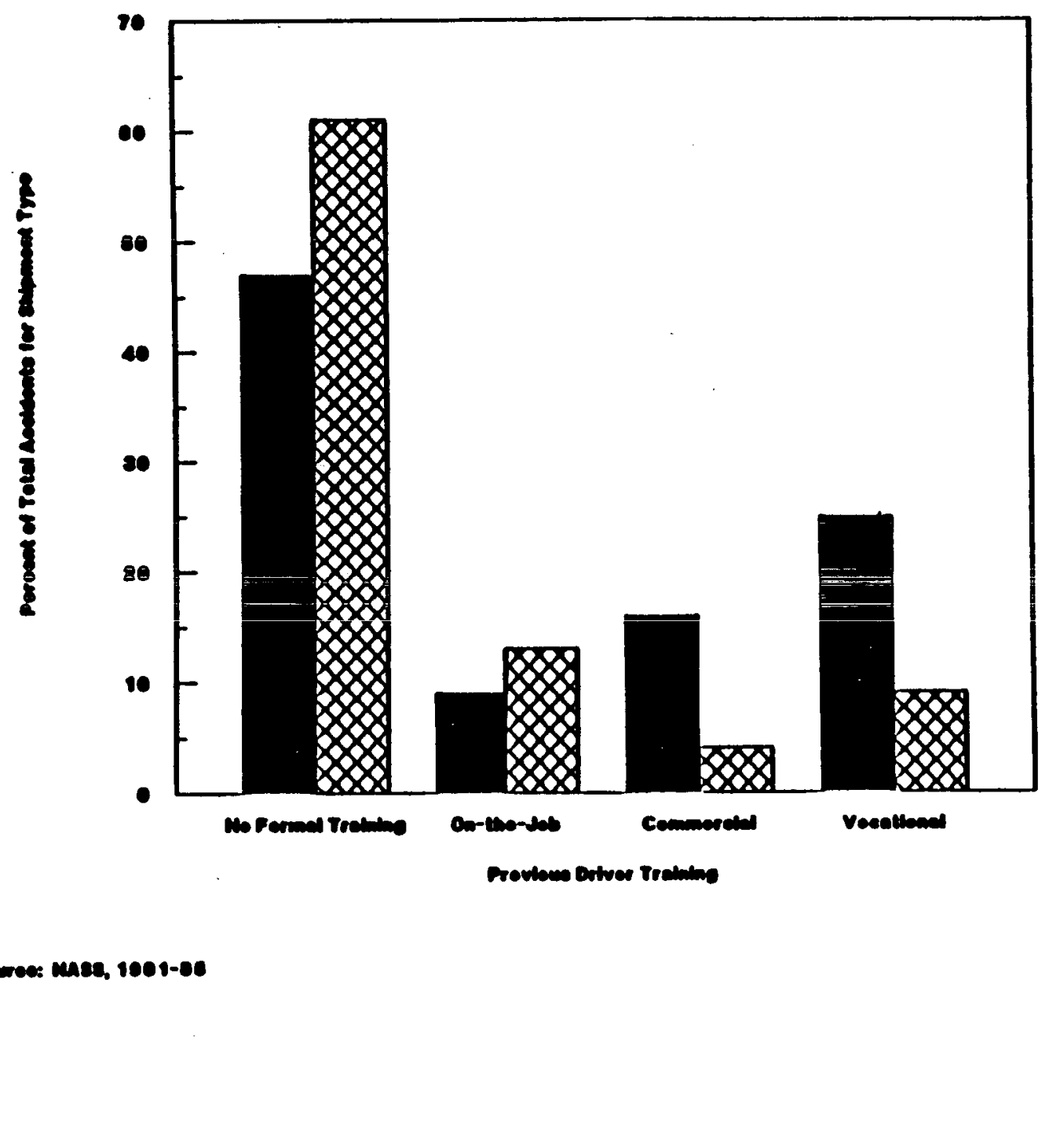

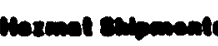

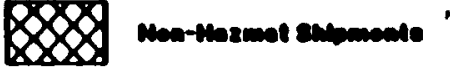

響

政

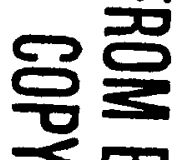

$\infty$

$\underline{\underline{S}}$ 


\subsubsection{On-the-Road Performance}

Where driver-related factors have been specified on the accldent report form for hazardous cargo accidents, * the most frequently clted occurrences Include driving too fast for conditions, poor lane changes, and disobeying traffic signals. A more detalled investigation of the role of human factors in truck accidents in Finland also polnts to fallures in controlling the vehicle, in estimating the traffic situation, and in perception as the principal causes when human error is cited as the primary factor. Driver attitude and the physical or mental state of the driver emerge as key accident characteristics when human error is given as a secondary cause (Stocker, 1987). Similar findings were reported in Oregon in an analysis of heavy-truck at-fault collisions - the principal causes were improper maneuvers, speed too fast for conditions, and driver fatigue and lnattention (Oregon Public Utility Commissioner, 1985).

The frequencies of driver error for the truck driver and for the driver of the other vehicle in truck accidents appear in Table 3, which shows the contrast between the operating performance of each party in crash circumstances in Washington State. Areas of poor performance by the truck driver Include inatcention, exceeding reasonable speed, following too closely, and 1mproper turning maneuvers.

Through the Federal Motor Carrier Safety Assistance Program (MCSAP), several States have also found excessive speed to be the most frequent human factor 1nvolving accident causation. For example, Maryland and Massachusetts as well as Oregon clte speeding as the most common accident causation factor.

The assoclation between speeding and accident causation deserves further consideration in the context of the recent increase in the speed 11mit to 65 mph on many rural 1nterstates. A 1987 survey of truck drivers' opinions carried out in Florida for the Regular Common Carrier Conference addressed driving habits of long-haul truck drivers under the new posted speed limits. Table 4 shows the results reported from interviews with 1,762 truck drivers. Furthermore, seventeen percent of the drivers intervlewed indicated that they are being asked to make faster dellveries now than before the 65 mph speed Ifmit was approved. This apparent push toward higher truck speeds and faster expected delivery times, even on roadways whose posted limits did not change, is disturbing.

Higher posted speed limfts also increase the varlation in speed of any vehicle from the average speed of all trafilc. Greater variation in speed leads to lncreased accident likelihood by providing more conflict situations, such as passing maneuvers and braking (Solomon, 1964).

* In the National Accident Sampling System (1981-85), driver-related factors in hazardous cargo accidents are specifled approximately $30 \%$ of the time. 
Table 3. Contributing C1rcumstances to State of Washington Crashes in 1984

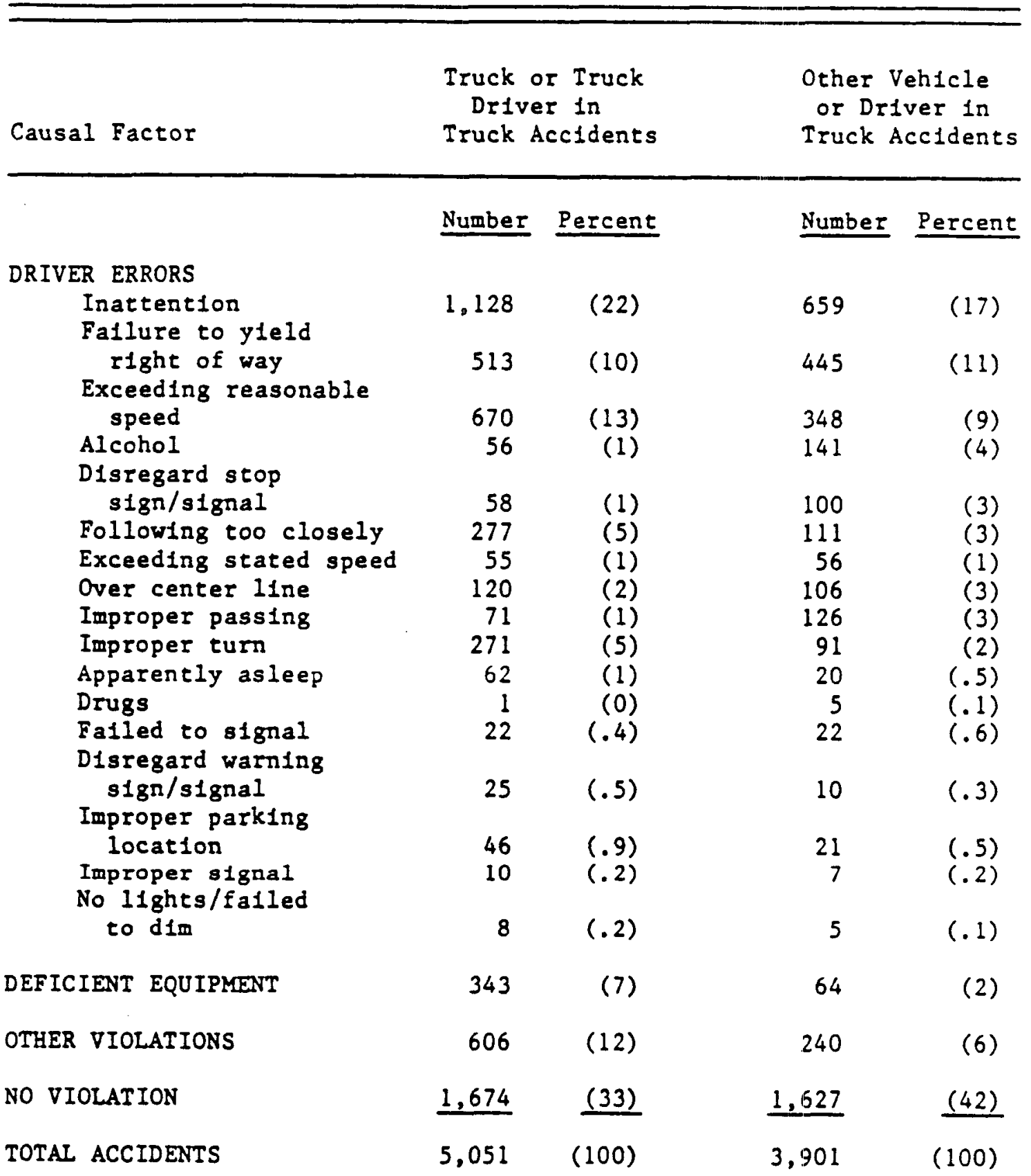

Note: In some accldents there were no contributing clrcumstances noted, while in others there were several noted.

Source: NHTSA, based on data from the Washington Ut1litiles and Transportation Comission. 
Table 4. Interviews About Truck Crusing Speeds of Long-Haul Drivers

Since Approval of the $65 \mathrm{mph}$ Speed Iimlt, Have Truck Cruising Speeds Increased, Decreased, or Stayed the Same on Roadways Where:

$$
\text { Increased Same Decreased }
$$

$55 \mathrm{mph}$ is still posted

$26 \%$

$69 \%$

67

$65 \mathrm{mph}$ is now posted

$30 \%$

$68 \%$

$2 \%$

Source: Regular Common Carrier Conference, 1987. 


\subsubsection{Previous Driving History}

Evidence exists that heavy-truck drivers 1nvolved in accidents have a history of previous safety violations, even those carrying hazardous cargo shipments. As noted in Figure 17, in many instances a truck driver involved in a NASS-recorded accldent had received previous citations, particularly for speeding and other moving violations, and had been involved in previous accidents. The national estimates from NASS data (1981-85) show that 30 percent or more of truck drivers involved in hazardous cargo accidents had at least one prior speeding conviction in the previous 3 years and at least one additional moving violation. One in every four accident-involved drivers carrying hazardous cargo had at least one accident prfor to the recorded one. As in the case of driver training, although accident-involved drivers of hazardous cargo fared slightly better than the accident-involved truck driver population as a whole, it is apparent that poor driving records are scattered among a considerable number of truck drivers.

\subsubsection{Drugs and Alcohol}

Alcohol 1mpalment studies based on pollce reports often show a low percentage of intoxicated truck drivers. However, studies using blood tests and small samples have shown that as many as $33 \%$ of fatally injured truck drivers had positive BAC's (Ranney, et al., 1984). The preliminary results of a recent special heavy-truck accident investigation being conducted by the National Transportation Safety Board (NTSB) Indicate that over 17 percent of completed cases involved a driver impalred by efther alcohol, drugs, or both. In the majortty of accidents, the driver was elther not tested or refused testing, which may explain the discrepancies between these results and those derived from police reports. Moreover, all of the 1mpalred-driver cases in the NHTSA study 1nvolved some type of 1mproper driver judgement that resulted in the accident.

Additional evidence of a growing drug and alcohol problem comes from a 1986 survey sponsored by the Regular Common Carrier Conference of 1,319 long-haul, tractor-trafler truck drivers operating out of Florida (Beflock, 1987). In this survey, drivers were asked their perception of fellow drivers' usage of drugs and alcohol. The "average" respondent felt that 36 percent of fellow drivers sometimes drive under the influence of drugs. Percelved use of alcohol was lower; 18 percent of all drivers were described as sometimes driving under the influence of alcohol.

Further Indication that a drug problem may exist among truck drivers is presented in an Australian study of heavy-truck safety (Lees, 1987). A survey by the National Road Frelght Industry Inquiry found that 66 percent of long-distance drivers use drugs to stay alert.

Alcohol 1nvolvement and accident consequence are strongly correlated. Figure 18 shows the severity of infuries as a function of whether heavy-truck driver drinking was involved. Regarding accldent types, single-vehicle, road departure accidents, often at night, were found to be predominant among drinking truck drivers (Ranney, et al., 1984). The correlation between truck driver drinking and accident severity suggests that a drinking driver may elther fall to react or react more slowly and less definltively in a situation with accident potential, helghtentis the intensity of a subsequent crash. 


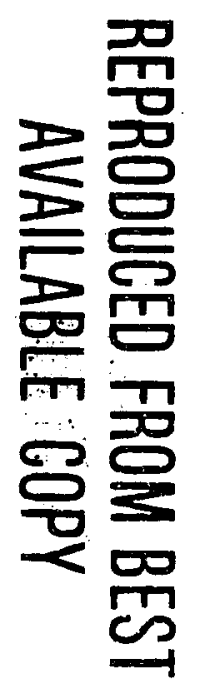

Figure 17

Prevlous Driving Records for Accldent-Involved

Heavy-Truck Drlvers

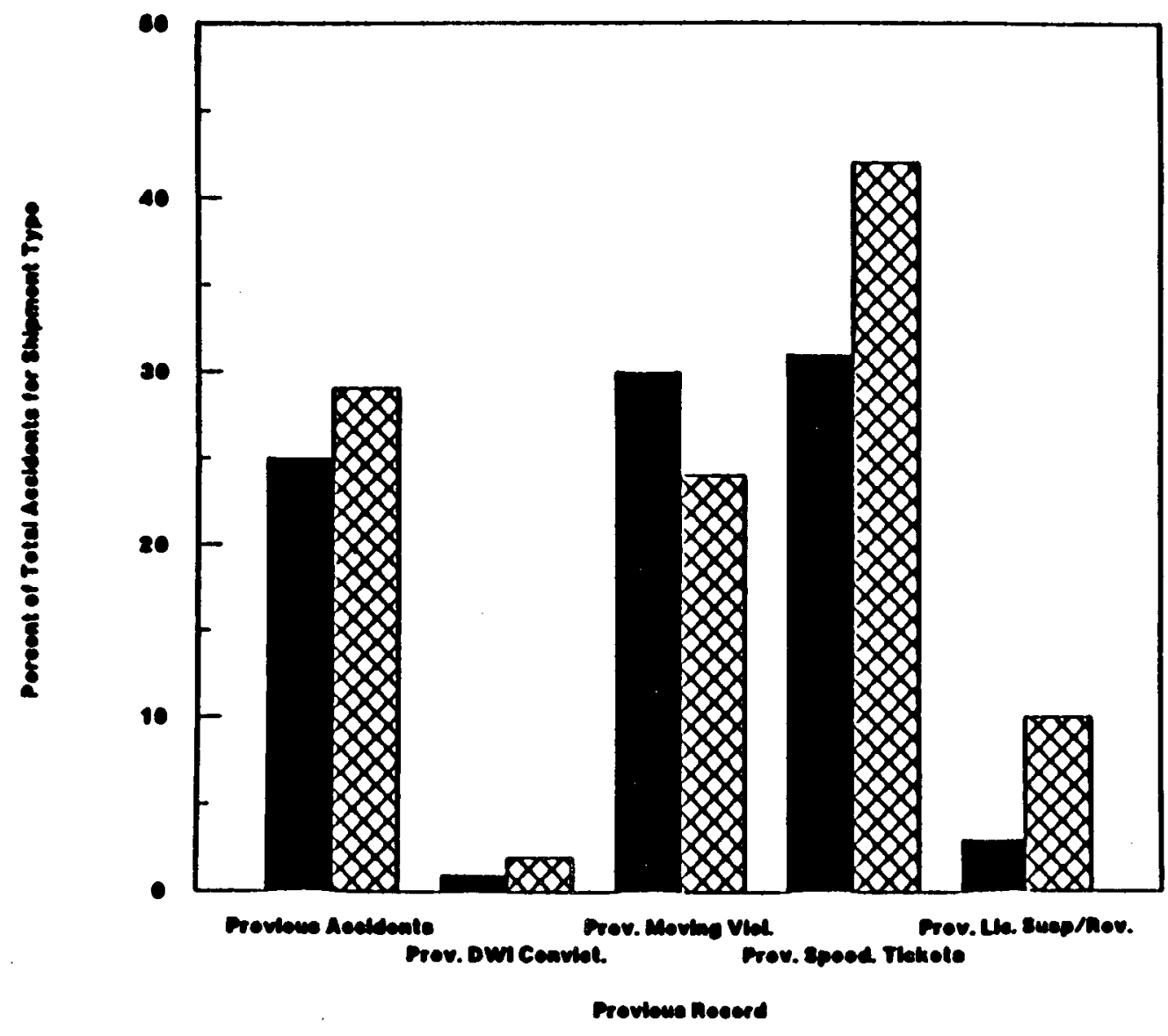

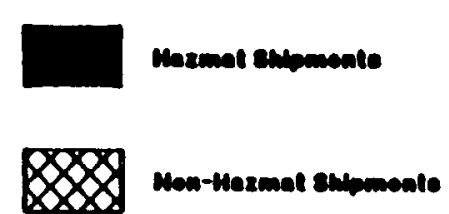




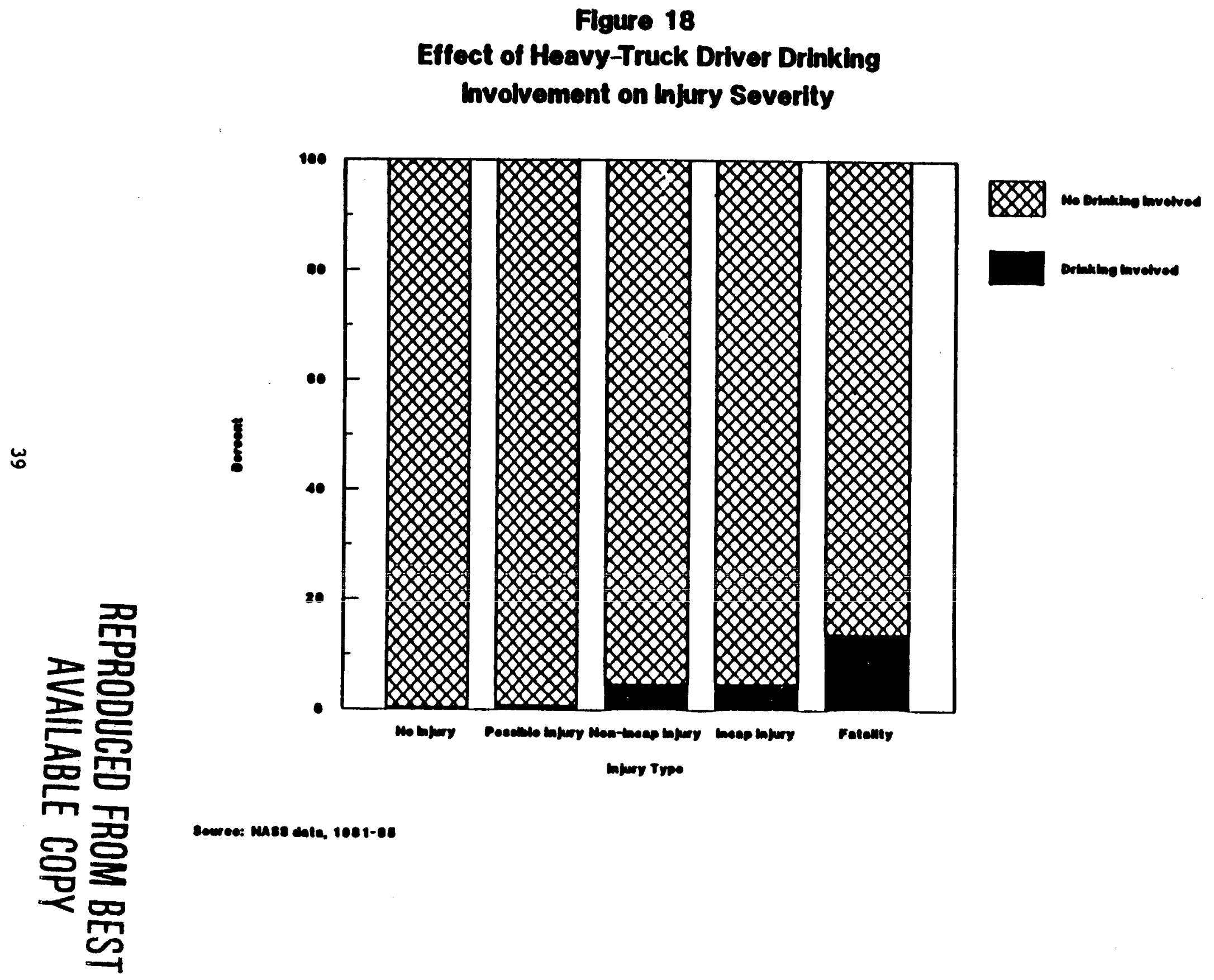




\subsubsection{Age and Experlence}

Young and 1nexperfenced drivers are the truck drfver groups with the highest risk of accident (Jones and Stein, 1988; Sanders, 1980; Green, et al., 1980). It has been reported that drivers under 25 years of age are s1x times more likely than other heavy-truck drivers to be involved in an accident (Hackman, et al., 1978). Other studies indicate that drivers with less than 1 year of experfence constitute 1 percent of the carrier workforce, yet account for 3 percent of the accidents (Jovanis, 1987).

According to one study, by their own estimates, younger truck drivers complained more often about monotony, boredom and loneliness. They also were reported to be more than twice as Iikely to regularly experfence fatigue at the wheel in comparison to the heavy-truck driver population as a whole, and more likely to drive after drinking or using marfjuana. A greater adherence to safety rules was, as expected, also correlated with increased age of the driver.

Figure 19 shows the age of accldent-involved drivers, segmented by hazardous and non-hazardous cargo, based on an analysis of NASS data. There appears to be no indication that older drivers are associated with more dangerous cargo movements. Therefore, the increased "rlsk" of younger drivers does not appear to be reflected in driver assignments involving hazardous shipments.

\subsubsection{Fat1gue}

As shown in F1gure 20, a European truck safety study found that drivers traveling several days in a row, as a group, spend more time working than other drivers over a 24-hour perfod (Hamelin, 1987). Although it cannot be proven conclusively from observing this figure, it is concelvable that these drivers work as frequently as other drfvers during the day, yet remain on duty, predominantly driving, after normal business hours. Such drivers either spend daytime hours involved in driving or loading/unloading, preceded or followed by additional driving. This pattern can lead to both sudden fatigue, due to temporary 1rregularities of the sleep cycle, and accumulated fatigue, due to long working hours. The fatigue, in turn, reduces the drivers' sensorlal and motor capacitles.

Using a survey of truck driving patterns to measure exposure, accident experfence and exposure were also compared to ascertain perlods of high accldent risk (Hamelin, 1987). Figure 21 shows that accldent 1nvolvement rates generally increase throughout the day, reaching a daylight peak at lunch time, and then growling more dramatically at the end of the afternoon, Into the evening, and late at night. Flgure 22 shows that accident involvement rates are relatively high for short work spans, then diminish, and increase again for shifts lasting more than 12 hours. A risk peak in the first hour of any shift has been reported by other heavy-truck safety research conducted on clrcadian rhythms (Jovanis, 1987), as well as a higher incidents of reported dozing among drivers who admit regularly to exceeding a 10-hour driving shift (Wyckoff, 1979$) \cdot$,

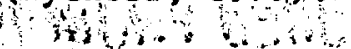


Flgure 19

Driver Age for Accident-Involved

Heavy-Truck Drivers

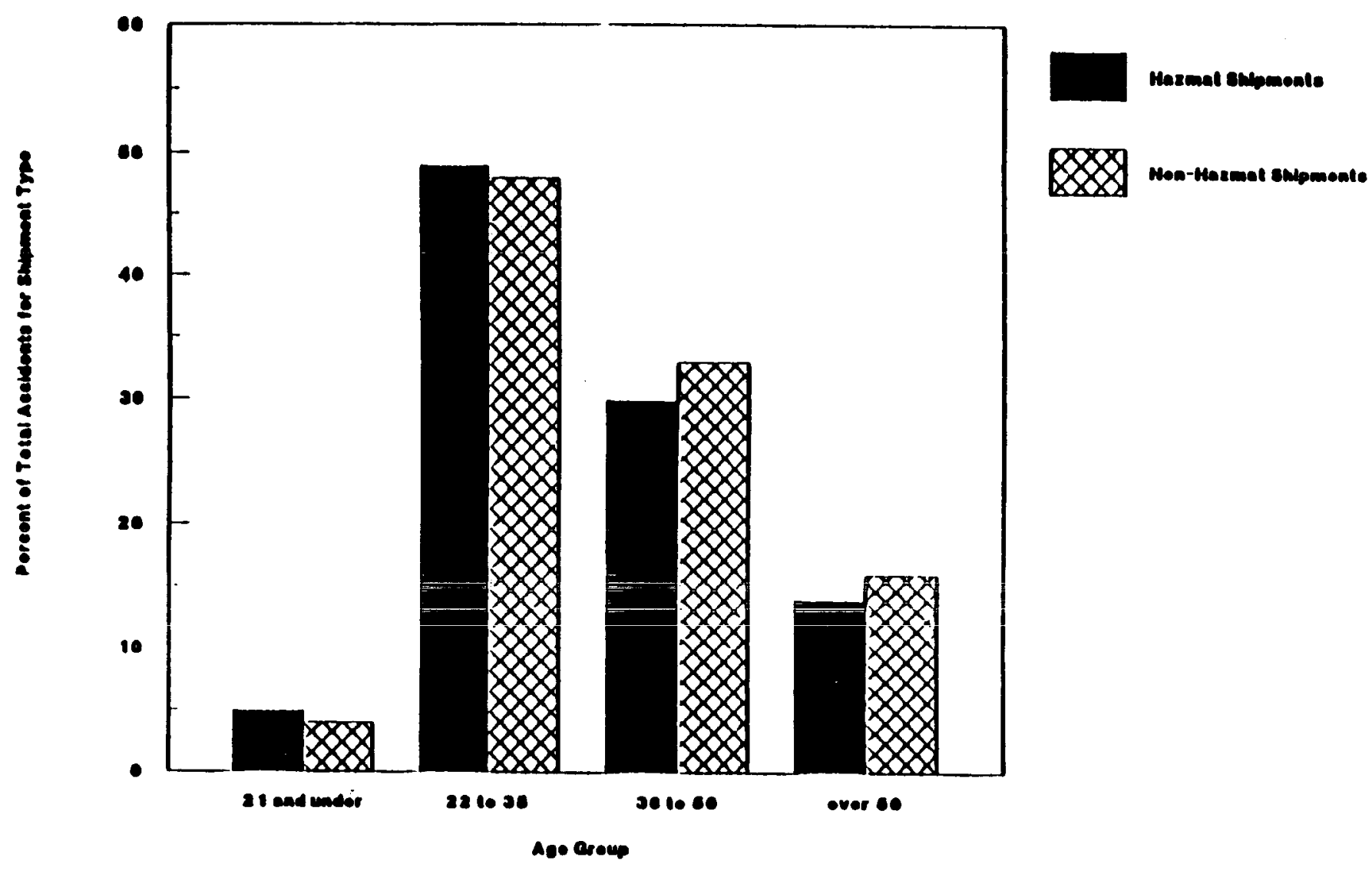

Courco: Mase, 1001-e0 
REPRODUCED FROM BEST

\section{AVIII_ABLE COPY}

Figure 20

Truck Driver Activity Levels by Time of Day

Drlvors Coming Back Home Every Day

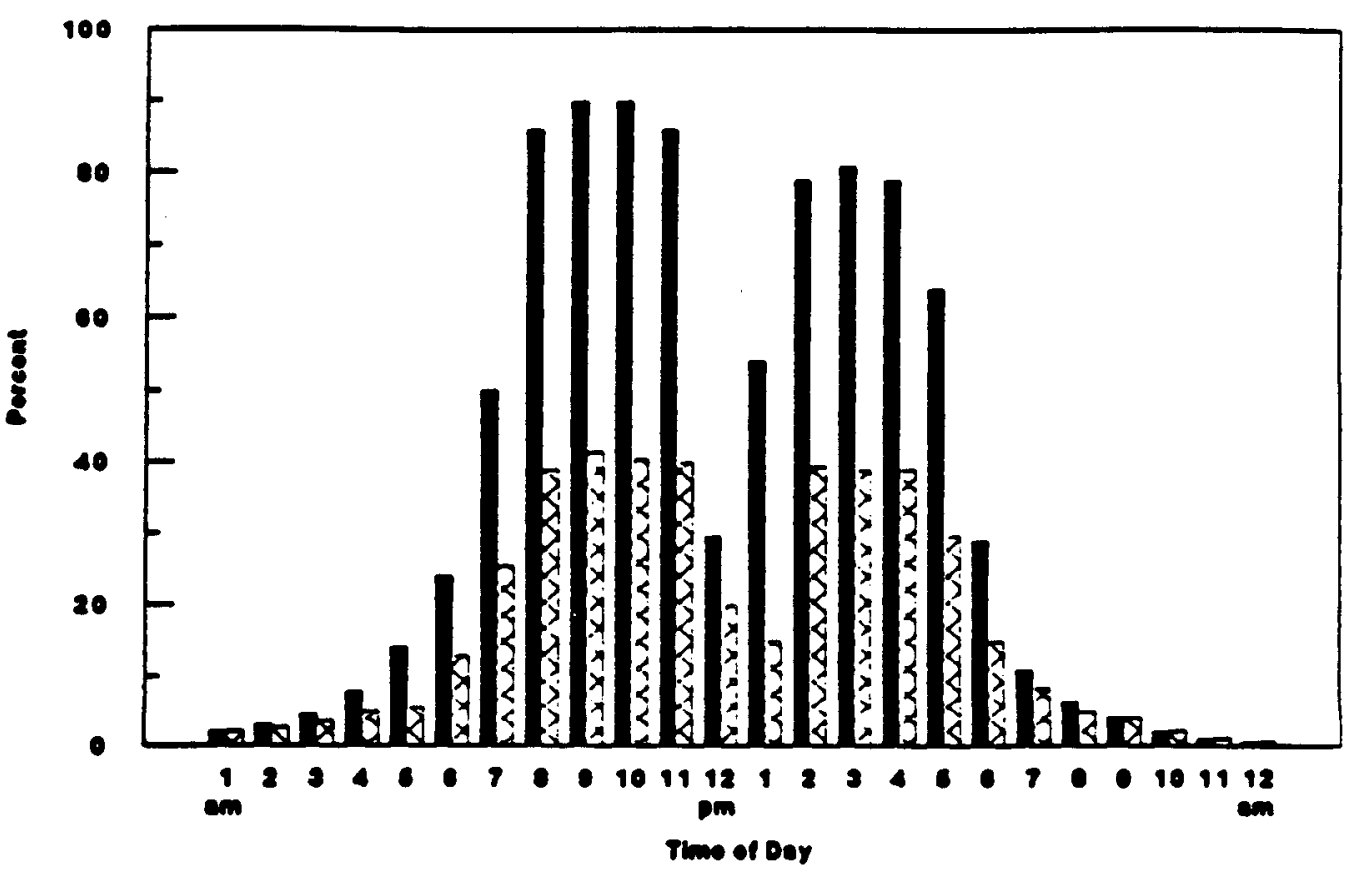

Drivers Away From Home - 2 Days or More

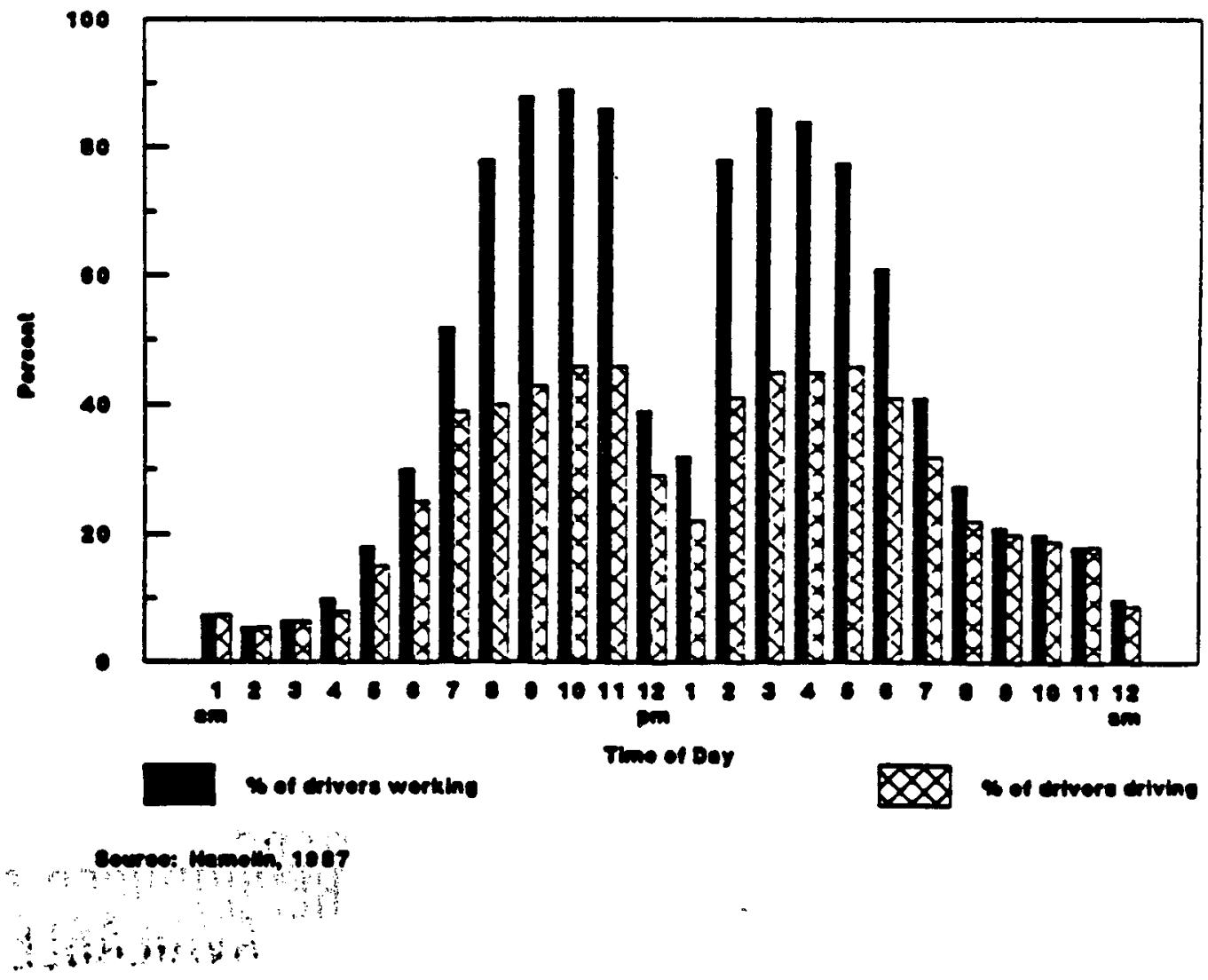


Figure 21

Truck Drlver Risk by Time of Day

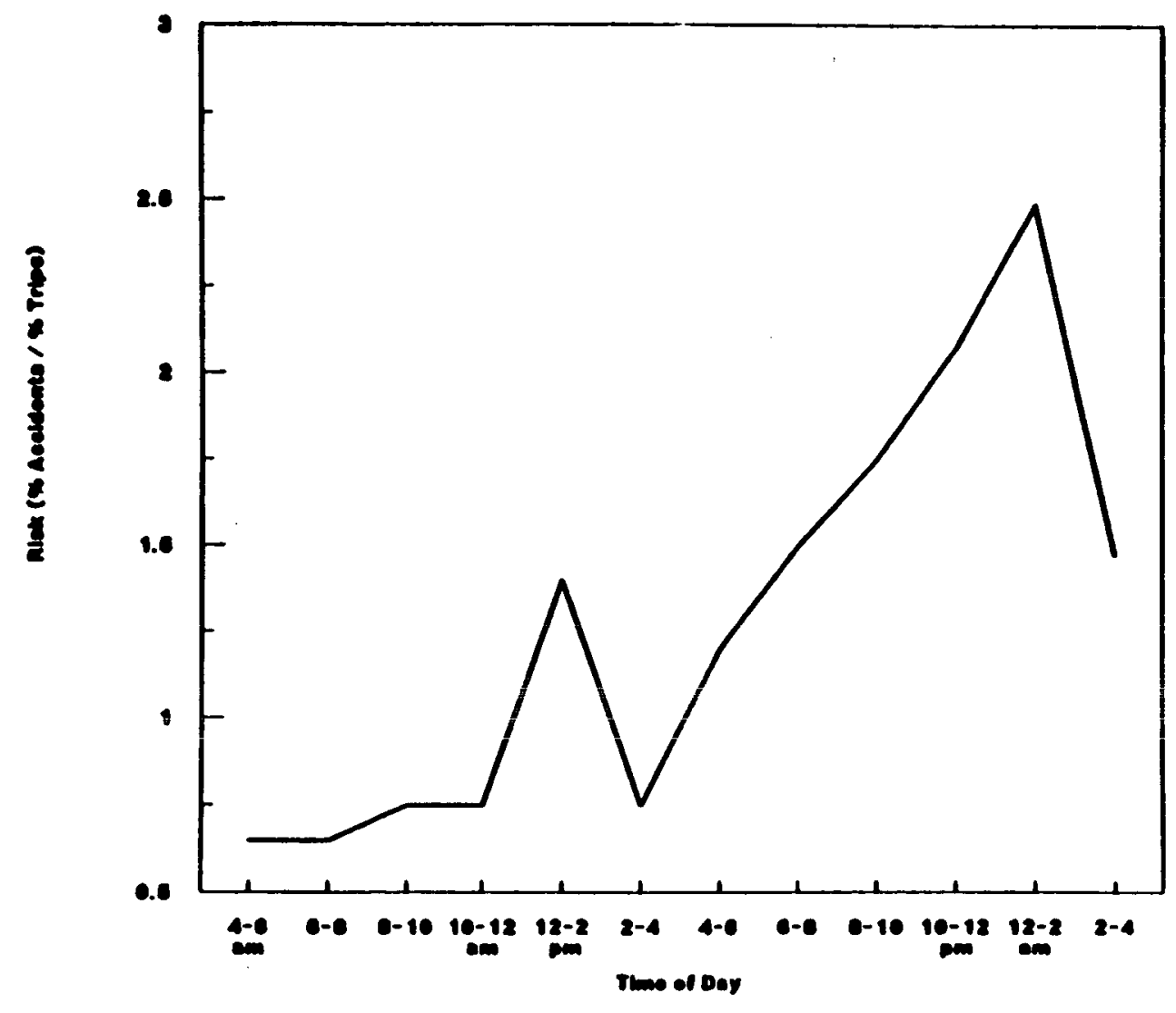

Courco: Memociln 1907 
Figure 22

Truck Driver Risk and Duration of Activities

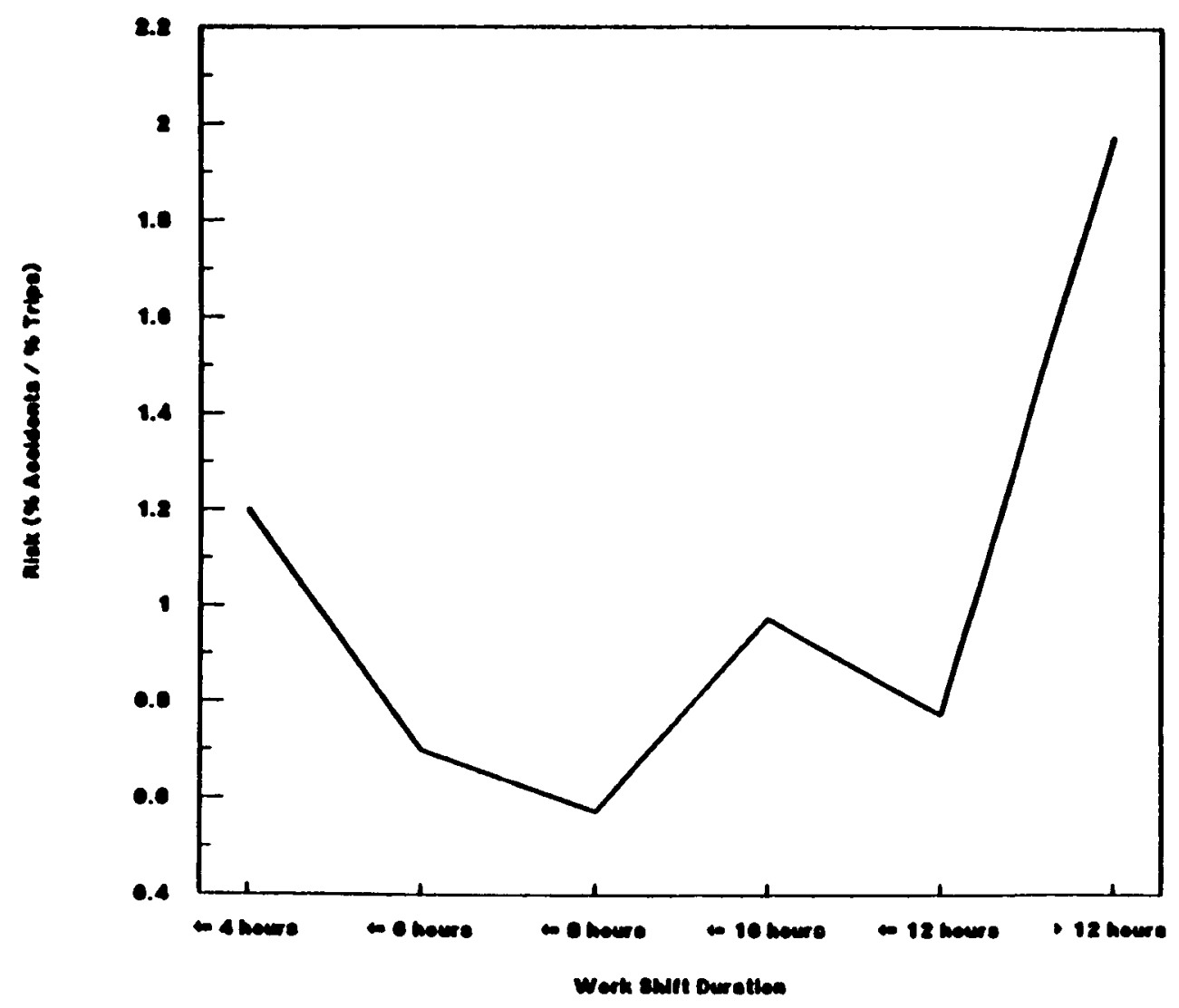


Significant increases in driver errors and decreases in alertness have been noted as early as the fourth hour of driving time in a shift, and generally increase throughout the trip, except for a slight recovery near the end of the trip (Harris and Mack1e, 1972). The lowest levels of alertness occur for most drivers between 2:00 a.m. and 7:00 a.m. Moreover, the adverse effects of prolonged driving are probably more pronounced for drivers aged 45 or older than for younger drivers. Thus, the greater experfence of older drivers, a safety enhancement during the early hours of a shift, is offset somewhat by physical 11mitations of older drivers, if the shift duration exceeds a threshold. Finally, drivers on irregular schedules experienced more fatigue than drivers on regular schedules, and the effects tended to occur earlier (Mackle and M1ller, 1978). Drivers using a sleeper cab for rest perlods experfenced greater fatigue than did relay drivers, although drivers who "rest" in the seat of their cabs were more prone to dozing on the road than those using the cab sleeper (Wyckoff, 1979).

As noted in Figure 23, accident data involving interstate comercial motor vehicle drivers show fatigue-classifled accidents as proportionally higher during the hours between 11:00 p.m. and 8:00 a.m., emphasizing the 1mportance of clrcadian rhythm (Hackman et al., 1978). The NTSB, too, notes fatigue (or hours of service) as a factor in over 30 percent of 1 ts accident investigations (NTSB, 1987). Instances of 26-31 consecutive hours of driver duty time prior to the accident were documented, some as a direct result of carrier dispatch, delivery, or other requirements.

A relationship between heavy-truck accident severity and accident occurrence by time of day 13 also apparent. Flgure 24 shows that a disproportionately larger number of fatcl accidents occur between midnisit and 6:00 a.m. Although fatigue may be a contributing factor, this may also be due to problems assoclated with dark conditions. However, a higher accident severity assoclated with accidents attributed to dozing was also reported by Wyckoff (1979).

\subsubsection{Vehicle Factors}

Vehicle design and performance affect truck safety, as do maintenance and operating practices. Design and performance 1ssues 1nvolve brake system capabilities, handling and stability, vehicle crashworthiness, and truck occupant protection. Malntenance practices include preventive maintenance as well as replacement of inoperable or worn parts. Vehlcle operating practices Include cargo loading, both in terms of tledown, overall weight, and weight distribution.

The 1mpact of vehicle factors in an accident may be more subtle than driver factors. Vehicle factors may not precipitate a crash but can reduce the vehicle's performance capabilities below the threshold where safety can be malntalned when an unusual driver action is taken. These factors are also more likely to have a significant role in highway operating environments, such as heavy traffic, curves, or narrow roadways, where, peak vehicle performance may be needed.

The subtleties of the role of the vehicle in aciderts are emphasized in an examination of Oregon accident records for heavy trucks." Vehicle defects were not typlcally the designated cause of an accident (Oregon Public Utility 


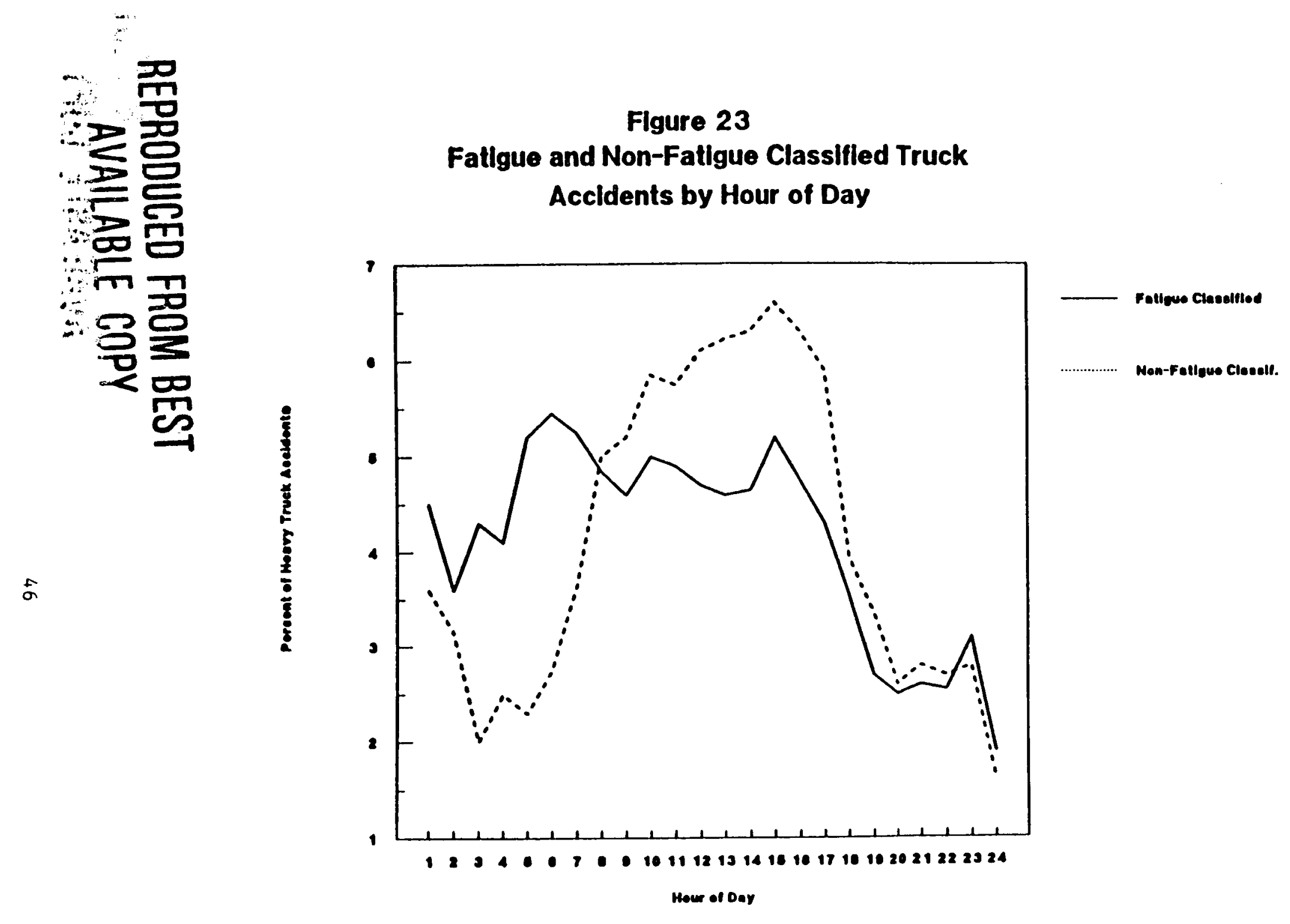

Aowree: Hackmen, of ab, 1070 
Figure 24

All Accident and Fatal Accident Involvements

by Time of Day for Comblnation Trucks

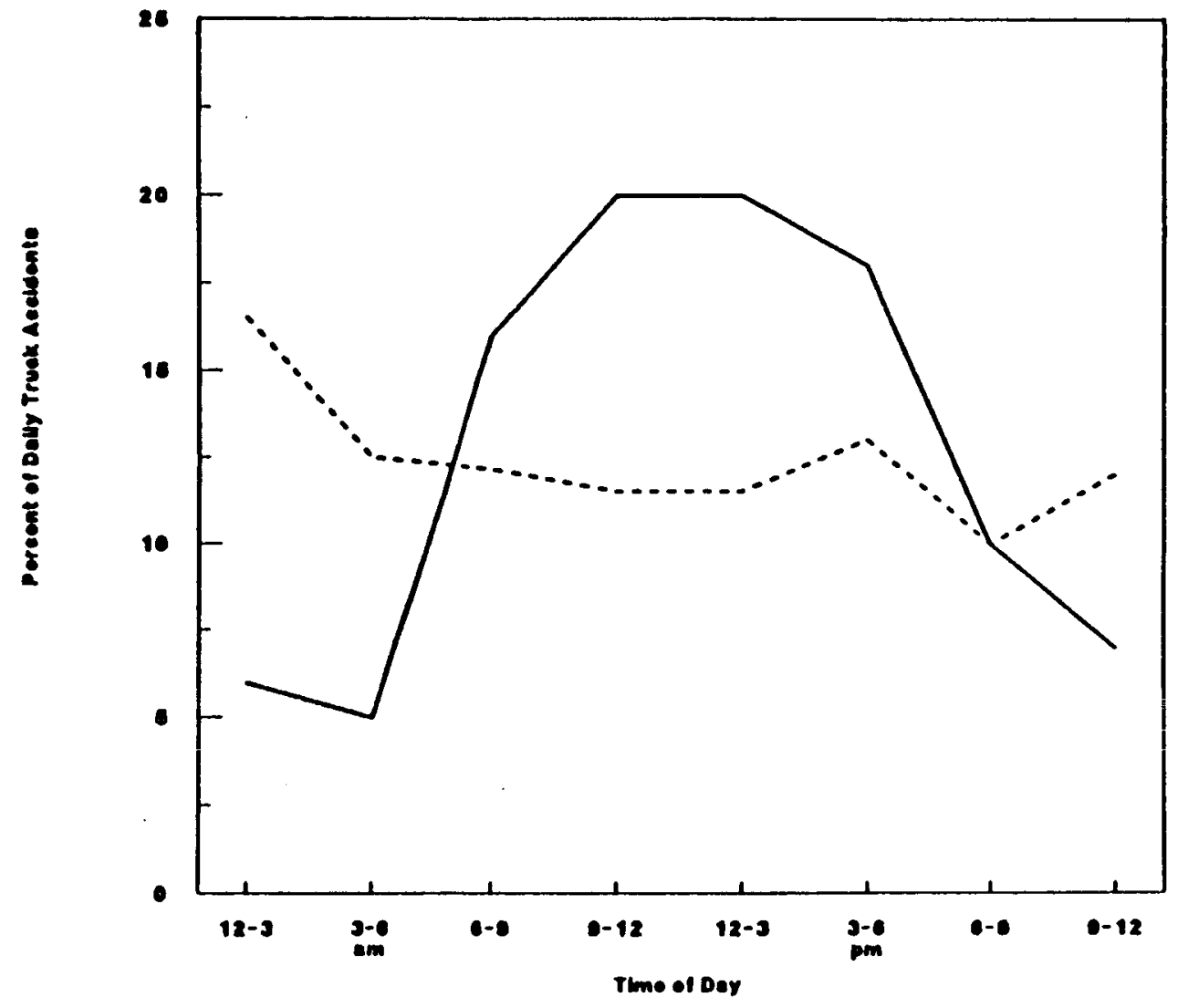

Fatal volweular Aceldonlo

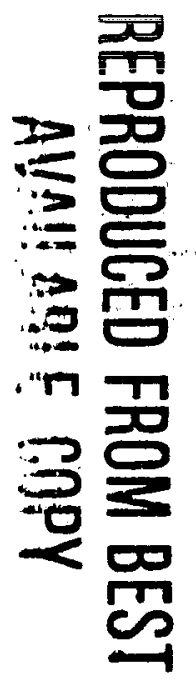

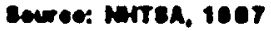


Commissioner, 1985). However, when truck-at-fault accidents were disaggregated, over 20 percent of the accidents were linked to mechanical defects. Glven the known blases toward driver error as the reported cause of an accident, this analysis identifies vehicle factors as important for accident prevention as well as for mitigating accldent severity.

\subsubsection{Braking System}

Problems associated with vehicle mafntenance are evident in the results of State-conducted vehicle Inspections as part of the Federal Motor Carrler Safety Assistance Program (MCSAP). Although the results vary among $S$ tates for reasons which may be related to the process of selecting vehicles for inspection, the condition of much extsting equipment is so deficient that a significant number of trucks are placed out of service fmediately. Based on ali cited equipment violations, brakes are listed as the most common problem, followed by poor lighting and tire condition. Accident causation studies also corroborate this relationship. Of all heavy-truck accidents associated with mechanical defects, brake system fallures were the single largest group cited, const1tuting 31 percent of the total (BMCS, 1979).

The nature of brake problems has been documented in greater detall by the Oregon Public Utility Commission, which found that over 60 percent of brake violations related to brakes being out-of-adjustment; another 14 percent related to problems with the brake lining. Therefore, roughly three of every four brake-related citations identifled problems that normal brake maintenance could easily detect and correct. NTSB's Investigations revealed that in many cases the truck driver had responsibility for proper brake adjustment, but the carrfer had not required or furnished approprlate training (NISB, 1987).

Existing truck braking systems must be kept adjusted and well maintalned to accommodate sudden braking or other avoldance maneuvers without causing the truck to jackknife, which is consldered a significant problem today. Jackknifing potential is exacerbated by wet road conditions, and is especially prevalent among 11ghtly loaded or empty vehtcles (Jones and Stein, 1988; Winkler, et al., 1983).

\subsubsection{Vehicle Handing and Stability}

Handling and stability problems often lead to vehfcle rollovers, which, In turn, are strongly correlated with accident severity. Rollovers are more likely to be associated with accidents involving a fatality relative to all heavy-truck sccidents (NHTSA, 1987). Other studfes show that the risk of infury is higher in rollover accidents involving a single vehicle relative to multiple-vehicle accidents (Jones and Ste1n, 1988).

Rollovers are more likely to occur on curved roads, where vehicle contributory factors include load shifting, deficient brakes, and deficlent tires (NHTSA, 1987). Drtver-related factors 1nclude inattention, falling asleep, loss-of-control/skidding, speeding, and avoldance maneuvers. Operational factors, such as unbalanced cargo loads and trallers with higher centers of gravity, are also more likely to be found in rollover accidents. 


\subsubsection{Tires}

Tire fallure is the second leading cause of erashes having mechanfcal defects as primary contributing factors (IIHS, 1985), and is thought by heavy-truck drivers to be the most fallure-prone part of the truck that affects safety (Regular Common Carrier Conference, 1987). Trucks carrying heavy loads may have underinflated or overheated tires, conditions likely to lead to blowout or fire, and often, loss of control.

\subsubsection{Override/Underride}

When accidents occur between large trucks and cars, the mismatch between truck and car bumper helghts leads to override and underride consequences. Override/underride accidents are more prevalent at night, when darkness reduces visibility for all drivers. This problem is more evident for certain trailer conflgurations, particularly platform traflers (MVA, 1985).

A comparison between fatal and nonfatal car-into-truck accidents shows that fatalities occur more frequently in underride accidents, including many from contact with the side of the truck. Trucks and trallers with devices to prevent underride were more likely to be involved in nonfatal accidents, showing the value of such protection (MVMA, 1985).

\subsubsection{Truck Occupant Protection}

Fewer than 1 percent of all medium- and heavy-truck occupants involved in accldents are kllled, and only 10 percent are injured. Nevertheless, truck driving is considered a relatively dangerous occupation when compared to other occupational fatality rates (NHTSA, 1987).

It 18 interesting to note that the mafority of truck drivers (76 percent) 1nvolved in accldents were not wearting seat belts at the time, based on analysis of NASS data. A truck driver vearing a seat belt is much less likely to be infured or will suffer a less severe injury in an accident, primarily because he is less likely to be thrown out of the cab by the 1mpact. FARS (1984) data Indicate that total or partial ejection was involved in 38 percent of combination-unit (tractor-trailer) truck occupant fatalities. Efection after an accident also occurred more frequently among truck occupants than 1t did among passenger car occupants (NATSA, 1987).

For those truck-occupant accident victims who remain in the cab, entrapment, cab crush, and contact with interlor surfaces pose serious consequences. A study of truck occupants in rural accidents identifled ejection and steering-assembly contact as the leading sources of truck occupant infury, followed by contact with the windshleld and the door area (Robinson, 1969). A study of infury patterns of fatally injured truck drivers concluded that severe abdominal injuries in combination with head and/or chest injurles were more likely among combination-unit truck drivers than among drivers of other truck types (Karlson, et al., 1977). The nature of these injuries suggests the steering wheel as particularly dangerous. The steering 
wheel was also 1dentified as the most prominent source of injury in an analysis of 124 accldents involvting Volvo trucks in Sweden (Anderson, et al., 1980).

Limited information is avallable on the relative safety of cab-over-engines (COE) and conventional cabs. There ts some indication that the risk of infury to a COE driver is slightly (15 percent) higher, and the risk of infury to the nontruck driver slightly lower, when a COE is involved (MVMA, 1985). FARS data show that COEs have a greater involvement in accidents in which a fatallty occurs as well as in accidents involving a truck-drfver fatallty. These findings are worthy of note since the advent of the COE design was motivated by Federal restrictions on overall length, which are no longer operative.

There have also been findings reported on the discomforts of prolonged exposure to driving and the potential for decreased driver performance and permanent harm to the body. The greatest concern among heavy-truck drivers is seat comfort, vibration, temperature, noise and fumes (Wyckoff, 1979). Drfvers report a higher frequency of hernla, back, k1dney and nervous problems when compared to the public. There is further evidence that those who spend more than half of their working lives driving are three times more likely to suffer back trouble than the rest of the population (Troup, 1978). The drivers surveyed for one study attributed 14 percent of their previous accidents to poor ride quality, and noted that vibration was more of a problem when vehicles were empty (Wilson and Horner, 1979). A Swedish research study also reports professlonal drfver complaints about nolse, exhaust, climate, uncomfortable seats and heavy lifting, leading to back and stomach trouble as well as heart and circulatory problems (Lipping, 1980;.

The Socfety of Automotive Englneers reports that truck driver exposure to notse is greatest during freeway hauls and that permanent hearing loss hazard may exist. They found that frequent use of radio or CB radlo can significantly 1ncrease this hazard (Reff, et al., 1980), although the use of a $C B$ radio has also been credited with increased driver alertness (Wyckoff, 1979).

Toxtc gases in heavy diesel truck cabs have also been found to exceed thresholds for significant occupational exposure concentration in many vehicles. Cab floor openings have been 1dentifled as a principal pathway for englne compartment gas transmission into the cab (Z1skind, et al., 1977).

\subsubsection{Safety Overstght}

Roadslde Inspections can serve as effective accident prevention measures. As shown in Figure 25, a State of Calffornla study found a clear inverse relationship between the number of roadside inspections and the number of truck at-fault accidents (Californla Highway Patrol, 1986). Although other factors undoubtedly influenced operations over this 10-year study pertod, the apparent correlation between increased enforcement and upgraded on-the-road safety is hard to 1gnore.

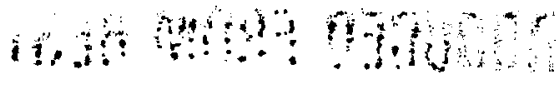

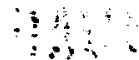


Flgure 25

Callfornla Truck Inspection and Truck Accident

Rate for Callfornia State Highways (1976-1985)
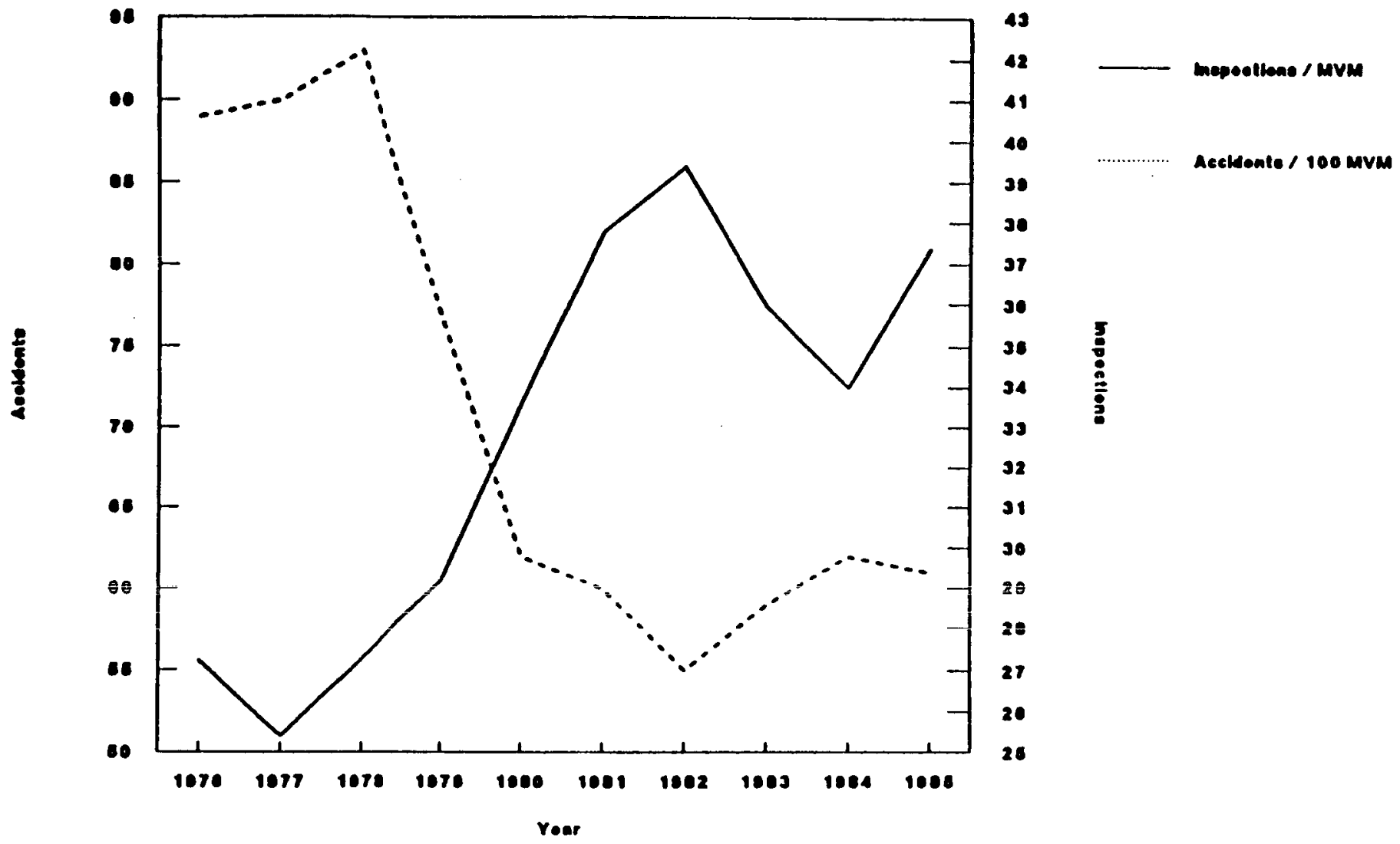

蛋䎡

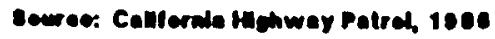


State terminal audits conducted as part of the MCSAP program also raise important carrier management safety 1ssues. In Arfzona, for instance, the three most common carrier violations are ( 1 ) failure to maintain driver qualification files, (2) hours-of-service violations, and (3) fallure to maintain inspection, repair, and maintenance records. Officlals famillar with Oregon's audit results concluded that carriers do not comply with the requirements because they typically do not elther know or understand the regulations as applied to thelr operations. Moreover, even when the regulations are understood, the cost of noncompliance is so low that is it not an effective deterrent. These findings point to the need for a better education and enforcement program.

In Michigan, a direct link has been established between driver qualifications, hours of service, and vehicle operations and comercial vehicle accidents. Making compliance with driver qualification procedures a direct responsibility of carriers has proven to be beneficial to accident prevention.

\subsubsection{Economic Factors}

The U.S. trucking Industry represents a diverse mix of carrlers, drivers, and truck owners operating with a broad range of safety practices and levels of management control. Some limited evidence links the amount of motor carrier investment in safety-related activities to the firm's overall financial condition. One study of for-hire, general freight carrfers found that the average carrfer that eventually goes bankrupt spends less on safety and malntenance, has older equipment, and depends more on owner-operators (Chow, 1987). However, the basis for this finding was not a comparison of accident rates to carrier profltability, but rather a comparison of expenditures that infer safety performance to a welghted combination of financial ratios. Moreover, studies of this kind are hampered by scarcity of Industry financial data maintained by the Interstate Comerce Comission (ICC), particularly for new entrants. Furthermore, ICC 1s eliminating requirements for detalled financlal reports from those carriers who must st111 submit records.

The question of whether the preponderance of drfver speeding is related to the method of compensation extended to drivers has been examined in one study. Drivers pald by the job have an economic incentive to speed, to produce more revenue-generating trips within a given time perfod. Based on analysis of NASS data, although speeding is prevalent across all segments of the carrier industry, speed is more frequently abused by ICC-exempt and for-hfre carriers. Leased drivers had the highest incldence of previous speeding violations, as well as previous license suspenstons and revocations. Leased drivers and drivers operating for ICC-exempt carriers were disproportionately involved in drunk driving accidents. The validity of these figures, however, is difficult to establish because the NASS data does not have well-defined driver or carrier classification categorles. Furchermore, It is difficult to delineate the class of driver on a spectfic trip, as the same driver could be leased or not leased in many different driver classifications and may drive during the year in many different types of operation. 


\subsubsection{Roadway Environment Considerations}

Like several of the vehicle-related 1ssues, roadway environment factors are often listed incidentally on many accldent reports. Typically, these factors make 1t easler for an accident to occur or create conditions that are unforglving of mlshaps or errors. Examples Include road design/geometry, weather, lighting conditions, traffic conflict opportunity, and operating speeds.

\subsubsection{Road Type}

The functional class of the roadway has a profound 1mpact on heavy-truck involvement rates for both fatal and non-fatal accidents (see Table 5). A similar relationship between rural/urban and interstate/other roadway fatality rates apppears in a corroborating study, although the magnitudes differ somewhat (Carsten, 1987).

Figure 26 depicts frequencles of heavy-truck accldents and fatal heavy-truck accidents by road classification. Of particular significance is the proportion of heavy-truck, fatal accldents (relative to all heavy-truck accidents) that occur on U.S. and State highways.

Some characteristics of these roads create the potential for severe accidents. For Instance, the presence or absence of median control has a profound influence on accident severfty. Fatalities are far more likely in accldents occurring on roads that are not physically divided and provide greater opportunfty for head-on collislons. Furthermore, roads with higher posted speed limits are more likely to be the site of fatal truck accidents.

\subsubsection{Lighting Cond1tions}

The 1mpact of lighting conditions on heavy-truck. accldent rates is not entirely known. Several studies find that the risk to truck safety is $1.5-2.0$ times greater at night than in the daytime (MVMA, 1985). Other studles report a higher truck accident rate in darkness during the sumer but a comparable accident rate for daylight and darkness during the winter season*, or find no

*A higher accident rate in darkness during the sumer may be due to the fact that darkness is more concentrated in the late-night/early-morning hours (when fatigue would be more apparent) in comparison to winter lighting conditions. 
Table 5. Single Trafler Veh1cular Accident Involvement Rates by Highway Functional Class

\begin{tabular}{|c|c|c|}
\hline \multirow[t]{2}{*}{ Functional Class } & \multicolumn{2}{|c|}{$\begin{array}{l}\text { Involvement Rate (per } 100 \text { million } \\
\text { vehicle-miles) }\end{array}$} \\
\hline & Fatal & Non-Fatal Injury \\
\hline $\begin{array}{l}\text { Rural interstate } \\
\text { Rural-other principal artery } \\
\text { Rural minor arterial } \\
\text { Rural major collector } \\
\text { Urban Interstate } \\
\text { Urban-other princlpal artery } \\
\text { Urban local }\end{array}$ & $\begin{array}{r}1.87 \\
3.80 \\
6.49 \\
13.67 \\
2.23 \\
9.52 \\
27.79\end{array}$ & $\begin{array}{r}25.53 \\
31.43 \\
41.65 \\
50.12 \\
52.73 \\
103.41 \\
55.59\end{array}$ \\
\hline
\end{tabular}

Source: Federal Highway Adminlstration, 1987. 
Figure 26

Truck Accidents by Trafficway

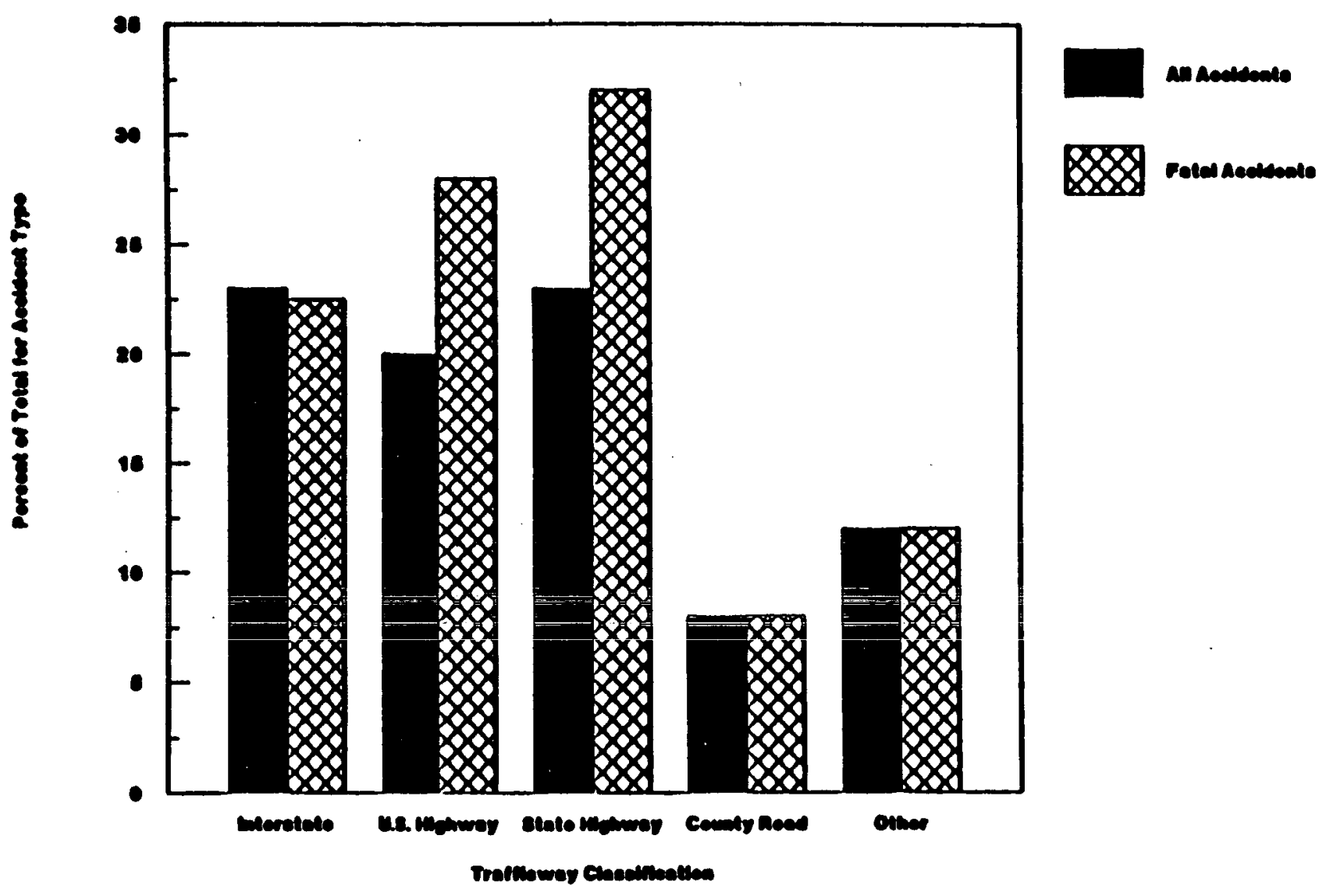


significant 1mpact of lighting conditions (Strandberg, 1987). However, an apparent correlation exists between lighting conditions and accident severity. Based on NASS and FARS analyses, 40 percent of fatal accidents involving heavy trucks occur at night, in contrast to 24 percent of all heavy-truck accidents.

\subsubsection{Sharing the Road}

Annual studies of heavy-truck accidents carried out by the California Highway Patrol place trucks at fault 43-53 percent of the time over the past 10 years (NHTSA, 1987). A European study reports that in accidents involving a heavy-truck and another vehicle, the driver of the other vehicle involved was mainly responsible 44 percent of the tlme (Theis, 1987). An American Automobile Association-sponsored study of multiple vehicle accidents involving heavy trucks in Michigan notes that the non-truck driver was considered at fault in 69 percent of fatal accidents and 49 percent of accidents requiring hospitalization. These results suggest that, in addition to developing policles directed at reducing aggressive and 1rresponsible behavior of truck drivers, emphasis must also be placed on improving public awareness of truck operations and safety requirements.

\subsubsection{Human Factors Pollcy Considerations for Improving Truck Safety}

A review of the previous discussion suggests several policy considerations related to the effects of human factors on the safety of nuclear waste transport by truck. It is apparent that the drfver is most frequently the key factor in determining whether or not a vehicular accident occurs under difficult driving conditions. A large number of heavy-truck drivers involved in accldents have poor driving records, including speeding offenses and other unsafe maneuvers that are major causes of accidents. Moreover, the correlation between drfvers under the influence of alcohol with Increased accident likelthood and sever1ty is a major safety concern. Accident studies and surveys 1ndicate that a major portion of the heavy-truck driver population has not recelved any driver training prior to going on the road. Young, inexperienced drivers are particularly susceptible to accident risk.

Fatigue can play a major role in accidents, particularly for young drivers during early shift hours and older drivers after extended shift length. Drivers of large trucks have shown significant increases in driving errors and decreases in driver alertness due to fatigue well within the current hours-of-service 1imlt. Greater understanding of the circadian rhythm (t1me-of-day) 1mpact on fatigue also suggests that current hours-of-service regulations and management assignment practices need additional examination.

Vehicle design and operating characteristics have a signfficant impact on safety. Brake systems are most in need of attention, with brake maintenance a principal concern. The prevention of jackknifing also deserves spectal attention. Handling and stability problems 1ncrease the likelthood of rollover. Tire condition and performance are also key factors in safely handling a big rig. Occurrences of override/underrlde, particularly at night, are common, suggesting that traller design and visibility are issues that warrant close attention. Truck occupants typically do not protect themselves by wearing seat belts. As a result, efection and contact with the cab intertor often occur, leading to a higher likelihood of a sertous injury or a 
fatality. Furthermore, truck operators are subjected to noise, vibration and other effects of prolonged truck driving which may lead to performance degradation and health impairment.

The roadway environment is recognized as a vital part of the safecy equation. U.S. and State h1ghways are disproportionately 1nvolved in fatal heavy-truck accidents, where the absence of sturdy median barriers has a profound impact on safety. The need for cars and trucks to share the roads safely deserves attention. The driving public must be made more fully aware of human factors in transportation and the potentially life-threatening consequences of a multiple-vehicle crash involving a heavy-truck. Further, in light of higher posted speed limits and increased speed varlation on roads, and the overinvolvement of speed in fatal accidents, DOE may wish to restrict truck speeds on certain roads.

Drivers who frequently or sometimes carry hazardous cargo reportedly drive at slightly lower average crulsing speeds and have better records with regard to moving violations and abusing the 10-hour driving limit (Wyckoff, 1979). These drivers tend to be slightly older and are less likely to drive while intoxicated.

On the other hand, drivers involved in the transport of hazardous cargo percelve they are less alert than other drfvers. They also report higher incidences of ulcers, nervousness and headaches. Furthermore, even though they reportedly drive fewer hours, these drivers have more complaints about long drfving hours and a helghtened concern over the safety of equipment they are using, particularly trallers (Wyckoff, 1979). Many of these symptoms may be due to the Increased stress assoclated with handing dangerous goods.

In the discussion to follow, additional background is provided in areas where truck transport policy development may be contemplated.

\subsubsection{Drtver Licensing}

Recent Pederal legislation has been directed at comercial vehicle operator 11censing through passage of the 1986 Motor Carrier Safery Act. The Commerclal Driver's License Program 1s currently under development with five key dates established as milestones for the implementation process. Effective July 1, 1987, it became 1llegal for a commerclal motor carrier driver to have more than one driver's 11cense. On July 15, 1988, standards for testing drivers and 1ssuing licenses were distributed, including a proviston requiring drivers intending to transport hazardous materlals to pass speclallzed tests. By January, 1989, a nationwide information clearinghouse for exchanging license and violation information muse be operable. After April 1, 1992, 1t will be 1llegal for a person to operate a commercial vehicle without passing the required written and driving tests. Finally " on September 30, 1993, States must adopt and administer programs to enforce testing and Ifcensing standards, accept the qualifications and penalties, or risk losing Federal highway funds.

Concerned safety officlals both in industry and government hope that this legislation provides for a program that can identify unqualified and irresponsible drivers and remove them irom the road. As noted by the schedule, however, the means to do so w1ll be phased in gradually over several 
years and will delay any 1mediate impact. Also, adequate monitoring of compliance and enforcement by the Federal Government will be required to make the legislation effective.

In fmplementing this program, concern has also been expressed over closing loopholes which presently allow commercial vehicle drivers considerable latitude in maintaining eliglbility. For example, under present Federal regulations, a commercial vehtcle driver may be disqualified only if h1s/her State license has been suspended or revoked, or if one of four types of traffic violations has been comitted. Furthermore, a driver who commits a spectfled disqualifying offense while driving a non-comercial vehicle or while driving a commercial vehicle off-duty, is not subject to disqualification. In addition, drivers who are not regularly employed by a motor carrfer and who drive commerctal vehicles on an occasional basis are exempt from several Federal qualification standards (NTSB, 1986).

\subsubsection{Driver Selection}

The task of driving a truck is considerably more demanding than operating a passenger car. Commercial vehtcle driving requires more attention and demands greater skills, both in normal driving situations and in responding to potentlal hazards (TRB, 1987). Large trucks are much less maneuverable than automoblles, and require greater distances for passing, stopping, turning and accelerating. As a result, a heavy-truck driver must possess the ab1lities to consistently anticlpate potential traffic conflicts and, when confronted with 1t, be able to take an effective evasive action. The identification of qualified drivers places considerable responsibllity on the part of carrier management to make approprlate hiring declstons.

According to Federal regulation, motor carrlers must require all driver applicants to complete a written application and within 30 days after hiring a driver, to inquire with State licensing authoritles and previous employers about the new employee's record during the preceding 3 years (NTSB, 1986). Although the written application content requirements are rather explicit, little guldance has been given concerning inquiries other than the requirement to maintain a record of the investigations.

An additional Federal requfrement is 1mposed on motor carriers to administer road tests to new drivers, for determining their fitness to handle the equipment to which they will be assigned. The test must be given in the type of vehicle the new driver will be operating, and must cover several aspects of truck operation. The regulations do not specify the qualification of the examiner or method of evaluation, and provide more latitude to owner-operators in that the road test must be given by a person (other than himself) who is supposedly competent to evaluate the driver's skills. Furthermore, exemptions may be granted to drivers who hold certain licenses or have passed the required road test administered by another company in the preceding three years.

Finally, the Federal regulations include a written "examination" requirement for all new drivers. This test conslsts of 66 questions, which are printed, along with the answers, in the Federal regulations. While taking the test, the driver may refer to the answer 11st. Furthermore, even if the driver scores poorly on the test, these results may not affect his or her 
qualifications, and employment may not be denied on the basis of a low score. owner-operators do not have to take the knowledge examination required of other drivers.

Aside from the obvious problems associated with the written examination requirements, in practice the regulations are often 1gnored or interpreted with conslderable lat1tude. Although the Commercial Driver's Iicense Program is likely to address some of the expressed concerns with driver qualifications, it will not be a direct substiture for a motor carrier's determination of whether a driver is sufficlently skilled to handle the exacting requirements of the type of work in which he/she will be engaged.

For this reason, wany carrlers concerned wth safe highway operations follow a careful driver hirling process that often 1nvolves referral, interviews, background checks on employment and driving records, and pre-employment physicals. Such care reflects a corporate management philosophy that not everyone is capable of operating a heavy I1g. One company has adopted the use of psychological testing to assist in determining the applicants who have the coordination, physical capability and mental attitude to handle a tractor-trailer comblnation (OTA, 1988). It has found a very strong correlation between these evaluative procedures and driver performance after hiring. This carrfer's comitment to a sophisticated driver selection process contrasts with findings from a study of carriers in the Pacific Northwest which showed that $35 \%$ of firms performed unsatisfactorily in qualifying their drivers.

While attempts to develop more stringent screening procedures is es:couraging, economic pressure on the industry is working to hamper this progress. The Department of Labor reports that the truck driving work force is expected to increase 177 by 1995, placing truck driving among the 37 fastest growling occupations, out of 500 studled (NTSB, 1986).

At the same tine, Industry analysts forecast that finding qualified truck drivers will become more difficult over the next decade, with a 307 reduction In the driver pool expected by 1992. This reduction will be due to retirements, drug screentng, tighter Federal driver requirements and licensing standards, a shrinking natlonal labor force, and the perception that truck driving is a high-stress job requiring excessive time away from home (Winsor, 1987).

Thus, although the Importance of the driver selection process in screening out unqualified drivers in advance is well recognized by many carrfers, unless the entire industry uses unfformly stingent driver selection practices, problem drivers will continue to enter the work force in great numbers. They wll merely be reshuffled to less safety-consclous firms within the 1adustry, creating a large group of high-risk motor carriers.

\subsubsection{Alcohol and Drug Use Among Prospect1ve and Current Drivers}

Currently, the Federal Motor Carrier Safety Regulations prohibit possession or use of an intoxicating beverage or drug while on duty, and from consuming or being under the influence of an intoxicating beverage within four hours before going on duty. Furthermore, a person is not qualified to drive if he/she has a current clinical diagnosis of alcoholism or drug dependency. 
These rules were promulgated based on the knowledge that driving while intoxicated or under the influence of drugs is directly assoctated with a degradation in driving performance. While the human response to the ingestion of drugs and alcohol varles depending on characteristics of the individual and environment (Drew, et al., 1959), it has been demonstrated that, for the majortty of subjects, human performance decreases at BAC (blood-alcohol concentration) levels of 0.05 percent or below*. Epidemiological studies also indicate that the risk of being involved, as well as at-fault, in a motor vehicle accident begin increasing at low BAC levels (TRB, 1987). This is in contrast to a legal standard for intoxification in highway driving which is currently set at 0.10 BAC in most States.

The basis for much of the previously cited research findings has been aucomob1le, rather than heavy-truck, driving performance. The transferability of these findings to heavy-truck drivers, who operate a different vehicle and who drive as a profession, warrants some consideration. Previous studies suggest that although more skllled pergons are better able to compensate for the effects of alcohol than Individuals who are less skilled, even skilled drivers show a decreased ab1lity to handle divided-action tasks at low BAC levels. Unfortunately, divided-action tasks are much more prevalent in a potential accident situation. Furthermore, as noted previously, many heavy-truck drfvers have not recelved prior training and have had such little on-the-road experlence, that they should not be considered skilled drivers as it relates to this discussion.

Recognizing the dangers of drug and alcohol use in the driver work force, . many carrlers have started to require pre-employment drug and alcohol testing. When one company started a drug-alcohol testing program two years ago, $15 \%$ of the applicants tested positive in the first year; a vear later, only $8 \%$ of applicants tested positive (OTA, 1988). Th1s company had sent a signal to prospective drfvers that they need not apply if they have a drug or alcohol problem; however, such individuals are not precluded from seeking employment as a driver for other carriers with less stringent screening policles. This concern is substantiated from the results of a carrier screening applicants in the Midwest, where $1 t$ was reported that $47 \%$ of the applicants had positive drug screens (Land1s, 1986).

The drug problem among employees may also be more entrenched than originally acknowledged. The safety director of a motor carrfer, while making spot checks of his company's tractors, found evidence of marifuana use; a subsequent investigation led to the discharge of $50 \%$ of the drivers at the terminal 1nvolved. In another instance, a laboratory which performs drug screening for several major carriers found that even for repeat examinations, 13-18\% of the tests were positive. In some cases, th1s occurred despite the fact that employees were given $30-60$ days advance notice that the tests were to be conducted (OTA, 1988).

Establishing formal procedures for perlodic drug and alcohol testing of employees has been the subject of much debate. Many motor carriers conduct testing on a calendar basis for all employees; others test a sample of employees. An agreement between carrier management and the International

*The most widely used measure of blood-alcohol concentration is the grams of alcohol per milliliter of blood, and is expressed as "percent BAC" (TRB, 1987). 
Brotherhood of Teamsters, reached in 1984, provides guidelines for periodic drug and alcohol testing. Members can be tested during thelr recurrent DOT physical examinations and when probable cause can be established from appearance, behavfor, speech or breath odor of an employee (TRB, 1987). Although the Teamsters represent many drivers working for large trucking operations, the vast majority of drivers are not subfect to this agreement. It has been estimated that carriers of sufficlent size to mount their own alcohol and drug abuse programs are responstble for less than one-third of the heavy trucks using the highways. To the extent that independents contract wth larger carrfers, however, they fall under the company's pollcy.

In a survey of 1,762 truck drivers conducted recently in Florida, $33 \%$ of the drivers reported belng previously tested for alcohol and $38 z$ reported being previousiy tested for drugs by the company they were presently driving for or to which they were currently leased. Owrier-operators reported the lowest frequency, $29 \%$ and $31 \%$ for company alcohol and drugs tests, respectively. Drivers working for for-hire carrlers reported the largest percentage of prior testing. Over $25 z$ of the drivers surveyed also reported having taken a lie detector test administered by the company they were driving for or to which they were leased. Of the drivers surveyed, 737 also stated they would approve mandatory random alcohol and drug testing by employers (Regular Common Carrier Conference, 1987).

Part of the concern over alcohol and drug testing is the rellability of the testing methods. Even the most accurate tests, which are also the most expensive ( $\$ 30-\$ 125)$, produce an error of $2-3$ percent ffor non-drug users wh1le passing up to 10 percent of drug users tested. Because of the likelihood of false readings, laboratory experts urge a follow-up test. However, many cost-consclous employers are not willing to invest these additional resources. Those more concerned about the Individual share 1nformation with the applicant and are willing to re-evaluate the applicant if he or she wants to take a second test at persorial expense.

One carrier has implemented a novel policy to resolve any differences in test results. If the first test is positive, the applicant is informed. If the applicant believes the test results are inaccurate, he pays for a confirmation test. Should the conflrmation test be negative, the company relmburses the applicant and considers him for employment (Borzo, 1987).

Some carriers are also showlng sensitivity to the counseling needs of drug and alcohol users. One carrler's employees are glven a drug test as part of their annual physical examination. They are notified of their scheduled appointment 30 days in advance. If a driver notifies management prior to the physical that he has a drug or alcohol problem, the company assists the employee in obtaining treatment. The firm belleves if an employee is able to admit to a problem, it has a responsibility to help him out, and that the employee has valuable characteristics if he can come forward under such clrcumstances. There 13 also a provision in the Teamsters agreement which permits an employee found to be under the Influence to take a leave of absence to undergo treatment (OTA, 1988).

More stringent methods for alcohol detection of truck drivers while on the road has also been discussed as a public enforcement measure. A recent. study conducted by the Transportation Research Board concluded that the technical abllity to detect and measure $B A C$ levels of less than 0.05 is 
avallable with current screening and testing devices. However, the legal ability of public authorities to enforce a low BAC standard with breath-screening devices has not been adfudicated at a definftive level. Should the ability to do so survive legal scrutiny, cost-effective enforcement could be carrled out by administering screening of drivers at truck weigh stations and as part of vehicle safety inspections, along with mandatory blood tests following infury-producing accidents. TRB estimates that vigorous enforcement of this kind would save between 80-140 lives annually at a minimum BAC level of $0.10,110-190$ lives at a 0.04 BAC threshold, and 130-250 lives by enforcing a limit of $0.00 \mathrm{BAC}$. The total public and private costs for enforcement at each level 18 estimated at $\$ 30$ million, $\$ 40$ million and $\$ 50$ million, respectively (TRB, 1987).

DOT has recently proposed to disqualify both interstate and intrastate truck drfvers found to have an alcohol concentration above 0.04 . First time violators would be subject to a one-year disqualification, while a second violation would result in a lifetime disqualification.

\subsubsection{Management Approach}

Driver attitude is thought by many to be a major factor influencing truck safery. A company's management can influence the employee work environment regarding safety. It is expected that if a carrfer promotes safety in all of its activities and rewards safe practices, this will have an effect on a driver's perception of safety as a major fob responsibility and his self-image as a professional, accountable for the safe operation of his vehicle.

One large motor carrier has determined that if the company's top management does not demonstrate a commltment to safety, then the organization will not be comitted to safety efther (OTA, 1988). This firm has adopted a formal corporate approach to safety. The focal points of 1ts program include (1) driver selection, (2) driver training, (3) driver conditioning, and (4) managing the driver.

Communication is an important ingredient at another firm. For instance, rotational discussion groups are held between management and drivers to solicit organizational 1nput. Not only does this show the driver that his opinion is valued by the organization, it also provides management with constructive feedback on operations. A third firm also has a considerable amount of communication with its personnel. The firm says that greater rapport between labor and management results in extensive agreement on where the organization 18 going and how it is golng to get there. Many carrlers have also structured varfous incentive programs to promote safety among their employees.

Should management practice a policy of creating an environment which does not compromise safety, this may entall balancing regulatory requirements and the quality of service offered to customers. The DOT hours-of-service rules combined with a movement in the economy towards just-in-time deliveries makes meeting these constraints a formldable challenge. One company is approaching this problem openly by informing customers that such trade-offs exist and that safety is a cost and concern relative to delivery timeliness. The American Trucking Associations (ATA) also advocate placing responstbility on shippers for demanding that truckers drive longer or faster than the law requires to 
deliver goods. Another expert assigns blame to brokers who often place constraints on both shippers and carriers for their own benef1t (OTA, 1988).

What makes this problem so complex in today's trucking industry is the Intense competition for frelght. All carrlers have on-going expenses and must have continuous revenues to meet them. Thus, the economic incentive for carriers to push drivers to the limit (and beyond) is quite strong as they attempt to attain a sufficlent volume of business by employing all avallable truck capacity whenever necessary.

The management approach to safety also affects the relationship between a company dispatcher and driver. At one firm for instance, if a driver calls in to the dispatcher Indicating that he is too tired to continue and that he needs to pull over, the dispatcher will not contest this request unless it becomes a chronic problem with the same 1ndividual. Th1s is in contrast to other companles where the dispatcher w1ll threaten to clte a driver for not meeting his assigned schedule (OTA, 1988).

Drivers complain that shippers and dispatchers often push hard for unrealistic delivery schedules that violate regulations. Currently, an oversupply of carriers exist, providing an environment in which shippers can shop around until they find a carrler wlllng to take a load on the shipper's terms. Under the circumstances, drivers feel it is unfair that they are held solely responsible for violations or accidents. The State of Rhode Island has acknowledged this 1nequity and 1 s starting to spread the responsibility through the imposition of fines and citations upon motor carrfer owners whenever their drivers are cited (OTA, 1988). At least one expert finds that drivers leel less pressured to take overloads in Staces where this change in policy has occurred.

\subsubsection{Driver Training}

Previous accident data analysis shows that truck drivers involved in accidents frequently lack formal training. This 1ssue is recognized as requiring prfortty attention by the industry.

At present, there is no Bederal requirement that drivers of heavy trucks recelve any degree of formal tralning, nor is there a single state which Imposes a training requirement for all drivers of heavy trucks (NTSB, 1986). Federal regulations establish qualifications on the basis of whether a person can safely operate the vehicle and secure the load being carried, which can be acquired through tralning or experlence. Motor carriers do not impose training requirements, and often require applicants to have a minimum of two years of on-the-road experlence 1rrespective of prior training. Th1s poses difficulties for graduates of accredited tralning programs since the only way to meet this requirement is to drive for a firm not possessing such a requirement.

Pormal truck drfver education is avallable through proprietary truck driver training schools, non-profit publlc education institutions and in-house motor carrier training programs. The number of training programs are estlmated at around 200, with fewet than 10 being in-house programs. Iution ranges from $\$ 350-\$ 5,000$. There are also wide varfations in course length, qualifications of the instructors, student/teacher ratio and, wost importantly, time spent in and around the cab (NTSB, 1986). 
Truck driver training schools may be subject to oversight from varlous licensing and accrediting bodles. Some States, such as Maryland, Pennsylvanla and Indlana, require the licensing. of driver training schools, although different agencies are assigned this oversight responstbility. Although these authorities often establish a minimum number of course hours, requirements concerning course content are usually not spectfled (NTSB, 1986). Some schools have been accredited by the Natfonal Assoctation of Trade and Technical Schools (NATTS) or the National Home Study Counc1l (NHSC). However, the vast majorlty of programs have not been accredited by efther organization.

In an effort to establish a set of standards for truck driver training, in 1984 DOT 1ssued proposed minimum standards for training tractor-trailer drivers. The standards call for a minimum 320-hour course, lasting eight weeks if taken on a full-time basis. Course content should include basic operation, safe operating practices, advanced operating practices, vehicle maintenance and non-vehicle activitles. The standards also cover instructor quallfications, school facilfties, graduation requirements and student placement. Although a truck driver training school can develop its own curriculum around these standards, in 1986 the Office of Motor Carriers published a ready-made curriculum, entitled Model Curriculum for Training Tractor-Tra1ler Drivers. Included in this document are instructions for the school adminlstrator, instructor and student. Unfortunately, these standards cannot be used for evaluating existing schools until their validity has been tested with actual schools and students.

Concurrent with these developments, the trucking industry has been taking steps to promote effective training. The Trucking Industry Alliance was established in 1983 as an informal coalition of individuals and groups in trucking and related industrles. The Alliance, in turn, established the Professional Truck Driver Institute of America (PTDIA). In an effort to define acceptable training standards, the PTDIA is in the process of certfying drfver tralning programs. The PTDIA is funded entirely by voluneary industry contributions.

In instances where in-house training actfvitles have been carrled out, the results are encouraging. In 1980, a large, general commoditfes motor carrler 1mplemented a training program whereby all new drivers are instructed In the safe handing of the vehicle and cargo. Since these training efforts were undertaken, the firm has reported a $13.5 \%$ decrease in ine-haul accident frequency, despite a $36.8 \%$ 1ncrease in line-haul mileage. In another case, a trucking firm's comitment to training led to the provision of a curriculum, equipment, instructors and course evaluations as afds to outside training schools (OTA, 1988).

The Insurance Industry has also particlpated in the development of training programs to promote safe driving behavior. One insurance carrier has developed a five-day seminar, open to driver trainers, safety and maintenance supervisors, and management personnel of fleet polfcyholders. It includes both classroom and behind-the-wheel exposure. Of several fleets' safety records examined before and after recelving training, reductions in accident frequency and loss rate per vehicle were conslstently reported.

Some discussion has also been raised concerning the development of a truck drfver apprenticeship program. The reasoning behind this proposal is that qualified supervision can help ensure that a new driver develops safe 
driving habits. In the Netherlands, for example, new drivers undergo a two-year apprenticeship (NTSB, 1986).

There is no currently organized apprenticeship program for heavy-truck drivers in the Unfted States, although the 1ssue has been raised in the past. In 1971 , DOT Invited comment on proposed apprenticeship programs that would have enabled persons less than 21 years of age to operate commercial vehicles. Th1s proposed rulemaking was subsequently closed without action.

Continuous training of current employees is also important not only to keep drivers up to date, but to identify bad hablts which may have developed over time. For example, research in Europe has shown how little perception even experfenced drivers have of their actual speed when they are in a monotonous or repetitive driving situation. Problems with speed perception can be particularly acute when a drfver leaves the Interstate system and begins to operate on two-lane roads where speed Iimlt, access, median control and signage are quite different.

Some carriers are also concerned about keeping drivers physically fit to handle the rigors of the fob. One firm believes that physical conditioning, welght control and aeroblc capactty are keys to reducling problems assoclated with fatigue and stress. Another is installing a conditioning program avallable nationwide for their line-haul drivers to encourage the right physical and mental condition to handle the unexpected events that dafly confront their drivers.

\subsubsection{Sharing the Road with the Driving Public}

Many truckers rightly claim that most automobile drivers are not fully aware of the approprlate ways to share the roads with trucks. For instance, because of the Increased stopping distances assoclated with truck braking, truck drivers in congested areas try to leave enough room between themselves and other vehicles to allow for a complete stop. However, automobile drivers often eliminate this space by cutting in front of trucks. Moreover, if the truck subsequently hits the rear of the car, the truck driver may be cited for the accldent. Thus, while many unsafe truck drivers are undeniably operating on the nation's roads, there are also many poorly qualifled car drivers sharing these highways.

An education program directed at the driving public could enhance awareness of safety 1ssues related to sharing the road with trucks. States, such as Tennessee, are considering reorganizing their licensing programs to include materlal and questions on truck aafety. They are also contemplating running a continuous showing of a tape on sharing the road with big trucks to people while wafting to obtaln driver 11censes.

Education programs to better inform small carriers about road safety have also been developed. Avallable through the Natlonal Safety Counctl and ATA, these materials describe how a carrier as small as a ten-person trucking company can Implement a responsible safety program. 


\subsubsection{Hours of Service}

The hours of service rules in effect today are essentially the same as those promulgated in 1937 and 1938 by the ICC*. The regulations prohtbit carriers from requiring or permitting any driver to "drive" more than 10 hours, or to be "on duty" more than 15 hours in any (but not every) 24 consecutive hour period. Drivers are theoretically guaranteed 8 consecutive hours off-duty during that time period. In addition, drivers are prohibited from accumulating more than 60 on-duty hours in any week, or 70 on-duty hours in any perfod of elght consecutive days.

Extremely difficult to enforce, this rule is subject to problems ranging from blatant abuse to loose interpretations of "on duty" and "off duty." For example, tiring and strenuous activities, such as loading and unloading, done by the driver, are not considered "driving" tlme, although they clearly contribute to fatigue. Furthermore, elght hours of "off duty" time do not afford drivers adequate time to travel to and from their jobs, eat, bathe, and attend to life's other requirements, and to obtain elght hours of undisturbed sleep. Moreover, the 15 hour on-duty period can be interrupted durfing the course of a driver's overall tour for any number of hours if thelr employers "relleve" them of on-duty status for meals, rest breaks, or while their vehlcles are being loaded and unloaded. Finally, the carrier-wide practice of requiring a driver to stand around a terminal in an "off-duty" status awaiting a work assignment contributes to fatigue prior to the tour of duty ever beginning.

First the ICC and subsequently DOT have openly acknowledged that the hours-of-service rules have been subjected to abusive practices. In 1972, the Bureau of Motor Carrier Safety (BMCS) in DOT inftiated a comprehensive study of the relationshfp between dangerous levels of fatigue among truck drivers and the current hours-of-service regulatfons (Harris and Mackle, 1972). The report compiled and analyzed scientific and medical data reflecting driver performance and physlological responses collected during 195 truck and bus runs. A total of 1,550 hours of continuous data were obtafined and analyzed on 62,000 miles of highway truck travel in all parts of the country, and in all weather and traffic conditions. The study concluded the following:

The general findings of this study... Indicate that driver performance deterforates, drfver alertness diminishes, rest breaks become less effective, and accldent probabllity increases, all within the current 10-hour daily Ifmitation on driving time. It (the regulation) is further at odds with a good deal of anecdotal evidence from the drivers to the effect that they do suffer from considerable fatigue but are unwilling to admit 1t because of the feared economic consequences. Th1s situation is likely to remain as long as drivers are rewarded, as most are now, in direct proportion to the amount of time spent on the highway. In our opinton, this places economic reward in direct conflict with highway safety.

Trucking is not subfect to the Fafr Labor Standards Act. Carriers do not have to pay time-and-a-half for a greater than 40-hour work week. This creates an incentive for a carrier to hire the fewest drivers possible and to have them work the longest hours possible in order to maximize profit. 
As a result of this study, BMCS admitted that the hours-of-service rules were unsatisfactory and in need of revision, but it did not take any formal regulatory action at that time. The fust completed study had concentrated on scheduled relay operations of large common carriers whose drivers were able to plan their rest. BMCS acknowledged that further research was needed on non-regular route drivers who often could not predict when they would be assigned to driving tasks.

In 1978, BMCS 1ssued the results of the second phase of their fatigue study. As expected, it was found that relay drivers operating on an irregular schedule suffered greater subjective fatigue, physlological stress, and performance degradation than drivers who work a simllar number of hours on a regular schedule. It was also reported that fatigue effects are evident after about elght hours of relay truck driving when the schedule was regular and considerably earlier when the schedule was 1rregular. In addition, cargo loading was found to increase the severity of fatigue associated with 1rregular working schedules (Mackie and Miller, 1978). Finally, the reported findings were considered conservative since the drivers in the study were afforded the opportunity to obtain elght hours of sleep each night, clearly not always the case under conditions of uncertain and changing schedules.

In a separate, concurrent study of accldent data, it was found that the number of driving hours alone was not related to frequency or severity of truck accidents. However, the combination of the driving and non-driving time may be related to driver fatigue and play a role in accident occurrence (Safety Management Inst1tute, 1978).

Following the results of these studies, BMCS subsequently issued a Notice of Proposed Rulemaking (NPRM) and conducted public hearings in several clties around the country. By the end of 1978, BMCS had accumulated what $1 t$ consldered to be sufficlent information to justify amending the hours-of-service regulations.

In 1981, however, the agency published a notice terminating the rulemaking action and closing the docket, citing the absence of a direct relationship between the hours of service rules and accidents. Also, in 1981 , BMCS commissioned an economic study of the cost of modifying the hours of service rules. The projected costs of each of the government's three major options were considered to be significantly greater than the projected benefits (Booz, Allen and Hamliton, 1981). The relationship between the results of this study and the closing of the NPRM is evident.

\subsubsection{Sleep Needs}

It is well known in the sclentific literature that human performance is best at moderate levels of arousal. At low levels, insufficient energy exists to make informed decisions; at high levels, actions may be frequent, but 111-directed (Allnute, 1983). Fatigue 1s typlcally assoclated with low levels of arousal, and can be brought on by three categorles of stress: (1) physical (e.g., temperature, vibration, etc.); (2) physiological (e.g., drugs and alcohol, 1rregular eating habits, etc.); and (3) psychological (e.g., fear, Erustration, economic pressure, etc.). A distinction is sometimes made between single-trip fatigue, where an opportunity for recovery may exist, cumulative fatigue, in which recovery time between trips is not adequate, and 
chronic fatigue, which usually requires medical assistance. The behavioral symptoms of all three types of fatigue are similar, however.

Off-duty time as spectfied in the regulations does not always translate into sleep or rest time as 1 was intended. This results in part from the manner in which the body functions biologically. Sleep researchers have shown that the body typically functions according to a circadian, or 24 hour, cycle. Thus, when a driver starts his off-duty time, he may not be blologically ready to rest. As an example, a driver who begins a driving day at 6:00 a.m. must stop to rest at 4:00 p.m., according to the regulations. However, his circadian cycle probably is not tuned for him to begin prolonged rest. The driver is likely to take a nap eventually, but will hit the road again at 12:00 midnight, fust when his circadian cycle prepares his body for sleep. Military research has shown that no amount of mental or physical conditioning can prepare people to withstand sleep deprivation. The brain will lapse into sleep for seconds at a time, especially under conditions such as driving. Circadian rhythm factors may explain the disproportlonate share of accidents that occur in the early morning hours between midnight and 6:00 a.m.

In a survey of truck drivers questioned about drowsiness, approximately $80 \%$ reported they had 'slept' or often felt 'drowsy' at the wheel (Endou, et al., 1979). Common misapprehension assoclates fatigue with the length of time one has been on duty. However, as noted prevlously, a conslderable number of transport accidents occur early into the shift, particularly if the shift began in the early a.m. hours. According to sleep researchers, this is a time when a person is particularly vulnerable because there are three things working against alertness: (1) a low polnt in the circadian cycle, (2) a low body temperature and metabolic rate, and (3) sleep inertia. With these factors working against alertness, reaction tlmes in this perlod can double or triple, and sleep researchers actually refer to this time as the "forbidden zone." They argue that a perfod of decreased alertness also occurs in the mid-afternoon. If driving under the Influence, the Impalring effects of drugs or alcohol are also greatly augmented in a sleepy person (Dinges, 1987).

There is recent evidence that the assignment of a secondary task can have a beneficial effect on truck drfver performance (Drory, 1985). Th1s was most apparent when the secondary task involved volce communication. In this instance, volce communication served as a stimulus without causing a distraction to the basic driving task. Another accldent mitigation measure directed at fatigue is the installation of rumble strips on the shoulders of highways to provide an audible warning to inattentive drivers. A California study reported a $49 \%$ reduction in "drffted off road" accidents where the strips had been installed (TR News, 1988).

\subsubsection{On-Board Recording Devices}

The use of on-board recording devices as a mechanism for 1mproving compliance with hours of service rules has been proposed by safety advocates. Units are currently avallable that can evaluate the engine speed, road surface, temperature, tfre pressure, ofl pressure, cooling system, and other operating elements. Although the information which 13 collected permits the examination of distance traveled, driving time, breaks, dally rest periods and speed limlt compliance, carriers have been purchasing these systems to manage fuel efficlency. One firm reports that an on-board device pays for itself in 
six months through cost savings in fuel, maintenance and driver time (reduced paperiork requirements). It also serves to streamline the preparation of reports which must be filed regularly with oversight agencles, which has led to DOT accepting recording device output in lieu of logbooks for some carriers. Thus, an economic incentive exists for management of firms for investing in a device that could also be used to enhance safety (OTA, 1988).

Th1s same firm's experlence with galning acceptance from drivers in installing these devices is instructive. First, management held driver seminars to help drivers understand how and why the organization was going to use the recorders. After inftial resistance, drivers understood that the recorders provide a mechanism for proving their innocence when a delivery is late because they were following the rules. The system also includes an alarm that activates if a driver runs at speeds greater than 55 mph for more than one minute. If the driver does not reduce speed within a short time period, he is considered to have a speeding violation by the company and can be disciplined. This speed determination capability has made the installation of road speed governors unnecessary (OTA, 1988).

A simflar experfence with on-board recording devices has been reported by another large transport company. Since the devices were installed, preliminary results show that fuel mileage has already increased by $12 z$, average drive tire mileage is up to 270,000 miles and brake Iining life has increased. Insurance rates have also dropped. To gain acceptance among drivers, the company inltiated an incentive plan based on the driver's performance evaluation. From information gathered by the recording device, each driver recelved a grade based on a cumulative average of all major functions on the trip (e.8., maximum speed, engine revolutions, idle time, etc.). The incentive plan pays drivers an extra 2 cents a mile if they receive a performance grade of 10 , and one cent per mile for a grade of 9 . Drfvers now prefer trucks equipped with the devices so that they can earn extra compensation (Private L1ne, 1986).

In the courts recently, an insurance case was settled on the basis that the tape from an onboard recording device showed that a truck driver had geared down in anticlpation of an automoblle driver cutting in front of him to enter a ramp. The truck hit the car, and the driver sued. The device showed that the truck driver did, in fact, gear down, but could not do so fast enough to prevent the accident. The automoblle driver lost the case (OTA, 1988).

While several European countries currently require on-board recording devices in the1r heavy trucks, Installation of these devices on trucks in the U.S. remains voluntary although their use is 1ncreasing. Several policy questions related to recorders remain unresolved, and the devices still need to have their accuracy and reslstance to tampering verifled and upgraded. If on-board recording devices were to become mandatory, who would be responsible for enforcing the hours-of-service regulations? Would the onus be on carrier management to monitor the tape and be responsible for compliance? Would FHWA implement a mandatory audit on a regular basis attesting that the carrier reviewed the electrontc logs and enforced the regulations? How would such a system work for small carriers and owner-operators?

Taripering has been singled out as a particular concern. Previuis research on the effectiveness of technological 1nnovation and the man-machine interface, suggests that if a system design is unacceptable to the user, 
regardless of engineering performance and reliabllity, man will underuse 1t, misuse 1t, or even sabotage it (Price, 1987).

\subsubsection{Speeding}

Prfor analyses indicates that higher speeds are assoclated with increased accldent likelihood and severity. Many common carriers have chosen to limit the speed at which their tractors can be operated through the installation of road speed governors. These devices prevent the englne from generating power in excess of a specified rpm; consequently, unauthorized speeding is curtailed. It is unclear, however, whether this practice has been motivated more by fuel economy savings or a corporate concern for safety. If not tampered with, these devices are quite effective in keeping speed close to the legal limit. However, mandatory speed governors may contribute to driver boredom, an issue that requires further investigation.

Some States, such as Virginia, have trled to control speeding by passing laws outlawing the use of radar detectors. The sole function of a radar detector is to recognize when a law enforcement officer is measuring the vehicle's speed. Therefore, it can be inferred that the prevalence of radar detectors in the trucking industry is an indication of the potential for abusing speed limits. A recent study conducted by IIHS and Goodson Englneering found that radar detectors encourage speeding, with the vehicles traveling fastest belng most ilkely to be equipped with the devices. They also reported that of all vehicles on the road, tractor-traflers are the most likely to be equipped with radar detectors (IIHS, 1987). A recent survey conducted by the Owner-Operators Independent Drivers Association of America Indicated that $69 \%$ of vehicles driven by owner-operators are equipped with radar detectors. A separate survey of truckers in Florida found that $79 \%$ use radar detectors (Regular Common Carrier Conference, 1987).

The use of detectable and non-detectable radar by enforcement officers countered by the use of radar detectors and radar jaming devices by drivers reflects the essence of the relationship between a cost-competitive market and the need to adopt and enforce adequate. safety standards. With the vast majortty of drivers compensated efther by the mile or by the job (Regular Common Carrier Conference, 1987), It is clearly in the driver's economic best interest to make each delivery as quickly as possible.

\subsection{HUMAN FACTORS IN RAIL SAFETY}

Although relatively little is known about human factors in rallroad operations in comparison to the trucking industry, reported findings are remarkably consistent. This information $1 \mathrm{~s}$ presented in the following discussion, and is organized according to simllar topic headings as in the truck section, wherever possible.

\subsubsection{Employee Negligence}

An Intensive investigation of train accidents in which employee negligence was a primary or contributing factor tdentifled several leading causes of negligence, listed below in order of priority (NTSB, 1972): 
1. Disregard of stop signal

2. Excessive speed in other. than yard limits

3. Switch 1mproperly aligned

4. Disregard of restricting stgnal

5. Fallure to secure or control by hand brake

6. Absence of man on or at leading car being pushed

7. Excessive speed or fallure to control in yard limits

8. Fallure to flag

9. Moving without orders or stgnals

10. Fatlure to clear switch or other tracks

Each of these 1tems represents human fallure in the performance of a function, although they represent different aspects of human involvement. Disregarding signals and yard movement infractlons reflect problems of judgment on the part of the engineer, for wh1ch back-up mechanisms or procedures are often weak, non-existent or unenforced. Hand brake fallures are often attributed to 1ts design and location. Switching problems may be reflectlve of the lack of cooperation and communication between the englneer and other members of the crew. Irrespective of the specific nature of each failure, NTSB concluded from 1ts study that the employee's attitude is a significant factor in the performance of a safe job.

\subsubsection{Drugs and Alcohol}

As in the case of the truck industry, it appears that the railroad industry is also plagued by significant drug and alcohol problems.

In 1978, a study of alcohol problems in the railroad industry concluded that roughly $20 \%$ of operating employees had elther consumed alcohol on the job, come to work affected by $1 t$, or suffered from off the job problems that could affect their on-the-job performance (R1ley, 1986). S1milar findings were reported from autopsies performed on 136 fatally infured rallroad employees over a seven-year perfod. In $16 z$ of the cases, slgniffcant levels of alcohol or drugs were present in the bloodstream.

What is disturbing about Federal rallroad regulation is that it is inconsistent with other modes with regard to substance abuse. Rafl regulations do not specify a pre-duty abstinence perlod, yet do establish a 0.04 percent blood alcohol IIm1t, and state that operators may not possess or use controlled substances or be impalred by them while on duty (Goldman, 1986). DOT has recently proposed more stringent rulemaking to prohtbit the use of controlled substances by any rallroad operating employee, whether on-duty or off-duty.

Recent leglslation has authorized rallroads to test employees for alcohol or drug impalrment after accidents or where there is fust cause. This is now routinely done for accidents in which there are fatallt1es, where hazardous materlal is spilled, and where human performance decrement is a probable cause (Goldwan, 1986). This legislation also lmposed pre-employment drug screening and created a provision for a railroad employee who has a substance abuse problem to come forward voluntartly, obtain medical treatment, and return to his former position following physician clearance. 
One major rallroad has experienced significant safety benefits from the 1mplementation of drug and alcohol testing. They reported a $66 \%$ decline in human factors accidents over an 18-month period, and lost time 1njuries declined by over $24 \%$. It is interesting to note that, at the outset, over $23 \%$ of employees tested positive, a figure which has declined substantially over time (Dempsey, 1986). Results like these have prompted DOT to propose a rule mandating random drug testing for all rallroad employees.

\subsubsection{Fatigue}

Limited studies of fatigue among rallroad operators report results which are entirely consistent with truck fatigue findings. It appears that train operators also suffer from circadian effects (Dinges, 1987).

The most documented findings to date were reported by researchers in West Germany, who studied 2,238 fallures by train operators to respond to warning swltches. A temporal analysis of these fallures revealed two peaks, one at 3:00 a.m. and the other at 2:00 p.m. (H1ldebrandt, et al., 1974).

\subsubsection{Sharing the Road}

Akin to the truck transport problem of big rigs sharing the road with passenger vehtcles is the problem of the interaction of trains and passenger cars at grade crossings. An alarming number of serfous accldents occur at grade crossings, comonly due to failure of the passenger car to operate safely. Several studies have been conducted examining the safety benefits of improved signage and other warning devices (Koziol and Mengert, 1978).

\subsection{HUMAN FACTORS IN MARINE TRANSPORT}

The scarcity of literature on human factors in marine transport is reflected in the IImfted scope of the following discussion.

\subsubsection{Drugs and Alcohol}

Iftle has been done to study the scale of the drug and alcohol problem in marlne transport. Coast Guard rules prohibit operation of a vessel in a negligent manner while intoxicated. No pre-duty drinking IImfts are prescribed nor is an Intoxication level spectfied (Goldman, 1986).

DOT has recently proposed a drug testing program for merchant marines that includes pre-employment, post-accident, random, reasonable cause and perlodic testing for employees as part of a comprehensive program that also includes education and rehabilitation. Under this program, an estimated 131,700 seamen would be subject to testing, including self-employed vessel operators. 


\subsubsection{P1lot Performance}

Waterway segments where vessel accidents have tended to occur are characterized by the presence of bridges, locks, narrow channel widths, and bends, intersections or junctions (Paramore, et al., 1979). Current has been shown to be the single most frequently cited causal factor in ramings and groundings, and has also been mentloned frequently in collision reports. More specificaliy, principal task problem areas were found to be imprecise or untimely 1dentification of current force and direction on the mother vessel and/or the tow. Although towboat personnel in particular have limited sources of Information and often rely on experfence, in general it was found that human error usually arose where improper control decisions and actions were made in situations where there was ilttle margin for error. 


\subsection{CONCLUSIONS AND POLICY RECOMMENDATIONS}

Based on avallable data and previous studies directed at human factors in transportation, it appears that human factors are likely to be a major cause of radloactive waste transport accidents, both loading and in-transit. Although the consequences of such accidents may be less severe, on the average, with transport accidents caused by other factors, uncertainties in the avallable accident databases and the public perception of the consequences associated with any radloactive accldent suggest that a formal DOE human factors research activity should be inltiated.

A review of previous 11terature and analysis of truck vehicular accident data have constructed a foundation on which to build policy directed at the safe transport of radioactive waste as 1 t relates to human factors. Although most of this work has focused on truck transport, and consequently more detalled policy recommendations can be directed at this mode, based on limited avallable Information, truck, rafl and marine transport appear to share some common problems which may require policy litervention.

In terms of container-related areas, these problems focus on securing valves, fittings and closures during the loading process, and making sure they remain snug throughout the in-transit portion of the trip; maintaining Intersal contalner pressure within safe limits; safe handing of radioactive materials during the loading process; and proper protection of the shipment from damage should a vehicular accident occur while in-transit.

The human tasks associated with the safe loading and transpor of radloactive wastes require personnel who are responsible, qualifled, and alert Individuals, with a positive attitude towards safety and a level of maturity commensurate with the hazardous nature of the materlal they are handling. It also requires a carrier management that has made a sincere comitment to safety in its operation, and has made every effort to comply with Federal safety regulation governing the transport of radioactive materials. Finally, it requires a vehicle design and operating environment that extends the margin of error so that when human errors occur, the opportunity to take a corrective action can be made prior to an accident occurrence.

In the discussion to follow, several policy recomendations are made which DOE may wish to consider. In many cases, DOE may not be the agency with jurladictional purview over the matter, although it would be expected that DOE would work in close cooperation with other agencies to effectuate change where such policy would provide clear safety benefits. It is also 1mportant to recognize that these policy recomendations are necessarily general, in keeping with the primary objective of this study as a scoping effort. Those policy areas which DOE would like to investigate more fully should be accompanied by more directed studies in the future. 


\subsection{POLICY RECOMENDATIONS}

\section{1 .1 Employee Selection and Hiring Practices}

Carriers must be held more accountable for their employee selection and hiring practices. Perhaps DOE should impose standards on prospective carriers of radioactive waste materials conceming the depth of their inquiries with prior employers of job applicants, qualifications of applicants to perform satisfactorily in fleld test sttuations, and pre-employment screening of applicants concerning their psychological state to handle the rigors of frelght transport operations.

Some help is on the way for the trucking mode with the recent passage of the Commercial Driver's License Program. If the original intent behind this legislation is met in a timely fashion, truck driver licensing practices will become more tightly controlled with uniform standards. However, steps must be taken as part of this process, or as a separate rulemaking inftiative, to close loopholes in driver disqualifications for violations occurring while in a non-commerctal vehicle, or in part-time or off-duty status.

\section{1 .2 Drugs and Alcohol}

Given the apparent widespread use of drugs and alcohol among truck and rall operating personnel, firm and declsive steps should be taken to respond to this growing problem. Measures such as mandatory drug and alcohol screening for applicants, and for employees as part of thelr perfodic DOT physical examinations deserve consideration. Screening of employees when probable cause can be established is also warranted. Random testing, although it may be effective in practice, must be approached with the legal Implications in mind.

There is sufficlent evidence that operator performance is impaired at BAC levels well below 0.10 . It is recommended that acceptable levels for truck drivers be reduced to 0.04 , corresponding to present levels for rallroad engineers. This will occur naturally if the DOT Secretary does not make a formal rulemaking by October 1988 .

\section{1 .3 Fat1gue}

Hours-of-service regulations, formulated well before the introduction of the Interstate highway system, changes in vehicle design and present economic conditions, have become outdated. DOT has been reluctant to set new standards due to potential adverse economic 1mpacts upon carriers. There are compelling reasons for DOT to reexamine the hours-of-service limits and to consider the issuance of new standards which are more consistent with current sleep research results and the present carrier operating environment. Sleep research suggests that an Individual's internal 24 hour clock governs human blological performance and behavior, yet the present rules do not constder this factor. However, care must be exercised so that current standards are not replaced with ones that also have loopholes which can be exploited by shippers, owners and operators. 
Programs are also needed to help management and drivers understand when drfvers are most vulnerable to accldents and how scheduling might be altered to reduce drfver vulnerability. A research program to develop simple, effective and inexpensive techniques to screen drivers who may have a sleep disorder could help ldentify the high (fatigue) risk driver. Moreover, the development of portable performance devices that detect, in a quick, reliable, and non-invasive manner, whether a person is reacting properly is a realistic long-term goal.

However, alertness devices may create an environment of false security. An operator, for instance, can be awakened by such a device, and conclude that he can continue driving since he is now awake. In another situation, the driver could feel tired but decide to continue driving because he could assume that the alertness device would awaken him if he did fall asleep. Drivers and management must understand that the driver remalns responsible for driving safely, regardless of the alds installed to help him.

\section{1 .4 Speeding and Other Moving V1olations}

On-board recording devices have been demonstrated to be a cost-effective management tool in the trucking Industry, leading to fuel economy, maintenance troubleshooting and paperwork reduction. Speed enforcement devices are also avallable in the rallroad industry. The use of on-board recording devices in a truck driver oversight capacity has been successful in the limited applications where this has been attempted. However, in each case, management approached this through a careful and open dialogue with drivers in order to minimize the potential adverse effects of installing these devices. Otherwise, the backlash from employees who have not been properly sensitized may give rise to tampering and abuse.

Consideration should be given to abolishing the use of radar detectors by trucks. These devices serve the single purpose of recognizing when an enforcement officer is measuring the vehicle's speed. Their active use clearly promotes excessive speeding, which has been previously assoclated with both increasing accident likelihood and severtty.

\section{1 .5 Operacor Tra1ning}

A more active Federal presence in the area of training 1 s urgently needed for truck, rall, and barge operators. In the case of trucking, Pederal requirements can be imposed that drivers of heavy trucks graduate from an accredited truck driver training program prior to being eligible for employment conslderation. To 1mplement such a policy, however, curriculum standards must be established and a proven accreditation process administered. Considerable progress has been made in this area with DOT proposed curriculum standards and the ongoing efforts of the PIDIA. To be effective, carrier management must also be willing to modify their hiring policy to accept training school graduates without on-the-road expertence. Carriers concerned about placing these drivers into the operation without prior experience can develop in-house apprentice programs. 
In the case of barge transport, real-time slmulation training for towboat navigation warrants serfous consideration. Glven the narrow safety margins in some domestic waterways and past practices of navigation primarily from experfence, navigation training is a rational policy initiative.

\subsubsection{Vehicle and Environment Factors}

Several aspects of vehicle design and malntenance can be enhanced to provide a greater margin of safety for operators. Braking system, vehicle handling and stabllity, tire and lighting (reflectorlzation) improvements would provide beneficlal effects on truck safety. Truck occupant protection and alertness can be improved through cab design, and improvements in ride quality (nolse, heat, vibration, etc.). Better instrumentation for vessel navigation is needed in barge transport. Brake design and cab warning devices have been suggested as emphasis areas in rall operations.

The operating environment could be enhanced through better cooperation and communication among users who share or interact on a transport facility. Cooperation and communication among raflroad crews, between vessels, particularly in blind situations, at railroad-roadway grade crossings, and between trucks and passenger vehtcles are emphasis areas. In the case of trucking, for example, this could take the form of education programs directed at creating an awareness of the handling and stability characteristics of trucks as well as the potential for severe damage that can be administered by truck mass in crash situations. It also suggests the 1mportance of using escort vehicles for radloactive waste shipments.

\subsubsection{Enforcement}

For any current and proposed standards to be effective, they require considerable public and private enforcement effort.

Government programs, such as MCSAP, are exemplary in terms of theis effectiveness in identifying vehicle defects and some driver violations, and plans are underway to extend this oversight to audits of carriers and personnel practices at frelght terminals. In many respects, however, this is a small portion of a much larger problem associated with ensuring compliance with Federal regulation. Qu1te frankly, without adequate enforcement, the intent of safety standards will not be met and may as well not be there at all.

To meet these growing requirements, it is likely that additional Inspectors will be needed. Increases in the penalties for non-compliance may also serve as encouragement to abide by operating rules.

Cooperation of carriers is also essential to the safety equation. Carrier management must adopt a company-wide comitment to safety. This should be conveyed to everyone in the organization as an inherent attitude around which performance is evaluated. In addition to applying internally to drivers and dispatchers, this philosophy must be transmitted to shippers and brokers. With all these parties involved, the likelihood of a safer operating environment will be considerably enhanced. 


\subsection{REFERENCES}

Allnutt, M., 1983. "Human Factors: Baslc Princlples," in Pllot Error, The Human Factors, edited by $R$. Hurst and $L$. Hurst, Granada Publishing.

Anderson, A., et al.., 1980. "Injuries in Trucks and the Effectiveness of Seat Belts," Proceedings of the 24th Conference of the American Association of Automot1ve Medicine.

Beflock, R., 1987. 1986 Motor Carrfer Safety Survey, Regular Comon Carrier Conference.

Booz, Allen and Hamilton, Inc., 1981. Assessment of the Impacts of Proposed Hours of Service Revisions, prepared for OMC, Report No. DTFH61-80-C-00088.

Borzo, G., 1987. "Motor Carriers Institute Pre-Employment Drug Tests," Trafflc World, June 15, 1987, p. 12.

Bureau of Motor Carrier Safety, 1979. 1976-1978 Analys1s of Motor Carrier Accidents Involving Vehicle Defects or Mechanical Faflure.

California Highway Patrol, 1987. Jolnt Legislative Report on Truck Safety, Report No. AB-2678.

California Highway Patrol, 1976. Critical Item Inspection Fact Sheet.

Carsten, n., 1987. "U.S. Accident Experfence of S1ngle and Double Trailer Combinations," Symposium on the Role of Heavy Freight Vehicles in Traffic Acc1dents, OECD, Vo1. 1, p. 2-80.

Chow, G., 1987. "Deregulation, Financial Condition and Safety in the General Frelght Trucking Industry," presented at the Northwestern University Conference on Economic Regulation and Safety.

Dempsey, W1lliam, 1986. President, Assoctation of Amerfcan Ra1lroads, Testimony before the Committee on Commerce, Sclence and Transportation, U.S. Senate, February 18, 1986.

Dinges, Dav1d, 1987. Testimony before the Subcomnttree on Transportation, Comittee on Appropriations, U.S. Senate, May 14, 1987.

Drew, G.C., W.P. Colguhoun and H.A. Long, 1959. Effect of Small Doses of Alcohol on a Skill Resembling Driving, Her Majesty's Stationary Office, London.

Drory, A., 1985. "Effects of Rest and Secondary Task on S1mulated Truck-Driving Task Performance," Human Factors, Vol. 27, No. 2, pp. 201-207.

Endou, T., M. Ohsh1ma, T. Watanabe and 0. Shingo, 1979. "A Preventive Measure Against Drowsiness While Driving," Ergonomics, Vol. 22, No. 6, p. 758.

Federal. Highway Administration, 1987. Monitoring Operations of Larger Dimension Vehicles, January 14 report. 
Fructus, J., 1987. "H1ghl1ghts on Heavy Vehicle Safety in Europe," Sympostum on the Role of Heavy Frelght Veh1cles in Traffic Accidents, OECD, vol, $1, p$. $1-31$.

General Services Admintstration, 1984. Code of Federal Regulations Transportation, 49, Parts 100 to 177, U.S. Government Printing Office.

Goldman, P., 1986. Vice Chairman, NTSB, Testimony before the Comittee on Commerce, Sclence and Transportation, U.S. Senate, February 18, 1986.

Green, P., et al.., 1980. Accidents and the Nightt1me Conspiculty of Trucks, Untversity of Michigan.

Hackman, R.D., et al.., 1978. Analysis of Accident Data and Hours of Service of Interstate Comercial Motor Vehicle Drivers, prepared for the Federal Highway Administration.

Hamelin, P., 1987. "Truck Drivers' Involvement in Traffic Accidents as Related to their Shiftworks and Professional Features." Symposium on the Role of Heavy Freight Vehicles in Traffic Accidents, OECD, Vol. 2 .

Harr1s, W. and R.R. Mackie, 1972. A Study of the Relationsh1ps Among Fat1gue, Hours of Service, and Safety of Operations of Truck and Bus Drivers, Human Factors Research, Inc.

H1ldebrandt, G., W. Rohmert and J. Rutenfranz, 1974. "12 and 24 Hour Rhythms in Error Frequency of Locomotive Drivers and the Influence of Tiredness," International Journal of Chronoblology, Vol. 2, p. 175-180.

Insurance Institute for H1ghway Safety, 1987. "Radar Detectors Spur Speeding," IIHS Status Report, Vol. 22, No. 3.

Insurance Institute for H1ghway Safety, 1985. Big Trucks.

Jones, I.S, and H.S. Stein, 1988. "Truck Operat1ng Characterfstics in Relation to Safety," ASCE Truck Safety Conference.

Jovan1s, P.0., 1987. "A Perspective on Motor Carrier Safety Issues in the 1980's," presented at the Conference on Truck Safety, Northwestern University.

Karlson, T., et al.., 1977. "Fatally Infured Truck Drivers," Proceedings of the $21 \mathrm{st}$ Conference of the American Association of Automotive Medicine.

Koziol, J.S. and P.H. Mengert, 1978. Rallroad Grade Crossing Passive Signing Study, Report No. FHWA-RD-78-34.

Land1s, R., 1986. Assoclate Administrator for Motor Carrlers, Testimony before the Committee on Commerce, Sclence and Transportation, U.S. Senate, February 18, 1986.

Lees, I.J., 1987. "Nature and Cause of Heavy Freight Vehicle Crashes in Austral1a," Symposium on the Role of Heavy Frelght Vehicles in Traffic Accidents, OECD, Vol. 1, p. 2-57. 
Lipp1ng, H., 1980. Traffic as Work1ng Environment, Transportation Vaestra Vaegen, Sweden.

Mackle, R.R. and J.C. Miller, 1978. Effects of Hours of Service, Regularity of Schedules and Cargo Loading on Truck and Bus Driver Fatigue, Human Factors Research, Inc.

Motor Vehicle Manufacturer's Assoclation, 1985. Motor Truck Research.

National Highway Traffic Safety Administration, 1987. Heavy Truck Safety Study, prepared in response to Motor Carrier Safety Act of 1984 .

National Highway Traffic Safety Administration, 1986. Truck Occupant Protection, prepared in response to Motor Carrier Safety Act of 1984.

National Highway Traffic Safety Administration, 1981a. Nattonal Accident Sampling System (NASS), Analytical User's Manual.

National H1ghway Traffic Safety Administration, 1981b. Fatal Accident Reporting Systems (FARS), User's Guide.

National Transportation Safety Board, 1987. NTSB Heavy Truck Study, presented at the National Motor Carrier Safety Workshop.

National Transportation Safety Board, 1986. Training, Licensing and Qualification Standards for Drivers of Heavy Trucks, Report No. DB86-917001.

National Transportation Safety Boord, 1972. Spectal Study of Tra1n Accidents Attributed to the "Negligence of Employees."

Office of Technology Assessment, U.S. Congress, 1988. Gearing Up for Safety: Motor Carrler Safety.in a Compecitive Environment.

Office of Technology Assessment, U.S. Congress, 1986. Transportation of Hazardous Materlals, OTA-SET-304, U.S. Govermment Printing office.

Olson, P.D., et al., 1984. Parameters Affecting Stopping S1ght D1stance, NCHRP Report No. 270, prepared for the Transportation Research Board.

Oregon Public Ut1l1ty Comm1ss1oner, 1985. 1984 Truck Inspections and Truck Accidents in Oregon.

Paramore, et al., 1979. Human and Physlcal Factors Affecting Collisions, Rammings, and Groundings on Western Rivers and Gulf Intercoastal Waterways, prepared by ORI, Inc. for the U.S. Coast Guard.

Price, H.E., 1987. "Technology and the Man-Machine Interface Effectiveness," presented at the Man-Machine Interface Workshop, Windsor, Ontarto.

Private Line, 1986. "A Driver Incentive Plan with an On-Board Computer Rewards Proper Veh1cle Operation," October, p. 15. 
Ranney, T.A., K. Perchonok and L.E. Pollack, 1984. Identification and Testing of Countermeasures for Specific Alcohol Accident Types and Problems - Volume III: The Heavy Truck Alcohol Problem. Prepared for NHTSA, Report No. HS-806-651.

Regular Common Carrier Conference, 1987. RCCC Motor Carrier Safety Survey, Alexandria, VA.

Re1f, 2.F., T.N. Moore, and A.E. Steevensz, 1980. No1se Exposure of Truck Drlvers, Soclety of Automotive Englneers, Report No. SAE 800278.

Riley, J., 1986. Administrator for the Federal Raflroad Administration, Testimony before the Commlttee on Comerce, Sclence and Transportation, U.S. Senate, February 18, 1986.

Robinson, H., et al., 1969. Trucks in Rural Infury Accldents, prepared for NHTSA, Report No. HS-800-232.

Safety Management Institute, 1978. Analys1s of Accident Data and Hours of Service of Interstate Commerclal Motor Vehicle Drivers, prepared for OMC.

Sanders, M.J., 1980. A Nationwlde Survey of Iruck and Bus Drivers, Canyon Research Group, Inc.

Sheridan, T., 1983. "Measuring, Modeling and Augmenting Reliability in Man-Machine Systems," Automat1ca, 19(6), 637-645.

Solomon, D., 1964. Accldents on Main Rural H1ghways Related to Speed, Driver and Vehicle, U.S. Department of Comerce, Bureau of Public Roads.

Stocker, I.U., 1987. "Stat1stical Analysis of HFV Accidents," Symposium on the Role of Heavy Fre1ght Vehicles in Traff1c Accidents, OECD, Vol. $1, p$. 2-16.

Strandberg, L., 1987. "On the Braking Safety of Articulated Heavy Freight Vehicles," Symposium on the Role of Heavy Freight Vehicles in Iraffic Accidents, OECD, Vol. 2, p. 3-28.

The1s, T., 1987. "Road Frelght Transport Related Aspects Resulting from Deregulatory Actions Within the European Communities: Consequences in the Special Pleld of Road Safety," Symposium on the Role of Heavy Frelght Vehicles In Traffic Accidents, OECD, Vol. 3, p. 4-38.

TR News, 1988. "Rumble Strips Alert Drivers, Save IIves and Money," Transportation Research Board, March-Apr11 Issue, pp. 20-21.

Transportation Research Board, 1987. Zero Alcohol and Other Options: Limfts for Truck and Bus Drivers, Special Report 216.

Troup, J.D.G., 1978. "Drfver's Back Pain and Its Prevention: A Review of the Postural, Vibratory and Muscular Factors, Together With the Problem of Transmitted Road-Shock," Applied Ergonom1cs, Vo1. 9, No. 4, pp. 207-214. 
Tuler, Seth, R.E. Kasperson and S. Ratick, 1988. The Effects of Human Reliability on Risk in the Transportation of Spent Nuclear Fuel, draft final report, prepared by Clark Untversity for the-Nevada Nuclear Waste Project office.

U.S. Coast Guard, 1984. Coding Instructions for the Automated File of Commerclal Vessel Casualties.

W1lson, L.J. and T.W. Horner, 1979. Data Analys1s of Tractor-Tra1ler Drfvers to Assess Drtvers' Perception of Heavy Duty Truck R1de Quality, prepared for NHTSA, Report No. DOT-HS-805-139.

Winkler, C., et al.., 1983. Parametrfc Analys1s of Heavy Duty Truck Dynamic Stability, prepared for the National H1ghway Traffic Safety Administration.

Winsor, J1m, 1987. "Serlous Accldents: Manpower Shortages vs. Driver Quality," Heavy Duty Truck1ng, July, p. 18.

Wyckoff, D.D., 1979. Truck Drivers in Amer1ca, Lexington Books.

Ziskind, R., T. Carlin, M. Axelrod, R.W. Allen and S.H. Schwartz, 1977. Toxic Gases in Heavy Duty Dlesel Truck Cabs, prepared for U.S. DOT, Report No. FHWA-RD-77-139. 
APPENDIX A

HAZARDOUS MATERIAIS TRANSPORTATION INCIDENT/ACCIDENT INFORMAIION SYSTEMS

\section{A. 1 INTRODUCTION}

As concern over the safe transport of hazardous materials continues to 8row, public officials are placing greater emphasis on the ability to conduct analyses of present practices and future policy initiatives. The capability to do this effectively is directly dependent on the quality and avallability of information on previous transport accidents and incidents involving hazardous materials cargo.

The objective of this appendix is to explore the reporting requirements of hazardous materlal transport accidents and incldents, and to determine what use $1 \mathrm{~s}$ and can be made of the information which is collected and stored. As described hereln, hazardous materlals are defined by statute (Hazardous Materials Transportation Act) and by regulation (49 CFR 171.8) as substances and materials in quantities and forms that the Secretary of Transportation has found may pose an unreasonable risk to health and safety, or to property, when transported in commerce (General Services Administration, 1984). The approxtmately 2,400 materials classlfied as such are listed in 49 CFR 172 (Transportation Research Board, 1983).

Inclusive in this list are several substances and wastes classified as "hazardous" In order to coordinate DOT's regulatory program with that of the Environmental Protection Agency (EPA). The primary reason for designatiag these materials $1 \mathrm{~s}$ their long-term effects on health and the environment (National Conference of State Leg1slatures, 1984). For each substance, EPA has established a "reportable quantity" (RQ) which indicates the quantity and concentration of a chemical that could pose a threat of pollution. RQ's for most substances are one pound, although EPA has recently studied the effects of changing the RQ level (ICF, 1985). Packages contalning more than the RQ of the hazardous substance are subject to DOT regulation. DOT regulations also apply to hazardous wastes that are subject to EPA's manifest system under the Resource Conservation and Recovery Act (RCRA).

To carry out the regulatory requirements 1mposed by the Hazardous Materfals Transportation Act (HNTA), the Secretary of Transportation established the Office of Hazardous Materfals Transport (OHMT), which was formerly known as the Materials Transportation Bureau. OHMT is responstble for regulating hazardous materlals transport safety, including all transportation by water, wh1ch 18 promulgated by the U.S. Coast Guard under 46 USC 170 and $391(\mathrm{a})$. OHMT's responsibilities also finclude coordination among the varfous DOT modal administrations and other Federal agencies which are Involved in the transport of hazardous materials.

The source of data for analyzing hazardous material incidents emanates from the reports flled by carrlers and others responsible for reporting to varlous agencles under Federal regulations. Each database potentially applicable to study hazardous materlals transport safety is described separately in the following discussion. A table listing these information sources and the1r relationship appears in the ma1n body of this report. 


\section{A.2 OHMT HAZARDOUS MATERIAL INCIDENT REPORTS (HMIS)}

This database became the centralized Federal system for uniform incident data in 1971. Prfor to that time, hazardous materials regulatory authority was divided among the DOT modal admintstrations. Each agency independently developed criteria reflecting thelr particular needs for data collection and analysis. A wide range of hazardous materlals reporting systems evolved which resulted in redundant reporting, inconsistencies in definition and coverage, and reporting gaps.

A transportation-related incldent is defined as any unintentional release of a hazardous material during transportation, or during loading/unloading or temporary storage related to transportation. Th1s includes releases of hazardous wastes and reportable quant1tfes of hazardous substances discharged during transport (Materials Transportation Bureau, 1980). Every Inc1dent must be reported to OHMT in writing as prescribed in the 49 CFR regulations (Parts 171, 174-177), with the exception of consumer commodities which present only a limited hazard during transportation (ORM-D class), electric storage batterles, and certaln paints and related materials (General Services Administration, 1984). These exceptions were established in 1981, and have decreased the number of reported incidents considerably. The exceptions, however, do not apply to Incidents involving alrcraft or those involving the transport of hazardous waste. The written response must be prepared by the carrier on Form F5800.1 and must be submitted to OHMT within 15 days of discovery of the release (USDOT, 1983). While carrlers are required to report, any interested party may report.

An additional telephone reporting requirement is fmposed on carriers when an incident has resulted in one or more of the following consequences as a direct result of the hazardous material (General Services Administration, 1984):
1. a fatality
2. a serfous infury which requires hospltalization
3. estimated carrier or other property damage exceeds $\$ 50,000$
4. fire, breakage or suspected radioactive contamination occurs involving shipment of radioactive material
5. fire, breakage or suspected contamination occurs involving shipment of etlologic agents
6. a situation exists of such a nature that, in the judgement of the

The telephone report must be communicated 1mediately to the National Response Center (NRC), a center staffed 24 hours a day by the U.S. Coast Guard, but which handles the reporting of all significant hazardous matertals spilis under agreements 1 th DOT and EPA. The National Response Center, established In 1974, provides factlities, comuntcation, Information storage and other needs for coordinating emergency response. NRC has two 24-hour toll-free telephone lines to recelve the notifications, and several other IInes to relay the calls to response agencies that may need to know of the release.

The telephone report must include the following information:

1. name of reporter

2. name and address of carrier represented by the reporter 
3. phone number where the reporter can be contacted

4. date, time and location of the incldent

5. the extent of injuries, if any

6. classification name, and quantities of hazardous materials involved, 1f such information is available

7. type of incident and nature of hazardous tnaterial involvement, and whether a continuing danger to life exists at the scene.

This 1nformation 1s transmitted to the U.S. DOT-Transportation Systems Center every evening, where it is subsequently retained and managed by OHMT.

In many cases, carriers have made their telephone contact with CHEMTREC, a chemical transportation emergency center established in 1971 by the Chemlcal Manufacturers Assoctation. Upon request, CHEMrREC provides referrals to persons at the site of a transportation emergency involving hazardous materlals. Since 1980, CHEMTREC has been officially required to notify the NRC of "signiflcant" hazardous materlals transportalion 1ncidents, those which have, or have the potential for, causing considerable harm to the public or the environment. Despite this cooperative arrangement, a call to CHEMTREC only fulfills the NRC telephone reporting requirements, but 1 toes not fulfill the Federal written reporting requirements.

Although spill reporting is a regulatory requirement, in practice it is handled on a voluntary basis. The incentive for reporting is to avold the possibility of a clvil penalty, or a criminal penalty which can be fmposed if a person knowingly comits an act that violates an HMTA regulation. Civil penalties, which are more common than criminal penalties, can include a liabllity of up to $\$ 10,000$ per violation, or one year imprisonment, or both. Criminal penalties are subject to a fine of uf to $\$ 25,000$ or five years imprisonment, or both.

However, since OHMT has very few inspectors to assure compliance with these reporting requirements, and there is a general shortage of inspectors within the DOT modal administrations, it is basically agreed that the Federal enforcement program does not by itself create an adequate deterrent to reporting violations. It has also been suggested that, even when violaters are penalized, the level of the penalty is insuffictent to deter future violations. The reason 18 that the costs of compliance are greater than those of the 1nfrequent penalties. Thus, some operators may consider penalties to be merely an occasional cost of dolng business (National Conference of State Leg1slatures, 1984).

In support of this cla1m, a recent study conducted by the U.S. Congress, Office of Technology Assessment (OTA) has found that up to and perhaps more than 30-40z of reportable hazardous materlal incldents are never reported (Abkowltz and L1st, 1986). EPA Region 7 offlclals have independently estlmated that only about $10 \%$ of reportable releases under 100 gallons are reported to EPA, the states or the National Response Center, if the substance released is not extremely hazardous; if somebody spllled flve gallons of an extremely hazardous substance, 1t would probably be reported; $90 \%$ of releases over 100 gallons are reported; and $20 \%$ of all PCB releases are reported (ICF, 1985). Transport-related incidents constitute $26 \%$ of the incident reports complled by EPA. 
This information system has also been the subject of considerable criticism from the U.S. General Accounting office for the following reasons (General Services Administration, 1984):

1. OHMT is not receiving reports on all incldents because it relies on voluntary reporting from carriers.

2. Companies lnvolved only in the loading, unloading or storage of hazardous materials (e.g., shippers, freight forwarders) are not required to submit hazardous materlal incident reports.

3. Reports are not required by OHMT for incidents involving hazardous materlals shipped in bulk by water.

4. DOT has elected not to regulate f1rms involved only in intrastate transportation, or require them to submit hazardous materials incident reports.

5. OHMT has no systematic procedure for refining reported data which are incomplete or inaccurate.

6. Due to the time limit on reporting and by soliclting solely the carrier's perspective, the total consequence of an incident can be understated significantly.

Each of these factors works to understate the overall 1mpact of hazardous materials transportation incldents in the United States.

Illustrations of these disparities are noted by GAO and other studies. The GAO selected 30 hazardous material transport 1ncidents between 1976 and 1979 and requested OHMT data on these 1ncidents. OHMT had received reports on only 12 of these incidents. The 18 unreported incidents, according to news reports, resulted in 18 deaths, 9 missing persons, and at least 187 injuries. Concerning damage estimates, NTSB Investigations of five accidents 1nvolving the transport of hazardous materials between 1972 and 1979 estimated the overall damage to be $\$ 42$ militon, as compared to an estimate of $\$ 10.1$ million from OHMT reports (Scanlon, 1983). A more detalled study on non-reporting and mis-reporting conducted by OTA has substantiated these claims (Abkowitz and List, 1986).

Despite the obfections to the HMIS database, in many respects it serves as the most relevant database for conducting hazardous materlals transport incident and safety analysis. The HMIS database is the only on exclusively devoted to hazardous materlals transport incidents, and as such, it includes a number of descriptors which can be used to examine issues in packaging, labeling, cause and public safety, that might not otherwise be possible.

If the deficlencles in the database are accepted as stated, the total volume of hazardous materfals incidents is underestimated. However, for the purposes of derfving distributions of events, causes and consequences, and for some multi-modal comparative analyses, the HMIS database may st11l be representative. The approximately 135,000 records which now comprise the HMIR database may permit comprehensive analysis based on statistical cons1derations.

\section{A. 3 SUPPLEMENTARY DATABASES}

Independent of the OHMT Incident reporting system are several accident reporting systems maintained by various DOT modal administrations. The term 
"accident" refers to a vehicular accldent; most hazardous materials transport incidents are not caused by vehicular accidents (e.g., loose fitting). These reporting systems have been designed to cover all transportation accidents under the jurfsdiction of the respective modal administrations, not just those Involving hazardous materlals. In most cases, however, there are special Identifiers in the reporting format to permit the designation of an accident that involves hazardous cargo. This may be a particularly important form of secondary data, as the accldent reports are usually based on an independent set of reporting procedures from the OHMI procedures, and thus are not subject to the same deficiencies as noted in the OHMT infornation system.

Several sources of Information outside of DOT also exist which, in some fashion, address the subject of incidents and accidents involving the transportation of hazardous materlals.

\section{A.3.1 Modal Administrations}

In addition to coordinating activities with OHMT, the DOT modal administrations conduct their own recordkeeplng procedures for accidents under the1r purview. In many cases, the capability exists to 1solate accidents which Involve the transport of hazardous materlals.

\section{A.3.1.1 U.S. Coast Guard}

The Coast Guard maintains two databases which include recognition of accldents and/or lncidents 1nvolving hazardous materials: (1) Commercial Vessel Casualty File (CVCF), and (2) Pollution Incident Reporting System (PIRS).

The Commerclal Vessel Casualty file Includes vessel accldents (domest1c and forelgn) occurring in U.S. waters which meet one or more of the following reporting criterla:

1. actual physical damage to property in excess of $\$ 25,000$

2. material damage affecting the seaworthiness, maneuverability or efficlency of a vessel

3. stranding or grounding (with or without damage)

4. $108 s$ of life

5. Infury causing any person to remain incapactitated for a period in excess of 72 hours, except infury to harbor workers not resulting in death and not resulting from vessel casualty or vessel equipment casualty.

This data has been collected since 1963, and the only major reporting changes have been a move to an alphanumeric format in 1980, and a change in the damage threshold in August 1982 from $\$ 1,500$ to $\$ 25,000$. Fields in each record 1nclude vessel character1stics, event, cause, fatalities/1njuries and monetary damage. The mafor deficiency in the file is the lack of a commodity classification in the database. However, there are specific vessel codes whlch Indicate whether the vessel was carrying hazardous cargo (U.S. Coast Guard, 1984). 
The PIRS database consists of reports generated as required by FWPCA and CERCLA, It fncludes all polluting spills into U.S. waters, including those occurring during transport. There is a special identification for transport-related spills and materials are 1dentffied by name, so hazardous substance spills during transport can be tracked. The database also includes the quantity released, cause of the incident, and the date and location. In addition, the file contains potential incidents where the Coast Guard was called in, but a sp1ll did not materlalize (U.S. Coast Guard, 1983).

According to Coast Guard officlals, the. PIRS database is rather unrellable, owing to unedited files where major errors often appear. Furthermore, only closed cases are avallable for analysis from the database, so recent cases, those which are tied up in the courts, and cases where the Coast Guard district has neglected to update the flle when a case is closed, are not available and bias any conclusions reached by using the data. The Coast Guard is in the process of designing methods to address these problems.

The Coast Guard databases may be viewed as filling a rather glaring gap in the HMIS database, which is particularly weak in the marine mode. This is due, In part, to the lack of OHMT regulatory enforcement of bulk movements shipped by water.

\section{A.3.1.2 Federal Highway Administration (FHWA)}

FHWA's office of Motor Carriers (OMC) maintains a database on accidents which has been operational since 1973. It 1ncludes any motor carrfer accident in which a fatality or infury occurred, or for which there was at least $\$ 2,000$ in property damage. Reports are filed on Form 50-T, the format of which has remained relatively stable through the years. The OMC database includes carrler identification and address, location of the incident, characteristics of the event, cause, Information on the cargo, and consequences of the accident. The carrier identification, cargo description and certain accident characteristics are such that congruence between the HMIS database and OMC database may be achlevable for 1ncidents caused by vehtcular accidents.

\section{A.3.1.3 Federal Rallroad Administration (FRA)}

FRA maintains its own accident/incident database from information generated by rallroads, Inspectors and OHMT. Although the database goes back before 1974, access to the pre-1974 data 1s rather difficult. The database includes information similar to the accident characteristics described in the Coast Guard and FHWA databases. FRA has its own defintition of incidents and accidents. An incident is an event which results in a death, reportable infury or property damage. If the event results in a death or reportable infury, and damages exceed a threshold of $\$ 4,900$, then the event is classiffed as an accldent. The threshold value has been 1ncreased by FRA over the years to approximate constant real value.

FRA performs a number of internal conslstency checks to strengthen the validity of the database. These include the elimination of double-counting of events when more than one raflroad files a report, spot checks of susplcious events and occastonal audits of rallroad internal records. 
In the past ten years, over 80,000 records have been 1ncluded in the FRA f1le. Approximately 1,000 of these have involved releases of hazardous materials.

FRA also maintains an OEMT enhanced database on hazardous materials incidents. The enhancements include the addition of accident location information, raflroad code and SICC code.*

\section{A.3.1.4 Federal Aviation Administration (FAA)}

The FAA maintains a computerized accident/incident database at their National Fleld office in Oklahoma C1ty which consists of a1r accidents officially reported to NTSB and reports flled by FAA field inspectors. FAA makes a distinction between an "accident" and an "Incident" based on the dollar damage incurred in the reported event. The FAA database includes the pilot involved, the carrier, time-of-day, and other descriptors such as contributing circumstances and accident (incident) severity. It is apparently possible to 1dentify hazardous materials accidents/incidents in this database, for according to FAA officlals, 11 accidents/1nctdents involving hazardous materlals have been reported in the past five years.

\section{A.3.1.5 Natlonal Highway Traffic Safety Administration (NHTSA)}

NHTSA's National Center for'Statistics and Analysis maintains accident data on polfce reported accidents, including those which resulted in non-fatal injury ard/or property damage. The data is typically collected by each state under contractual agreement with NGTSA.

The file of reported accidents is called the National Accident Sampling System (NASS). NASS was developed to provide an automated, comprehensive national traffic accldent database. The accidents Investigated in NASS are a probability sample of all pollce-reported accidents in the U.S. (NHTSA, 1981a). The data collection for a NASS-selected accldent is very 1nvolved, and includes characteristics of the accident, driver, occupants, and vehicle. Although the specific comodicy belng carrled is not described, sufficlent information exists to track accidents which are likely to have contalned hazardous materlals cargo. In fact, recently a hazardous materlals "flag" has been added to the record description. However, outside of the date and location of the accident, there appears to be little or no congruence with the data collected by OBMT. Even so, the characterlstics of the driver, road and traffic may be important determinants of hazardous materials accidents for wich ORMT does not have the approprlate information.

Those accidents which result in loss of human life are also classified separately in the Fatal Accldent Reporting System (FARS). The FARS f1le contains data on vehicles and persons involved in fatal accidents, defined as an event in which an accident-related death occurred within 30 days of the accldent (NHTSA, 1981b). FARS is not a national sample; rather, it 1ncludes all fatal traffic accidents that are reported in the United States. Other than this distinction, however, the information collected parallels the NASS data structure and is subject to the same critique as noted previously.

* Standard Transportation Commodity Code 


\section{A.3.2 Other Useful Databases}

The following information systems may also be useful in analyzing hazardous materlals transport safety. They consist of other Federal agencies state and local agencles, carriers and trade organizations that maintain data on accidents and incidents.

\section{A.3.2.1 National Response Center (NRC)}

Although telephone reports to the National Response Center are primarily intended to stimulate a response action, the information provided in these reports can be used for policy analysis. Data items include the location of the incident, mode of transportation involved, materfal involved, and quantity released. The materlal definitions are coded differently than in the hMIS and causal factors are not considered in any fashion. However, the NRC database does provide a more balanced portfollo of incldents by varlous modes, particularly with regard to marine transport.

\section{A.3.2.2 Environmental Protection Agency}

EPA regional offices have personnel to recelve notffication of releases of hazardous substances. These notifications are integrated into a regional incident reporting system. Typical reports include the incldent date, company Involved, spill location, nature of the emergency, material spilled and volume, source of the sp111, responding agency, nature of the response and resolution. In some EPA reglons, this information is maintained in computerized files.

EPA also recelves the NRC reports and uses this Information in concert with incidents reported to EPA reglonal offlces, states and local governments to formulate regulatory polfcy. Attempts are presently being made to use the NRC reports as a management Information system to support EPA inftlatives.

\section{A.3.2.3 National Transportation Safety Board (NTSB)}

NTSB receives the NRC telephone reports, which they use in determining whether to proceed with an 1nvestigation. NTSB's 1nvestigation of transportation accidents is a multi-modal activity. Their jurisdiction for conducting investigation is based on the definition of a major vehicular accident as defined by each mode in CFR 49.

An NTSB investigation begins wh a multiple-day fleld investigation Involving the shipper, carrler, government agencies, assoctations, and other interested parties. A report is subsequently generated which goes through several cycles of review and comment before it is finalized. The primary purpose of the report is to make recomendations to 1mprove transportation safety based on findings from the accident investigation.

A major advantage of the NTSB process is that the Investigations involve other participants besides the carrier, are extremely thorough, and take place over a longer time frame so that the full impact of the accident can be more accurately 1dentified. As noted by GAO in their critique of the HMIS 
database, the damages reported by the carrier to OHMT often substantially underestimate those reported by NTSB (U.S. GAO, 1980).

NTSB does malntain a database on the vital statistics of each Investlgated accident. Raflroad and avlation accldents are stored in computer flles. Highway and marine accidents are stored on coding sheets, but have not, as yet, been logged into the computer system.

\section{A.3.2.4 Department of Energy (DOE)}

DOE malntains a database on all radioactive incidents, known as the Radloactive Materlals Incldent Reports (RMIR), based on the HMIS file and information from the Nuclear Regulatory Commission on the loss of control of radioactives. The database consists of approximately $70 \%$ HMIS records and $30 \%$ Nuclear Regulatory Comission records. It is on-line, and is maintained by Sandia Labs.

\section{A.3.2.5 Nuclear Regulatory Commission}

Besides the aforementioned activity, the Nuclear Regulatory Comission is the lead agency in conducting investigations of transport accidents involving radioactive materials. These investigations have focused on mechanical analyses of the containers involved in the accident, for the purpose of improving the safety of containers used in transporting radioactive materlals.

\section{A.3.2.6 State and Local Agencies}

Accident/incldent databases maintalned by state and local agenctes vary considerably depending on the authorities involved and the level of comitment that has been made to managing the hazardous materlals transport problem.

Based on Ifmited observation, state and local agencies appear to be more directly involved in accident reporting systems than incident reporting systems and focus much of their attention on the highway mode. This likely is due to the role of the state and local police in reporting traffic accidents, and a more established and coordinated network of accident management. Some states do, however, have mandatory reporting of hazardous substance releases similar to CERCLA requirements although many local agencles are unaware of these reporting requirements (National Conference of State Legislatures, 1984).

There have, however, been state and local attempts to focus on hazardous materlals incidents. Wuch of this activity has been funded by OHMT in the form of demonstration profects to examine hazardous materlals accident prevention and emergency response capabilities.

The first of these projects, completed in 1981, was conducted by the Puget Sound Counc1l of Governments (PSCOG). As part of 1ts study, PSCOG examined hazardous materials movements and incidents within the region. Subsequent profects have been conducted by the State of Massachusetts, the c1t1es of New Orleans, Memphis and Indlanapol1s, the Association of Bay Area Governments (San Franc1sco), and Nlagara County, New York. Wh1le the grantees 
have, In some cases, made efforts to collect incldent data from local sources, often the HMIS database has been accessed to 1dentify 1ncidents which have occurred in the study region (C1ty of Indianapolis, 1983).

More sophisticated applications at the state level center around the use of computerized accident recordkeeping systems in concert with flow data to determine accldent rates and high rlsk locations in the highway network. The states of Utah, Washington and New York, for example, maintain computerlzed accident recordkeepling databases that contain police accident investigation reports. Typically, these reports include, when a heavy-truck is involved, the carrier name, vehicle type, contributing circumstances, accident severtty, etc. In the case of the state of Washington, the type of cargo (United National Code) is also included.

This type of database permits the extraction of heavy vehicle accidents where hazardous cargo was involved (or likely was involved). This information can be portrayed against movement data to determine accident rates of vehicles transporting hazardous cargo, which can subsequently be used in the computation of transport risk profiles and the identiffcation of safer procedures for routing hazardous materlals. Although the capability to do this exists in the states of Washington and New York, the fragmented nature of where accident and movement data reside, and their relationship with the offices responstble for policy analysis have served as constraints. These states are, however, moving in the direction of conducting 1mproved analyses with the data that is collected and maintained.

The State of Maryland has largely overcome these problems. Several years ago, Maryland began a survelliance system of hazardous cargo movements at multiple check points and different times of the day. It also instituted a state incident reporting system where any hazardous material incident resulting in a reported spill is entered into the database. These two sources of Information are subsequently compared to determine the level of hazardous material transport safety in the state. This information has been used to successfully demonstrate a preferred nuclear materials routing system in Maryland. It should be noted that the accomplishments in Maryland have come after cen years of activity and significant coordination among state agencles.

\section{A.3.2.7 Carriers}

Virtually all carriers retaln coples of reports on accidents and incidents that they have filed wth the approprlate authorfties. However, personal contact with a few carriers has shown that the method used for reporting information on Form $F 5800.1$ is rather arbitrary. For example, if the damage is rather small, it is often reported as no damage. Furthermore, when the damage is measurable, the carrlers usually report the out-of-pocket cost, and often include only the loss of cargo and not the clean-up cost.

In fact, beyond the reporting requirement to OHM, there is little evidence that the incident reports are used internally for any analysis purposes, including the safety of operations. The carrlers who were contacted also Indicated that the 15 day reporting requirement is too short and that is inappropriate for the carrier to assume the reporting requirement for loading/unloading incidents since they do not perform this function and of ten are unaware of the incident having occurred or the detalls concerning it. 


\section{A.3.2.8 Assoctation of American Ratlroads (AAR)}

The AAR maintains its own hazardous materials incldent database from inspector, rallroad, F5800.1, CHEMTREC and telephone reports. Information Includes date, incident location, incident type, source of the data, deaths and infuries, and estimated damage. The damage estimates can be segmented by equipment, lading, fire and other damage. The AAR database goes back to 1973.

\section{A.4 REGULATORY USES OF THE DATABASES}

The previously described databases serve a very important purpose for DOT, Its modal administrations, and other agencies in the areas of inspection, enforcement and equipment requirements.

The size of the hazardous materlals regulated comunfty is such that inspection of every facility, manufacturer, shipper, carrier, etc., is infeasible, requiring modal administrations to use a varlety of criteria to determine how best to deploy their finfte inspection resources. As a rule, violation and incident experience are the indicators mose frequently used to 1dentify areas on which to concentrate their inspection efforts. The Coast Guard, for example, has redirected its inspection efforts towards "h1gh-priority" vessels, the definition of which Includes a vessel with a previously reported hazardous materials 1ncident. OMC and FRA also use selection criteria to determine inspection priorities which are based in. part on Incident experfence (USDOT, 1983).

Statistics generated by the hazardous materlals incident databases are also used interrilly to measure program effectiveness, improve prevention by Identifying and analyzing causes and events, and for general regulatory and enforcement analysis. For example, OBMT is interested in the data for regulatory evaluation concerning packaging requirements. OMC uses 1ts database for cargo container analyses. In the case of the railroad industry, DOT has used Incident/accident data to examine contalner specifications for tank cars. This resulted in amendments to CFR 49 that require thermal protection or Insulation against external fire sources, tank-head protection agalnst punctures, coupler modifications to resist disengagement, and other Improvements to be made to new cars or retrofitted to existing equipment used to transport hazardous chemicals under pressure (Public Technology, 1980).

There is reason to belleve that incldent/accldent databases can be used to Improve emergency response and disaster preparedness. For example, knowledge of h1gh accident frequency locations and the flow of hazardous materials provides comonities with a better understanding of the probability of an Incident and the likely materials involved.

There have also been a broad set of requests for both accident and Incident data from the private sector, including legal professionals, industry analysts, private citizens, consultants and university researchers. In most cases, these are handled through distributions of a hard copy of the requested material. Some databases are also accessible through on-line queries via telephone access. 


\section{A.5 SUMMARY}

This appendix has focused on the reporting and data collection of accidents/incldents 1nvolving hazardous material transport. As noted, the regulatory environment has evolved to a point where OHMT should be the repository of Information on hazardous materials transport incidents. Data collected by DOT modal administrations focus more generally on vehicular accidents, yet permit the 1dentification of accldents which involve hazardous materfals. Other databases serve a purpose of identffying either hazardous material transport accidents or 1ncidents. Because of this connectivity capability, the avallability of these "secondary" databases in a supporting role is an invaluable resource.

The HMIS database maintained by OHMT has become the best source of data on the causes, events and consequences surrounding hazardous materials incldents. However, several reporting and data collection deficfencles exist, which make it difficult to conduct unbiased analyses of hazardous materials transport incidents and safety without additional verification. The most useful sources of additional verification appear to be the NRC telephone reports, NTSB investigations database, state and Federal agency accident files, and other related databases.

The NTSB damage estimates and probable causes are likely to be more accurate than those filed by the carrier within 15 days to OHMT. The number of Incidents and accldents 1nvolving hazardous materlals that go unreported to OHMT can be 1dentified, in some respects, by examining accident reports filed to the modal administrations, state agencles and NHTSA, and Incident reports filed with NRC, and comparing them to incidents reported in the HMIS file (even after this process, the number of unreported events may still be significant). Th1s is particularly 1mportant in the case of the marine mode, where reports on incidents 1nvolving hazardous materials transported in bulk are not requested by OHMI.

Although the additional sources of 1nformation are extremely important, in practice it is quite difficult to establish congruence among any of the databases. Th1s 13 due to several reasons, the most 1mportant of which are different definitions of accidents and incidents, criterla for a reportable event, ability to track a hazardous cargo movement, and level of detall concerning spectific commodity, contributing factors, consequences, etc. Thus, the secondary data is not an adequate substitute for an 1mproved primary information system.

A number of suggestions have been made to 1mprove the accuracy and completeness of hazardous materlals incident reporting. These recommendations focus on the contents of the incident report form, criterla and procedures for incident notification, and internal management of reported information (Abkowltz and L18t, 1986).

For example, Form F5800.1 can be modified in format so that it is more standardized and does not allow for too much flexiblifty in response that has led in the past to incomplete reports and subfective judgments of OHMT data entry clerks. This would also simplify the data entry process, and diminish the likellhood of redundant codes allowable for the same data entry field. The amount of information required on Form F5800.1 does not appear to be excessive when contrasted with other incident/accident reporting systems, and 
could actually be expanded to include a few additional characteristics of the incident, if desired.

OHMT should remove the "voluntary" notion of incident reporting via policy inftiative and/or new leglslation requiring mandatory reporting of incidents meeting the reporting criterla. In order to enforce more stringent requirements, the penalties for non-compliance must be 1ncreased substantially in severity. In response to 1ssues ralsed by carriers, it would be beneficial to extend the reporting limlt beyond 15 days, and perhaps shippers and receivers should also be required to file written reports when incidents involve loading/unloading operations.

Finally, OHMT management should focus intemally on improving the completeness of flled reports, 1dentifylng and medlating mis-reporting, and identifying and prosecuting non-reported 1ncidents which meet the OHMT reporting criterla. This requires the cooperation of other government agencles in the form of data sharing and perhaps minor modification to their own reporting practices.

None of these recommendations are resource-1ntensive; in some cases, only one time developmental expenses would be 1ncurred. In Iight of the inadequacies in the present information system, this is a relatively Inexpensive program for establishing a comprehensive basis for monttoring and regulating safety in the hazardous materlals transport industry. 


\section{A. 6 REFERENCES}

Abkowtz, Mark and George "L1st, 1986. Hazardous Materlals Transportation: Commodity Flow and Incident/Accident Information Systems, Final Report, prepared for Office of Technology Assessment.

City of Indlanapolis - Emergency Management Div1sion, 1983. Demonstration Project to Develop A Reglonal Hazardous Materials Accident Prevention and Emergency Response Program.

General Services Adminfstration, 1984. Code of Federal Regulations Transportation, 49, Parts 100 to 177, U.S. Government Printing Office.

ICF, Inc., 1985. Economfc Analys1s of Reportable Quantity Adjustments Under Sections 102 and 103 of the Comprehens1ve Environmental Response, Compensation and Liability Act.

Materials Transportation Bureau, 1980. Gulde for Preparing Hazardous Materlals Incident Reports, USDOT-RSPA.

National Conference of State Leg1slatures, 1984. Hazardous Matertals Transportation: A Legislator's Gulde.

NHTSA, 1981a. National Acc1dent Sampling System (NASS), Analytical User's Manual.

NHTSA, 1981b. Fatal Acc1dent Report1ng Systems (FARS), User's Gu1de.

Publ1c Technology, Inc., 1980. Transportation of Hazardous Materials.

Scanlon, Raymond D., 1983. A Reglonal Study on Hazardous Materials Iransportation, Howard S. Cullman Fellowship Report.

Transportat1on Research Board, 1983. Transportation of Hazardous Materfals: Toward a National Strategy, Volume 1, special Report 197.

U.S. Coast Guard, 1984. Coding Instructions for the Automated F1le of Commercial Vessel Casualties.

0.S. Coast Guard, 1983. Polluting Incldents In and Around U.S. Waters, Calendar Year 1981 and 1982.

U.S. Department of Transportation - RSPA, 1983. A Gulde to the Federal Hazardous Materials Transportation Regulatory Program.

D.S. General Accounting offlce, 1980. Programs for Ensuring the Safe Transportation of Hazardous Materlals Need Improvement. 